\title{
EVOLUÇÃO DIFERENCIADA ENTRE OS ESTADOS BRASILEIROS DO CULTIVO E DO PROCESSAMENTO INDUSTRIAL DA SOJA - PERÍODO DE 1970 A 1999
}

\section{ALESANDRA BASTIANI DOS SANTOS}

Economista

Orientador: Prof. Dr. CARLOS JOSÉ CAETANO BACHA

Dissertação apresentada à Escola Superior de Agricultura "Luiz de Queiroz", Universidade de São Paulo, para obtenção do título de Mestre em Ciências, Área de Concentração: Economia Aplicada.

P I R A C I C A B A

Estado de São Paulo - Brasil

Agosto - 2000 


\section{ERRATA}

No que se refere a introdução da cultura da soja no Brasil, páginas 1 e 8 , há autores que assinalam que esta cultura foi introduzida no final do século XIX, mais especificamente em 1882 no Estado da Bahia, e outros que relatam que a mesma foi introduzida no início do século XX. Cabe ressaltar que o registro feito na página 8 está de acordo com Zockun (1980).

\begin{tabular}{|c|c|c|}
\hline Localização & Onde está & Deve ser \\
\hline Página iii, $3^{\circ}$ parágrafo, $1^{\circ}$ linha & ...Alexandre Laóz... & ...Alexandre Lahóz... \\
\hline Página iv, $5^{\circ}$ parágrafo, $2^{\circ}$ linha & ...equilíbio... & ...equilíbrio... \\
\hline Página $1,3^{\circ}$ parágrafo, $4^{\mathrm{o}}$ linha & ...localizavam-se... & ...localizam-se... \\
\hline Página 19, nota de rodapé, $1^{9}$ linha & ...propriedade pequena pequena... & ...propriedade pequena... \\
\hline Página $26,1^{\underline{0}}$ parágrafo, $1^{0}$ linha & ...discriminado... & ...discriminados... \\
\hline Página $55,1^{\circ}$ parágrafo, $4^{\circ}$ linha & ...Estado do Bahia. & ...Estado da Bahia. \\
\hline Página $57,1^{\circ}$ parágrafo, $9^{\circ}$ linha & ...1985 De modo... & ...1985. De modo... \\
\hline
\end{tabular}




\title{
Dados Internacionais de Catalogaçäo na Publicação (CIP) DIVISÃO DE BIBLIOTECA E DOCUMENTAÇĀO - Campus "Luiz de Queiroz"/USP
}

\author{
Santos, Alesandra Bastiani dos. \\ Evolução diferenciada entre os estados brasileiros do cultivo e do processamento \\ industrial da soja - periodo de 1970 a 1999 / Alesandra Bastiani dos Santos. - - \\ Piracicaba, 2000. \\ $98 \mathrm{p}$. \\ Dissertação (mestrado) - - Escola Superior de Agricultura Luĭz de Queiroz, 2000. \\ Bibliografia. \\ 1. Análise fatorial 2. Indústria agricola 3. Processamento 4. Soja I. Titulo
}

CDD 338.17334

"Permitida a cópia total ou parcial deste documento, desde que citada a fonte -0 autor: 
Aos meus pais Sidney Bastiani dos Santos e Irene Lubachevski Santos, que deram asas ao meu vôo, através do seu imensurável amor, me incentivando nos momentos mais difíceis e compartilhando todas as conquistas. 


\section{AGRADECIMENTOS}

A felicidade é uma benção de Deus, e quase sempre uma conquista. E, a felicidade nesse momento consiste nessas duas coisas: na benção de Deus e na conquista pessoal e profissional, e esta última, certamente, deve-se a muitas pessoas.

Ao professor Carlos José Caetano Bacha, pela orientação dedicada e competente, pela paciência, contribuindo não só para a realização desta pesquisa mas também para minha formação profissional.

Aos professores Rodolfo Hoffmann e Alexandre Laóz Mendonça de Barros, contribuindo com críticas e sugestões, enriquecendo, dessa maneira, o conteúdo desta pesquisa.

Ao pesquisador da Embrapa Soja, Antonio Carlos Roessing, pelo imensurável apoio e motivação, pela qualidade de suas observações, estando sempre presente no decorrer deste curso e pesquisa.

Aos amigos Heveraldo Camargo Mello, Carlos Roberto Ferreira, Rossana Lott Rodrigues e Antonio Carlos Moretto que sempre estiveram ao meu lado, através de incentivo, de conselhos e, sobretudo, de carinho.

À professora Zilda P. B. Mattos pela confiança e amizade demostrada.

Aos professores do Departamento de Economia, Administração e Sociologia, pelos ensinamentos recebidos.

Aos amigos Carla R. Freire, Cassiana N. Neris, Edson C. Bignotto (Sbo), Dalton R. S. Leite e Cintia Leite, Denise Rissato, Márcia Istake, Maria Goreth S. Nery e Moizéis S. Nery, Paulo C. Martins, Rudimar A. Cherubin, Yaskara M. Raimundo e Zilmar S. Souza, com os quais fui presenteada por Deus, obrigado pelo carinho, atenção, companheirismo e momentos felizes. 
Aos demais colegas de pós graduação pelo convívio durante o curso.

Aos colegas Marcos M. Hasegawa, pela disponibilidade e paciência em me ensinar trabalhar com o SAS, e Francisco Casimiro Filho, pela atenção e carinho.

Aos funcionários do Departamento de Economia, Administração e Sociologia, em especial: Maielli, Pedro, Luciane, Ligiana, Valdeci e Maria Helena, pela colaboração em todos os momentos do curso.

Ao CNPq pela ajuda financeira.

Ao psicólogo Joãodenir Furlan que me ajudou a enfrentar as dificuldades com maior equilíbio, a amenizar a saudade de casa, enfim, a conviver melhor; e a atenção e carinho da secretária Sueli P. Soares.

À querida Tia Marena (Maria Machula) que sempre esteve presente através do seu amor.

Por fïm, a todas as pessoas envolvidas na realização desta pesquisa. 


\section{SUMÁRIO}

Página

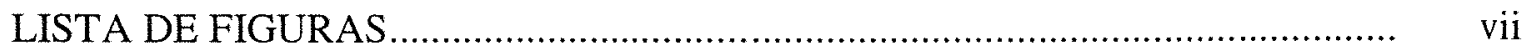

LISTA DE TABELAS ............................................................................. ix

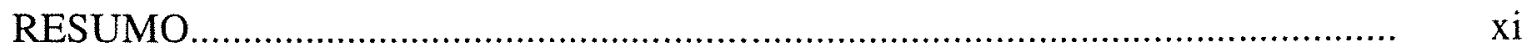

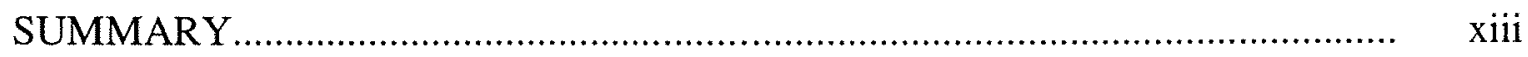

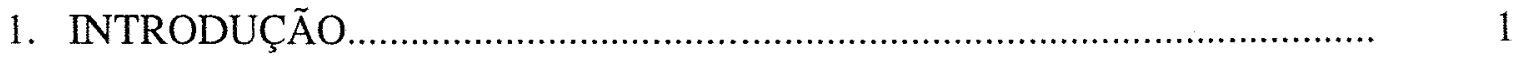

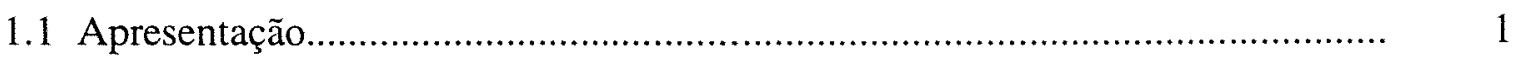

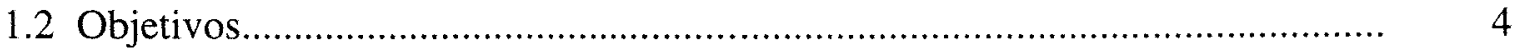

1.3 Hipótese .................................................................................... 5

1.4 Revisão de Literatura................................................................... 5

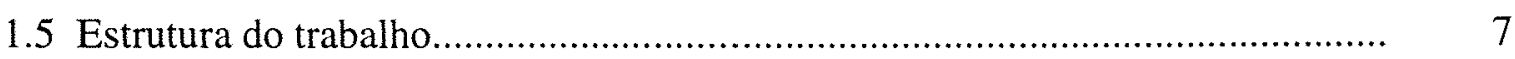

2. EVOLUÇÃO DA CULTURA E DO PROCESSAMENTO INDUSTRIAL

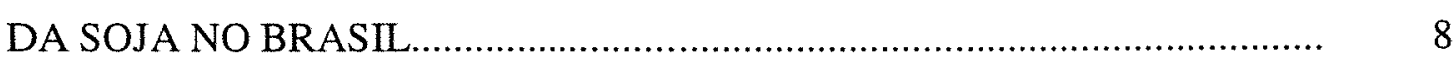

2.1 Evolução da cultura da soja........................................................... 8

2.1.1 Alguns aspectos da comercialização da soja........................................... 15

2.1.2 Tamanho da lavoura e uso de tecnologia na sojicultura............................. 18

2.2 A agroindústria processadora........................................................... 24

2.2.1 O papel da agroindústria processadora de soja no desenvolvimento tecnológico desta cultura.................................................................. 24

2.2.2 A evolução da indústria processadora da soja....................................... 29

3 METODOLOGIA E FONTE DOS DADOS ............................................... 37

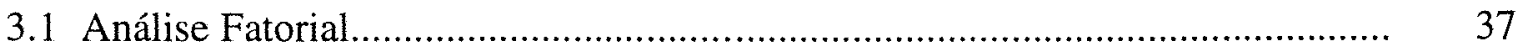

3.2 Indicadores e fonte de dados................................................................ 43

4 MEDIDAS DO GRAU DE MODERNIZAÇÃO DA LAVOURA DA SOJA .... 46

4.1 Notas sobre os indicadores referente à lavoura da soja.............................. 46

4.2 Resultados da Análise Fatorial................................................................ 49

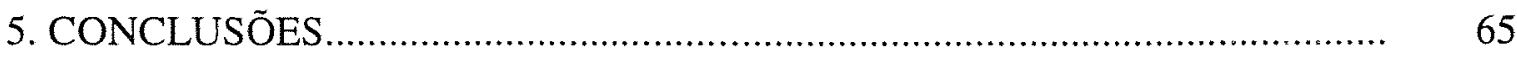

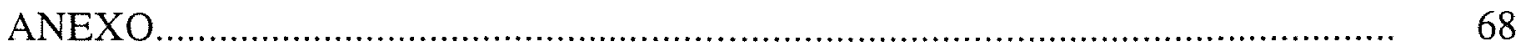




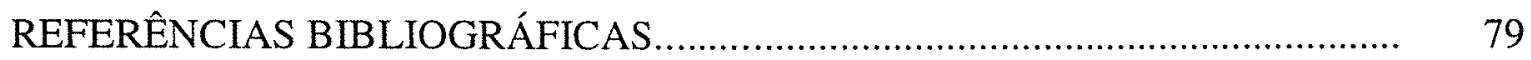

APÊNDICE 


\section{LISTA DE FIGURAS}

Página

1. Evolução da produção de soja em regiões do Brasil de 1970 a 1999.................. 10

2. Participação das regiões do Brasil na produção de soja em 1980....................... 12

3. Participação das regiões do Brasil na produção de soja em 1989........................ 13

4. Participação das regiões do Brasil na produção de soja em 1999 ....................... 14

5. Evolução da produtividade da cultura da soja nos estados da Região Tradicional - 1970 a 1999.

6. Evolução da produtividade da cultura da soja nos estados da Região CentroOeste e MG - 1970 a 1999

7. Evolução da produtividade da cultura da soja nos estados da Região Nordeste -1970 a 1999.

8. Evolução do Fator 1 e Fator 2 para o Estado do Rio Grande do Sul de 1975 a 1995.

9. Evolução do Fator 1 e Fator 2 para o Estado de Santa Catarina de 1975 a 1995

10. Evolução do Fator 1 e Fator 2 para o Estado do Paraná de 1975 a 1995.

11. Evolução do Fator 1 e Fator 2 para o Estado de São Paulo de 1975 a 1995....... 57

12. Evolução do Fator 1 e Fator 2 para o Estado de Mato Grosso de 1980 a 58 1995

13. Evolução do Fator 1 e Fator 2 para o Estado de Mato Grosso do Sul de 1975 a 1995.

14. Evolução do Fator 1 e Fator 2 para o Estado de Goiás de 1975 a 1995.

15. Evolução do Fator 1 e Fator 2 para o Estado de Minas Gerais de 1975 a 1995.

16. Evolução do Fator 1 e Fator 2 para o Estado da Bahia de 1975 a 1995.

17. Evolução do Fator 1 e Fator 2 para o Estado do Maranhão de 1980 a 1995......

18. Evolução do Fator 1 e Fator 3 para o Estado do Rio Grande do Sul de 1975 a 1995

19. Evolução do Fator 1 e Fator 3 para o Estado de Santa Catarina de 1975 a 
1995

20. Evolução do Fator 1 e Fator 3 para o Estado do Paraná de 1975 a 1995............ 59

21. Evolução do Fator 1 e Fator 3 para o Estado de São Paulo de 1975 a 1995....... 59

22. Evolução do Fator 1 e Fator 3 para o Estado do Mato Grosso de 1980 a 1995.

23. Evolução do Fator 1 e Fator 3 para o Estado do Mato Grosso do Sul de 1975 a 1995.

24. Evolução do Fator 1 e Fator 3 para o Estado de Goiás de 1975 a 1995.

25. Evolução do Fator 1 e Fator 3 para o Estado de Minas Gerais de 1975 a 1995

26. Evolução do Fator 1 e Fator 3 para o Estado da Bahia de 1975 a 1995.

27. Evolução do Fator 1 e Fator 3 para o Estado do Maranhão de 1980 a 1995......

28. Evolução do Fator 2 e Fator 3 para o Estado do Rio Grande do Sul de 1975 a 1995.

29. Evolução do Fator 2 e Fator 3 para o Estado de Santa Catarina de 1975 a 1995.

30. Evolução do Fator 2 e Fator 3 para o Estado do Paraná de 1975 a 1995.

31. Evolução do Fator 2 e Fator 3 para o Estado de São Paulo de 1975 a 1995.

32. Evolução do Fator 2 e Fator 3 para o Estado de Mato Grosso de 1980 a 1995

33. Evolução do Fator 2 e Fator 3 para o Estado de Mato Grosso do Sul de 1975 a 1995

34. Evolução do Fator 2 e Fator 3 para o Estado de Goiás de 1975 a 1995.

35. Evolução do Fator 2 e Fator 3 para o Estado de Minas Gerais de 1975 a 1995.

36. Evolução do Fator 2 e Fator 3 para o Estado da Bahia de 1975 a 1995.

37. Evolução do Fator 2 e Fator 3 para o Estado do Maranhão de 1980 a 1995......

38. Desempenho da lavoura da soja entre os estados brasileiros em 1995 


\section{LISTA DE TABELAS}

Página

1. Percentual da produção total da soja que foi entregue às cooperativas estados das Regiões Tradicional, Centro-Oeste e Minas Gerais, e Nordeste anos selecionados

2. Percentual da produção total da soja que foi entregue às indústrias - estados das Regiões Tradicional, Centro-Oeste e Minas Gerais, e Nordeste - anos selecionados

3. Percentual da produção total da soja que foi entregue aos intermediários estados das Regiões Tradicional, Centro-Oeste e Minas Gerais, e Nordeste anos selecionados

4. Distribuição da área cultivada com soja na Região Tradicional em três estratos de área das lavouras de soja - anos selecionados (valores percentuais)

5. Distribuição da área cultivada com soja na Região Centro-Oeste e Minas Gerais em três estratos de área das lavouras de soja - anos selecionados (valores percentuais)

6. Distribuição da área cultivada com soja na Região Nordeste em três estratos de área das lavouras de soja, em 1995 (valores percentuais).

7. Proporção da área colhida de soja que utilizou adubação e defensivos em relação a área total cultivada com soja em cada estado da Região Tradicional - anos selecionados (valores em percentuais)

8. Proporção da área colhida de soja que utilizou adubação e defensivos em relação a área total cultivada com soja em cada estado da Região CentroOeste e Minas Gerais - anos selecionados (valores em percentuais)

9. Proporção da área colhida de soja que utilizou adubação e defensivos em relação a área total cultivada com soja na Bahia e Maranhão em 1995 (valores em percentuais) 
10. Desembolsos do BNDES para o processamento de soja - 1990 a 1997 (em US\$ mil)

11. Percentual de limites livres de descontos ao produtor segundo fator de qualidade.

12. Percentual da capacidade de esmagamento de oleaginosas no Brasil de acordo com o tamanho da planta (somente plantas ativas) - anos selecionados

13. Capacidade de esmagamento de oleaginosas para a Região Tradicional, a Região Centro-Oeste e Minas Gerais, e a Região Nordeste - anos selecionados

14. Indicadores de concentração na indústria de esmagamento de oleaginosas no Brasil - anos selecionados.

15. Economias de escala no processamento de soja: redução de custos esperada de acordo com o aumento no tamanho da planta

16. Matriz de dados para a Análise Fatorial.

17. Valores das raízes características.

18. Cargas fatoriais de 3 fatores e comunalidades na análise dos 12 indicadores relacionados à cultura de soja na Região Tradicional, na Região Centro-Oeste e Minas Gerais, e na Região Nordeste do Brasil, anos selecionados.

19. Valores dos três fatores de relacionados à cultura da soja na Região Tradicional, na Região Centro-Oeste e Minas Gerais, e na Região Nordeste do Brasil - anos selecionados. 


\title{
EVOLUÇÃO DIFERENCIADA ENTRE OS ESTADOS BRASILEIROS DO CULTIVO E DO PROCESSAMENTO INDUSTRIAL DA SOJA - PERÍODO DE 1970 A 1999
}

\author{
Autora: ALESANDRA BASTIANI DOS SANTOS \\ Orientador: Prof. Dr. CARLOS JOSÉ CAETANO BACHA
}

\section{RESUMO}

Este trabalho analisa a evolução da cultura da soja e de seu processamento industrial no Brasil entre 1970 e 1999. A cultura da soja e a indústria processadora apresentam diferentes fases de expansão entre os estados brasileiros: iniciou seu desenvolvimento na Região Tradicional (Rio Grande do Sul, Santa Catarina, Paraná e São Paulo), expandindo-se depois para a região dos cerrados, destacando-se o CentroOeste do País (Mato Grosso, Mato Grosso do Sul e Goiás) e Minas Gerais, e, mais recentemente para a Região Nordeste (Bahia e Maranhão). Para caracterizar essa evolução foram abordados aspectos relacionados com a utilização de insumos, tamanho médio da lavoura, canal de comercialização, atuação da indústria processadora e políticas governamentais de estímulo ao desenvolvimento da cultura.

Partindo dessas variáveis foi mensurado o grau de modernização da lavoura da soja e de outros indicadores referentes a esta atividade, tendo como referência os anos de 1975, 1980, 1985 e 1995. Para tanto, a metodologia utilizada foi a análise fatorial, pelo método dos componentes principais, aplicada a doze variáveis para cada estado das regiões Tradicional, Centro-Oeste e Minas Gerais, e Nordeste. Foram considerados três fatores os quais refletem a importância da lavoura e da capacidade instalada de processamento da soja, a modernização da lavoura da soja, e a utilização de crédito para cada hectare da cultura da soja. 
Os resultados da análise fatorial evidenciaram que a Região Centro-Oeste e Minas Gerais é a que possui os níveis mais altos de modernização da lavoura da soja. No entanto, a Região Tradicional ainda detém a maior concentração da lavoura e capacidade instalada de processamento da soja. Mesmo tendo apresentado reduções da cultura e do processamento industrial da soja no período de 1975 a 1995 (valor do Fator 1), decorrente da expansão para a região dos cerrados, a Região Tradicional continuou se modernizando tecnicamente. A Região Nordeste, mesmo representando uma pequena participação na produção nacional de soja, apresentou altos níveis de modernização da lavoura para o ano de 1995, destacando-se o Estado da Bahia. Esta evolução diferenciada da lavoura da soja entre os estados se explica, em parte, pelas distintas condições edafo-climáticas, disponibilidade de terra e infra-estrutura dos estados.

O trabalho se encerra ressaltando que essa evolução diferenciada da lavoura e do processamento industrial da soja entre os estados sugere a necessidade de políticas públicas diferenciadas para manter ou aumentar a competitividade da sojicultura. 


\title{
DISTINCT EVOLUTION OF SOYBEAN CULTIVATION AND INDUSTRIAL PROCESSING AMONG BRAZILIAN STATES - PERIOD FROM 1970 TO 1999
}

\author{
Author: ALESANDRA BASTIANI DOS SANTOS \\ Adviser: Prof. Dr. CARLOS JOSÉ CAETANO BACHA
}

\section{SUMMARY}

This work aimed to analyze the evolution of soybean cultivation and its industrial processing throughout Brazil from 1970 to 1999. The soybean crop and its processing industry present different phases of expansion among Brazilian states. Their development began in the Traditional Region (Rio Grande do Sul, Santa Catarina, Paraná and São Paulo), and lately expanded to the "cerrado" region, especially to the Middle West of the country (Mato Grosso, Mato Grosso do Sul and Goiás) and Minas Gerais State. More recently, they have expanded toward the Northeast Region (Bahia and Maranhão). In order to characterize this evolution, aspects related to the use of agricultural raw materials, average size of the crop field, commercialization channel, the processing industry actions and the governmental policies to stimulate crop development were approached.

Considering such variables, the level of modernization of the soybean crop and other indicators related to this activity were evaluated, having the years 1975, 1980, 1985 and 1995 as references. To perform this evaluation, the methodology employed was the factor analysis, using the main component method, applied to twelve variables for each state of the following regions: Traditional, Middle West and Minas Gerais, and Northeast. Three factors were considered, which reflect the importance of the soybean crop and the existent potential for soybean processing, the modernization of the soybean crop and the use of agricultural credit for each hectare of soybean culture. 
The results of the factorial analysis pointed out that the Middle West and Minas Gerais Regions are the ones that present the highest levels of modernization concerning the soybean crop. However, the Traditional Region holds the highest concentration of soybean crop, as well as the highest existent potential for soybean processing. Even showing a decrease in the soybean cultivation area and processing within the period from 1975 to 1995 (value of Factor 1), due to the expansion toward the "cerrado" region, the Traditional Region continued modernizing itself technically. The Northeast Region, despite having a small representation in the national soybean production, presented a high level of crop modernization in 1995, with Bahia State standing out. Such distinct evolution of the soybean crop among the states is partly explained by the different edaphic-climatic conditions, soil availability and infrastructure of each state.

To sum up, this work finishes pointing out that this distinguishable soybean crop and industrial processing evolution among states suggests the need of special public policies to maintain or increase the competitiveness of the soybean culture. 


\section{INTRODUÇÃO}

\subsection{Apresentação}

Este trabalho analisa a evolução do cultivo e do processamento industrial da soja nos estados brasileiros no período de 1970 a 1999, destacando os aspectos que diferenciam esta evolução nas unidades da federação.

Dada a importância econômica da cultura da soja, tanto na obtenção de divisas, por representar em torno de $10 \%$ das receitas de exportação ${ }^{1}$, quanto no fornecimento interno de alimentos (óleo de soja, e sua importância para outros setores como o de carnes), torna-se importante a realização de estudos sobre a evolução de sua produção e seu processamento industrial. Estes estudos podem evidenciar pontos que permitam elaborar políticas visando o aumento da eficiência na produção e industrialização da soja.

A soja foi introduzida no Brasil no início desse século e, a partir da década de 70, vem apresentando crescimento da produção associado a mudanças na localização geográfica da concentração das unidades produtivas. Os primeiros estados produtores localizavam-se na Região Sul do Brasil. A partir do início dos anos 80 há maior expansão da produção para a região dos cerrados, em especial para a Região CentroOeste do País. Em meados dos anos 80 e início da década de 90, pode-se observar uma pequena, mas importante, expansão da produção no nordeste, destacando-se os Estados da Bahia e Maranhão.

\footnotetext{
${ }^{1}$ Considerando a participação do complexo soja que compreende o grão, farelo e óleo bruto.
} 
O cultivo da soja iniciou-se no Estado do Rio Grande do Sul e na década de 50 já se tornava uma importante cultura no Estado. No Estado do Paraná o cultivo iniciou-se no ano de 1952. A Região Tradicional na produção de soja inclui também os Estados de Santa Catarina e São Paulo.

Mesmo apresentando uma forte expansão frente às demais culturas nos estados do Rio Grande do Sul e do Paraná, a cultura da soja foi inexpressiva até o fim da década de 60. Até essa década, o crescimento - não somente da cultura da soja, mas de toda agricultura brasileira - esteve relacionado com a expansão da fronteira agrícola. Com a pouca atuação da política econômica para estimular a agricultura, juntamente com a falta de investimentos em pesquisa, os aumentos na produção eram decorrentes, principalmente, do uso crescente da terra e mão-de-obra, ou seja, do aumento de área cultivada mais do que do aumento da produtividade.

A década de 70 foi marcada por um crescimento expressivo da produção de soja, passando de um milhão e meio de toneladas em 1970 para 15 milhões de toneladas em 1980. Ao considerar o período de 1970 a 1979, apesar das frustrações de safras ocorridas em 1977-78 e 1978-79, decorrentes de fortes estiagens, verifica-se que a taxa anual de crescimento da produção na Região Tradicional foi de $24,28 \%$. Esse crescimento pode ser atribuído ao aumento da área destinada a essa cultura, a qual apresentou crescimento médio de $22,25 \%$ ao ano. A produtividade, para esse mesmo período, teve crescimento médio anual de $1,66 \%^{2}$.

Entre as condições que propiciaram o desenvolvimento da cultura da soja, na década de 70, destacam-se as oportunidades apresentadas no mercado externo e a política agrícola incentivando a produção, através de créditos subsidiados para a atividade.

\footnotetext{
${ }^{2}$ Essas taxas foram calculadas a partir de dados anuais de área, produção e produtividade, usando a regressão $\ln Y=a+b t$, onde $Y$ é a área, produção ou rendimento.
} 
A intensidade da expansão da agricultura na região dos cerrados iniciou-se entre o final da década de 60 e início dos anos 70, a partir de incentivos governamentais. Tal desenvolvimento regional tinha como objetivo abastecer os centros urbanos, fornecer matérias-primas para indústrias das áreas mais desenvolvidas do país e aumentar as exportações de produtos não tradicionais, através do aumento da produção e produtividade nas atividades agropecuárias. O suporte para o aumento da produção e da produtividade foi fornecido por meio de programas e projetos de desenvolvimento das atividades agropecuárias e pelo crédito rural (Roessing \& Guedes, 1993).

A evolução da cultura da soja na década de 80 , quando se teve menos subsídios à agricultura do que na década anterior, foi marcada pelo avanço na Região Centro-Oeste do país e no Estado de Minas Gerais. Entre 1980 e 1989 a taxa média de crescimento da produção de soja nessa região foi de $18,63 \%$, resultado de um acréscimo médio anual da área de $15,55 \%$ e de $2,65 \%$ da produtividade. Esse crescimento torna-se mais ilustrativo ao observar que, nessa região, a área cultivada com soja em 1980, de 1,2 milhão de hectares (e produção de 2,2 milhões de toneladas em 1980) passou em 1989 para 5,1 milhões de hectares (com uma produção de 10,5 milhões de toneladas).

Na década de 90 (marcada pela redução dos financiamentos governamentais destinados à agricultura) ocorreu a expansão da cultura da soja nas Regiões Tradicional, Centro-Oeste e Minas Gerais, e Nordeste do País, sendo os Estados da Bahia e Maranhão os mais recentes nessa expansão.

A expansão da cultura da soja proporcionou o fortalecimento de outros setores agroindustriais, como o de carnes, a partir do aumento na oferta de matéria-prima. Esse aumento na oferta interna de soja e a facilidade de comercializar o grão, internamente ou para exportação, ampliaram significativamente as atividades das cooperativas e traders (Paula \& Favaret Filho, 1998).

Segundo Souza (1990, p.176), “a história recente da agricultura brasileira é marcada por uma série de características importantes como a sua integração crescente 
com os setores industriais e financeiros e a modernização da sua base técnica. Isto ocorre sem ainda modificar os desníveis de desenvolvimento em relação a produtos e regiões”.

A expansão da produção da soja no território brasileiro é um fator preponderante na localização das plantas industriais e na capacidade instalada de processamento (Magalhães, 1998).

Do exposto acima, observa-se que há três fases na expansão da cultura da soja no Brasil, que se associam com a mudança geográfica das áreas mais dinâmicas. Neste contexto, algumas indagações ainda persistem, como:

- o padrão tecnológico agrícola das novas áreas cultivadoras e processadoras de soja é diferente da existente em áreas tradicionais?

- como tem evoluído a tecnologia utilizada no cultivo da soja nas áreas tradicionais?

\subsection{Objetivos}

O objetivo geral deste trabalho é analisar a evolução do cultivo e do processamento industrial da soja nos estados brasileiros no período de 1970 a 1999 , observando os aspectos que evidenciam uma evolução diferenciada.

Como objetivos específicos, procura-se caracterizar, através da análise tabular e gráfica, a evolução da lavoura e do processamento industrial da soja no Brasil e em suas regiões; e, obter algumas medidas do grau de modernização da lavoura da soja nos estados brasileiros, através da análise fatorial utilizando o método dos componentes principais. Procura-se verificar, também, como essa modernização relacionou-se com a concentração, em cada estado, da indústria processadora de soja, com a especialização do estado na atividade sojicultora e com as políticas de estímulo à lavoura de soja.

O período a ser estudado, 1970 a 1999, apresenta três fases de novos estados contribuindo ao crescimento da produção da soja no Brasil. De 1970 a 1979, expansão na Região Tradicional; de 1980 a 1989, expansão na região dos cerrados, considerando a 
Região Centro-Oeste e o Estado de Minas Gerais; e, de 1990 a 1999 as novas regiões de expansão da produção são os Estados da Bahia e Maranhão (além da continuidade da expansão nas demais regiões). A expansão da indústria processadora de soja também será analisada considerando a expansão geográfica observada na produção da soja.

\subsection{Hipótese}

A hipótese a ser considerada neste estudo é que por ter condições edafoclimáticas, disponibilidade de terras e infra-estrutura distintas, o cultivo e a agroindústria da soja vêm apresentando evolução diferente nos estados brasileiros.

\subsection{Revisão de Literatura}

A revisão bibliográfica realizada compreende três abordagens importantes para a caracterização da presente dissertação: trabalhos sobre o setor agroindustrial da soja; trabalhos referentes à evolução diferenciada da produção e/ou da indústria da soja; e, trabalhos econométricos tendo a análise fatorial, pelo método dos componentes principais, como metodologia de estudo.

Stülp \& Plá (1993), Rizzi \& Paula (1996), Lazzarini \& Nunes (1997), Magalhães (1998) e Favaret Filho \& Paula (1998) abordam os principais fatores que afetam a produtividade do setor agroindustrial da soja no mercado interno e dos derivados da soja no mercado internacional. Como principais limitantes à competitividade do setor no mercado internacional estes autores ressaltam: capacidade ociosa existente nas indústrias processadoras, distorções tarifárias, baixa produtividade da soja brasileira em relação aos principais países competidores, o crescimento de produtos substitutos como palma, colza/canola e girassol e problemas de infra-estrutura (especialmente, quanto a armazenamento e transporte).

Souza (1990) e Roessing \& Guedes (1993) realizaram pesquisas sobre os diferentes fatores responsáveis pela expansão da cultura da soja no Brasil. O primeiro autor ressalta a importância da pesquisa agropecuária e o crescimento de setores 
industriais ligados à agricultura, especificamente à soja, como fatores explicativos adicionais para a expansão da cultura da soja no Brasil. Somam-se a esse contexto as políticas econômicas, globais e setoriais, que desempenharam um papel significativo para a modernização do setor. Roessing \& Guedes (1993) analisam a importância econômica do complexo soja e a expansão e crescimento da sojicultura na região dos cerrados. Para tanto, enfatizam as políticas econômicas adotadas como suporte para o desenvolvimento do setor. Além desses trabalhos há outros que analisam a expansão da soja em nível de estados, como, por exemplo, Igreja (1999) analisando as características da expansão da lavoura da soja no Paraná.

Existem vários trabalhos tendo a análise fatorial, pelo método dos componentes principais, como metodologia de estudo. No que se refere às principais contribuições empíricas sobre a modernização do setor agrícola brasileiro destacam-se: Llanillo (1984), Hoffmann \& Kageyama (1985), Hoffmann \& Kassouf (1989), Gomes (1990), Hoffmann (1992), Figueiredo (1996), Shikida (1997) e Meyer \& Braga (1998).

Destes trabalhos apenas dois se destinam a analisar os impactos causados pela expansão de uma determinada cultura: Shikida (1997) analisa os principais condicionantes da evolução diferenciada ocorrida na agroindústria canavieira do Brasil; e, Gomes (1990) tem como um de seus objetivos analisar o grau de modernização da Região Tradicional e da Região em Expansão da soja.

Um dos pontos a se destacar no trabalho de Shikida (1997) é a abordagem feita da modernização da agroindústria e não somente da agricultura, o que vem de encontro com a proposta de estudo do presente trabalho. Outros trabalhos já tinham ressaltado a relevância da abordagem conjunta da modernização dos segmentos agrícola e agroindustrial. Por exemplo, Kageyama \& Silveira (1997), que estudaram as desigualdades regionais do desenvolvimento agrícola do Brasil - utilizando Componentes Principais - ressaltam que uma das limitações de seu trabalho foi não ter utilizado variáveis relảionadas com a agroindústria, o que representou uma lacuna para a compreensão das desigualdades regionais. 
Gomes (1990) utilizou a análise fatorial para avaliar a expansão da cultura da soja em duas regiões do Brasil: Região Tradicional (Rio Grande do Sul, Santa Catarina, Paraná e São Paulo) e Região em Expansão (Região Centro-Oeste e Minas Gerais). O período analisado foi de 1970 a 1980.

O presente trabalho difere do trabalho de Gomes (1990) por considerar um período mais recente, por incluir a análise da agroindústria processadora e por trabalhar com três regiões: as duas acima citadas e mais a área de expansão no nordeste.

\subsection{Estrutura do trabalho}

O presente trabalho encontra-se estruturado em cinco capítulos, incluindo esta introdução. O segundo capítulo se compõe de duas partes. Na primeira, apresenta-se a evolução da produção da soja no Brasil, com ênfase no período de 1970 a 1999. A segunda parte apresenta, para o mesmo período, a evolução da indústria de processamento da soja no País. No capítulo três é exposta a metodologia que será utilizada para realizar os propósitos da presente pesquisa. No capítulo quatro há a interpretação dos resultados da análise fatorial, mostrando a evolução diferenciada da produção e do processamento da soja no Brasil, destacando-se as variáveis que mensuram a concentração e modernização dessas atividades. Finalmente, o capítulo cinco traz as conclusões do trabalho. 


\section{EVOLUÇÃO DA CULTURA E DO PROCESSAMENTO INDUSTRIAL DA SOJA NO BRASIL}

Neste capítulo analisa-se a evolução da lavoura da soja no Brasil e do seu processamento industrial. $\mathrm{O}$ item 2.1 procura evidenciar as diferentes fases da expansão da cultura da soja entre os estados brasileiros, ressaltando os aspectos que destacam a evolução diferenciada desta atividade entre as regiões. O item 2.2 destaca o papel da agroindústria processadora na evolução da lavoura da soja e analisa a evolução diferenciada desta agroindústria entre as regiões aqui consideradas.

\subsection{Evolução da cultura da soja}

A cultura da soja foi introduzida no Brasil, em 1908, por imigrantes japoneses, iniciando seu desenvolvimento na região sul do País, mais especificamente no Estado do Rio Grande do Sul. Sua utilização era, basicamente, como adubo verde ou forragem e in natura para a alimentação de suínos, servindo como complemento protéico ao milho, mandioca e abóbora.

A soja passou a ser cultivada comercialmente a partir de 1936 no Rio Grande do Sul, tornando-se uma importante cultura no Estado na década de 50 (Fredo \& Trevisan, 1974, apud Zockun, 1980).

No início, a expansão da cultura da soja no Rio Grande do Sul foi concentrada na zona do Alto Uruguai. destacando o município de Santa Rosa, localizado na região nordeste do estado. A partir dos anos 50, a zona das Missões, fronteira oeste deste estado, que tinha sua economia basicamente voltada para a pecuária extensiva, expandiu 
a cultura do trigo, atraindo a soja. Destaca-se também a zona do Planalto Médio, região central do estado, que apesar de apresentar solos mais pobres, reunia condições ideais para a mecanização (Zockun, 1980).

Outro estado que compõe a Região Tradicional de cultivo da soja é o Paraná. O ano de 1952 é indicado como sendo o primeiro ano de produção de soja nesse estado. Pode-se destacar duas regiões pioneiras no cultivo desta oleaginosa no Paraná: norte e sudoeste do estado. Na região norte, em 1954, foram semeadas 2000 sacas de sementes trazidas de São Paulo para servir de adubação verde para os cafezais. Juntamente aos interesses dos cafeicultores, uma firma exportadora de cereais vinha estimulando a produção de soja no Estado, através do fornecimento de sementes e se dispondo a financiar a cultura e realizar contratos de compra da produção. Diferentemente, na região sudoeste do Paraná a cultura da soja desenvolveu-se na década de 60 , como opção de rotação com a cultura do trigo, intensificando o uso de capital e terra. A partir destas duas regiões, a soja foi se expandindo para os Campos Gerais e para a região noroeste do Estado do Paraná (Zockun, 1980).

A Região Tradicional inclui, também, os Estados de São Paulo e Santa Catarina, mas nestes estados a cultura da soja não se expandiu de modo tão acentuado, como nos outros estados já comentados.

Mesmo apresentando essa expansão frente às demais culturas nos estados do Rio Grande do Sul e do Paraná, a cultura da soja foi inexpressiva até o fim da década de 60. A partir de então e, principalmente na década de 70, esta cultura tem apresentado grande expansão nos estados citados (ver Figura 1).

Segundo Roessing \& Santos (1997, p.37), "no Brasil, a partir do final dos anos 60, a produção de soja teve crescimento extraordinário, alterando sua importância relativa nos cenários nacional e internacional. Com exceção das safras 1977-78 e 197879, para as quais as condições climáticas foram extremamente adversas, a produção de 
soja aumentou rapidamente, entre 1970 e 1980, de um milhão e meio para 15 milhões de toneladas".

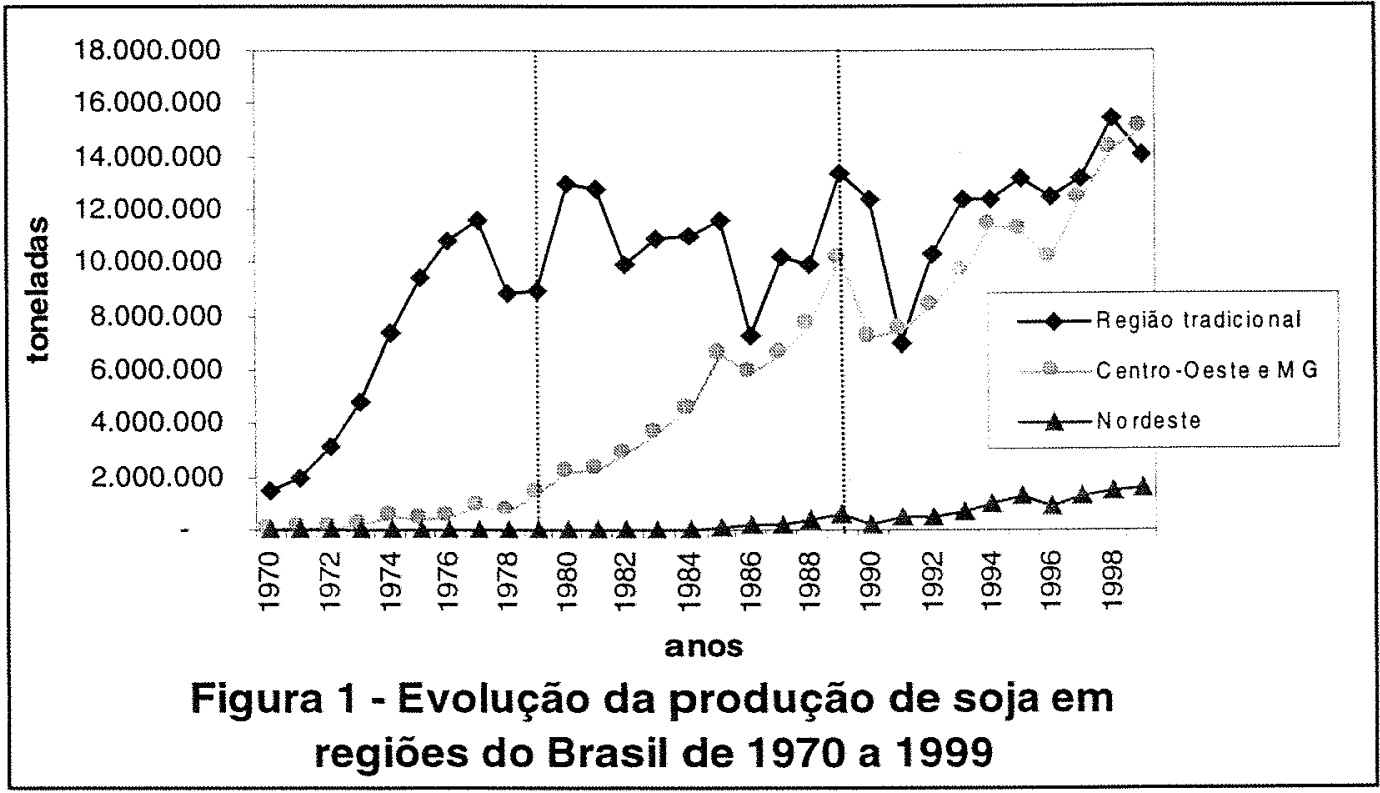

Fonte: 1970 a 1998: Anuário Estatístico do Brasil;

1999: Levantamento Sistemático da Produção Ágrícola.

Nota: valores da produção obtidos através dos anos-safra, ou seja, a semeadura da soja é realizada no ano anterior a sua colheita.

A década de 70 foi marcada por crescimento extraordinário da produção de soja, alterando a participação do Brasil no mercado internacional. Em 1980 a participação do Brasil no mercado mundial deste produto foi de $18,7 \%$, contra $3,6 \%$ em 1970 . Neste período de 11 anos o País passou à frente da China, colocando-se como segundo produtor mundial de soja.

Conforme Bertrand et al. (1987, p.94-95), "a expansão da soja resulta, pois, de uma série de interesses convergentes: os do Estado, no quadro do "milagre econômico"; os de certos produtores, em busca de alternativas de cultura; os industriais, que vêem um fator de dinamização da produção".

Como o objetivo do Governo era incentivar a produção nacional de bens exportáveis e com maior valor agregado, as culturas que podiam ser internamente processadas e tinham grande demanda externa foram beneficiadas pela política agrícola 
vigente na época. Havia um sistema de crédito com taxas de juros negativas apoiando as culturas de exportação, tradicionais ou não. A soja transformou-se, então, em uma das culturas essenciais neste cenário, onde a demanda mundial era crescente e o grão podia ser transformado industrialmente sob a forma de óleo e farelo (Bertrand et al., 1987).

Não obstante, a maior parte da expansão da produção de soja estava vinculada ao aumento de área cultivada, e não a aumentos de produtividade. Para o período de $1970 \mathrm{a}$ 1979, verificou-se uma taxa anual média de crescimento da produção nacional de 25,55\%. Calculando a mesma taxa para a expansão da área e da produtividade os resultados foram $23,47 \%$ e $1,68 \%$, respectivamente. Este significativo desempenho da produção foi resultado do crescimento da produção da soja na Região Tradicional de cultivo (região sul e Estado de São Paulo).

Conforme Williams \& Thompson (1988, p.13), "as melhorias ocorridas nos rendimentos refletem em boa medida o uso de variedades adaptadas às condições locais, melhoria nos tratos culturais, e um deslocamento para solos mais férteis, virgens. A variabilidade nos rendimentos entre estados decorre de diferenças básicas em fatores tais como solo e clima".

A expansão da cultura da soja para a região dos cerrados teve seu alicerce no desenvolvimento regional do Centro-Oeste do País, iniciado no começo da década de 70. Com o objetivo de gerar matérias-primas para as indústrias de regiões mais desenvolvidas do país, abastecer os centros-urbanos e aumentar a exportação de produtos não tradicionais, o Governo estabeleceu uma política que visava o aumento da produção e produtividade nas atividades agropecuárias.

Segundo Roessing \& Guedes (1993, p.29), "um reforço à integração da região dos cerrados e à criação de uma infra-estrutura para o desenvolvimento da agropecuária regional surgiu em 1971 com o Decreto de criação do Programa de Desenvolvimento do Centro-Oeste (PRODOESTE), integrado no $1^{\underline{0}}$ Plano Nacional de Desenvolvimento Econômico e Social (1972/74)". 
Os programas e projetos de desenvolvimento das atividades agropecuárias foram realizados por organismos federais e estaduais e apoiados com recursos oriundos de crédito rural, concedidos através do Sistema Nacional de Crédito Rural (SNCR). Estes programas foram integrados com a realização de pesquisa e experimentação agropecuária através de institutos sediados em Mato Grosso, Goiás, Minas Gerais e Distrito Federal (Roessing \& Guedes, 1993).

A criação do Programa de Desenvolvimento dos Cerrados (POLOCENTRO), em 1975, proporcionou um novo estímulo para o desenvolvimento dos cerrados. Este programa, que teve como principal instrumento de incentivo o crédito rural, objetivava "o desenvolvimento e a modernização das atividades agropecuárias da Região CentroOeste e do oeste do Estado de Minas Gerais, mediante a ocupação racional de áreas com características de cerrados e seu aproveitamento em escala empresarial" (Mueller, 1990, p.53).

Somam-se a este contexto, conforme Lazzarini \& Nunes (1998), três razões básicas de interesse pela região dos cerrados: aspectos edafo-climáticos favoráveis, busca de terras mais baratas e o interesse em explorar economias de escala. Assim, através da Figura 2, pode-se observar que a Região Centro-Oeste e Minas Gerais em 1980, já representava $14 \%$ da produção nacional de soja.

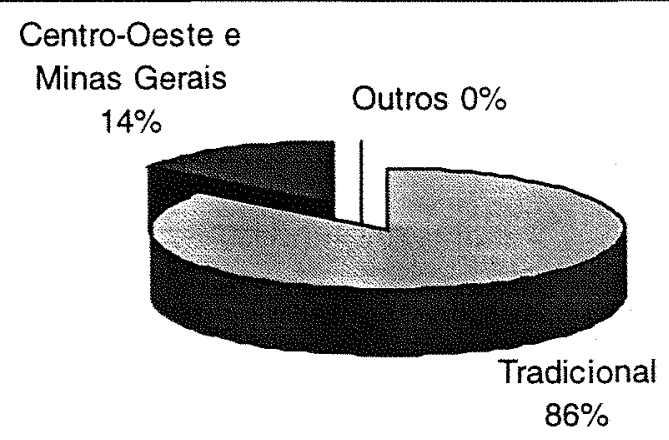

Figura 2 - Participação das regiões do Brasil na produção de soja em 1980

Fonte: Anuário Estatístico do Brasil. 
Mas é na década de 80 que a cultura da soja na Região Centro-Oeste e em Minas Gerais teve maior expansão, apresentando taxas médias de crescimento da produção de $18,63 \%$ ao ano. A área expandiu, no mesmo período, com taxa média anual de 15,55\%, e a produtividade, $2,65 \%$. Assim, esta região tornou-se fundamental para a produção nacional de soja (Figura 3) e para o desempenho do Brasil no comércio exterior desse produto.

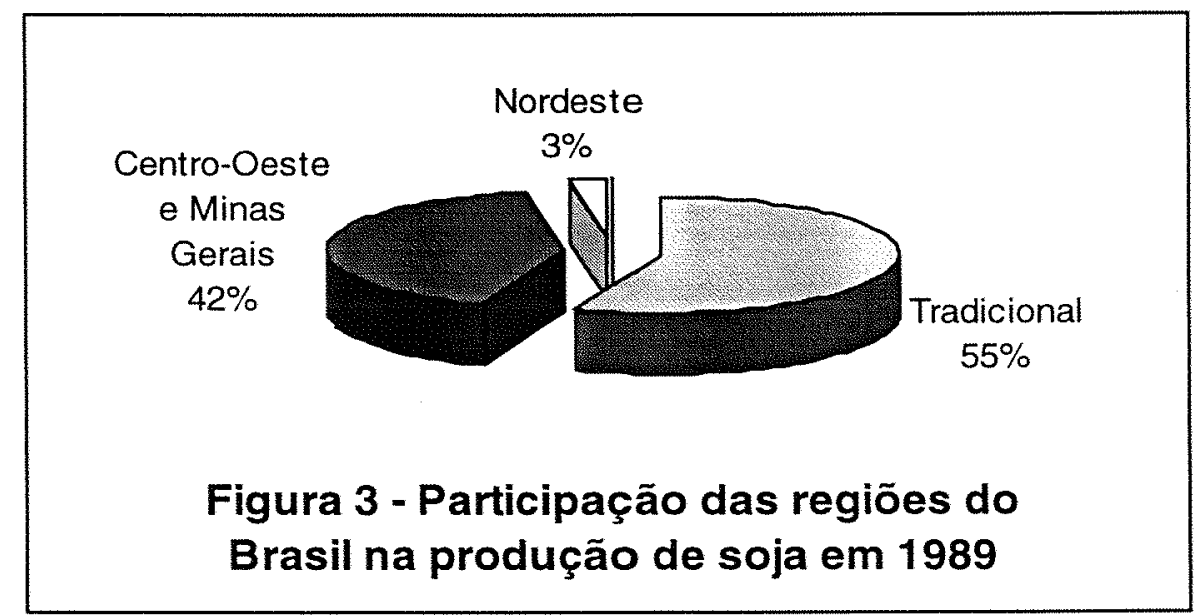

Fonte: Anuário Estatístico do Brasil.

A década de 90 iniciou com forte redução da produção de soja no Brasil, em decorrência, principalmente, de problemas climáticos na safra 1990/91, ou seja, a falta de chuva nos períodos da produção de soja (floração e enchimento de grãos) ${ }^{3}$. A partir de 1992 a produção voltou a crescer (Figura 1). As taxas geométricas de crescimento da área, produção, e produtividade no Brasil entre 1992 e 1999 foram, respectivamente, $3,95 \%, 6,17 \%$ e $2,13 \%$

A Região Nordeste tem apresentado grande expansão da cultura da soja, principalmente a partir dos anos 90, com destaque para o período de 1995 a 1999. Essa região no final da década de 80 representou $3 \%$ da produção brasileira de soja, com a Bahia contribuindo com $93,7 \%$ da produção regional. Cardoso (1997) analisou as alterações na composição da área agrícola no Estado da Bahia, no período de 1985 a 1994. Verificou que entre as principais culturas no estado, a soja for a que representou

\footnotetext{
${ }^{3}$ ROESSING, A.C. (Embrapa. Centro Nacional de Pesquisa de Soja, Londrina). Comunicação pessoal, 2000.
} 
maior crescimento nas áreas plantadas, incorporando 371 mil hectares. No sub-período de 1985/90 houve maior expansão da cultura, com efeito-escala e efeito-substituição positivos. O sub-período de 1990/94, a cultura da soja apresentou crescimento modesto em relação a segunda metade da década de 80 . A expansão da soja ocorreu através da substituição de outras culturas, pois seu efeito escala foi negativo. O Estado do Maranhão, apesar de ser bem menos representativo na produção de soja na região, vem obtendo crescimentos expressivos. Sua produção passou de 38,6 mil toneladas de soja em 1989 passou para 409 mil toneladas em 1999.

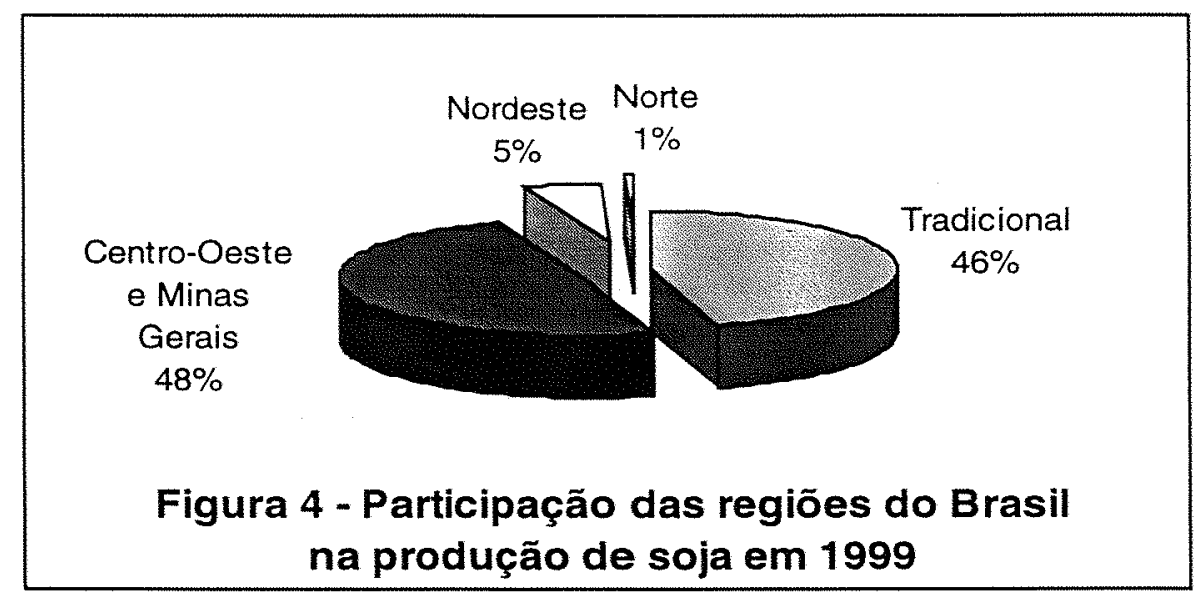

Fonte: Levantamento Sistemático da Produção Agrícola

Para Lazzarini \& Nunes (1998), a expansão da cultura da soja no território brasileiro pode considerar, atualmente, três importantes fronteiras agrícolas: Chapada dos Parecis em Mato Grosso, Balsas em Maranhão e Barreiras na Bahia. A Chapada dos Parecis apresenta potencial destacado devido ao desenvolvimento do corredor Noroeste ${ }^{4}$, com uso dos Rios Madeira e Amazonas. Balsas apresenta boas perspectivas de desenvolvimento da cultura da soja, em função da utilização do sistema ferroviário Norte-Sul/Carajás e do escoamento via complexo Portuário Ponta da Madeira/Itaqui. E a região de Barreiras tem possibilidade de crescimento em função de novas áreas e do futuro desenvolvimento da hidrovia do São Francisco.

\footnotetext{
${ }^{4}$ Conforme Paula \& Favaret Filho (1998, p.141), "o corredor multimodal de transporte do Noroeste abrange as áreas do norte do Mato Grosso, Rondônia e sul do Amazonas. envolvendo o transporte hidroviário nos rios Madeira e Amazonas da foz até Itacoatiara. e o transporte rodoviário entre Porto Velho e a Chapada dos Parecis".
} 
Assim, as regiões nordeste e parte do centro-oeste (especialmente o oeste do Mato Grosso) se constituem na mais nova fronteira de desenvolvimento da cultura da soja no Brasil.

\subsubsection{Alguns aspectos da comercialização da soja}

A comercialização da soja é realizada pelo setor privado, onde os principais agentes de comercialização são as cooperativas de produtores, as indústrias de processamento e os intermediários. Deve-se salientar que muitas dessas cooperativas atuam também no processamento da soja.

Quando ocorreu o aumento significativo na produção de soja no país (década de 70), a região sul já possuía uma estrutura de cooperativas em decorrência da cultura do trigo. Isso veio atender as necessidades dos produtores de soja, que em grande parte eram os mesmos produtores de trigo. Segundo Hoffmann et al. (1985), a consolidação da soja como a cultura de maior valor comercial no Rio Grande do Sul, no início da década de 70 , proporcionou a expansão das cooperativas, que passaram a concorrer entre si e com as indústrias no processamento da soja.

A participação das cooperativas na comercialização da soja na Região Tradicional é expressiva. No período de 1975 a 1995, mais de 50\% da produção da soja no Rio Grande do Sul e Paraná foram negociados através das cooperativas. O Estado de Santa Catarina apresentou um crescimento acentuado da importância das cooperativas neste mesmo período: em 1975 as cooperativas comercializaram cerca de $31 \%$ da produção de soja e em 1995 esse percentual correspondeu a quase 62\%. Em São Paulo a participação das cooperativas aumentou em 1995 em relação ao que se tinha na década de 80 (ver Tabela 1). Nota-se, porém, que a importância das cooperativas na comercialização da soja não é homogênea entre os estados da Região Tradicional. A concentração das cooperativas encontra-se nos estados do Rio Grande do Sul, Santa Catarina e Paraná e está relacionada com a estrutura produtiva que é caracterizada por pequenas e médias lavouras e com as características dos produtores, o que não acontece nas demais regiões analisadas. 
Na Região Centro-Oeste e Minas Gerais, as cooperativas não se constituem o principal agente na comercialização da soja. Deve-se destacar o Estado de Mato Grosso do Sul, que deteve a maior participação das cooperativas na comercialização, para o período analisado. Nos dois Estados que representam a Região Nordeste, os dados disponíveis correspondem somente ao ano de 1995 e mostram a maior importância das cooperativas no Maranhão quanto à comercialização de soja.

Tabela 1. Percentual da produção total da soja que foi entregue às cooperativas - estados das Regiões Tradicional, Centro-Oeste e Minas Gerais, e Nordeste - anos selecionados.

\begin{tabular}{cccccc}
\hline \multirow{2}{*}{ Regióes } & Estados & \multicolumn{4}{c}{ Cooperativas } \\
\cline { 3 - 6 } & & $\mathbf{1 9 7 5}$ & $\mathbf{1 9 8 0}$ & $\mathbf{1 9 8 5}$ & $\mathbf{1 9 9 5}$ \\
\hline Região & RS & 64,0 & 64,2 & 81,0 & 55,7 \\
Tradicional & SC & 30,6 & 35,9 & 41,7 & 61,5 \\
& PR & 45,2 & 60,3 & 70,1 & 66,2 \\
& SP & 24,5 & 23,8 & $4,0^{*}$ & 39,8 \\
\hline Região & MT & - & 3,7 & 17,4 & 5,2 \\
Centro-Oeste & MS & 30,2 & 27,7 & 32,4 & 13,4 \\
e Minas Gerais & GO & 5,9 & 5,0 & $29,8^{*}$ & 12,5 \\
& MG & 1,6 & 19,5 & 25,2 & 14,8 \\
\hline Região & BA & - & - & - & 5,3 \\
Nordeste & MA & - & - & - & 27,8 \\
\hline
\end{tabular}

Fonte: elaborada a partir dos Censos Agropecuários do RS, SC, PR, SP, MT, MS, GO, MG, BA e MA de 1975, 1980, 1985 e 1995.

* Apesar dos contraste desses valores em relação ao ano anterior, são os valores que constam no Censo Agropecuário.

A vinculação dos produtores às cooperativas tem permitido, em alguns casos, uma melhoria tecnológica. Um exemplo é o caso das cooperativas de Arapoti, Batavo e Castrolanda no Paraná (com sedes em Arapoti, Carambeí e Castro, respectivamente). Os cooperados dessas cooperativas sustentam a Fundação $\mathrm{ABC}$, a qual adapta tecnologia à região e a transfere aos agrônomos. Esses, por sua vez, orientam os sojicultores de acordo com um pacote tecnológico apropriado à região. Decorrente dessa situação, as lavouras dos agricultores da região mencionada possuem alta produtividade em termos do cenário nacional, e usando terras com menor aptidão agrícola.

Situação como a descrita anteriormente não ocorre em todas as regiões onde 
atuam as cooperativas. A situação citada é mais comum em regiões onde as cooperativas têm unidades processadoras de soja e/ou centralizam a comercialização da soja dos cooperados.

Outro canal de comercialização da soja é a venda direta à indústria processadora. Verifica-se que na Região Tradicional o Estado de São Paulo teve a maior parcela da soja produzida entregue diretamente à indústria (ver Tabela 2). Os demais estados desta região não apresentam um percentual alto neste canal de comercialização, mas cabe ressaltar o aumento da quantidade de soja produzida entregue à indústria nos estados do Rio Grande do Sul e Santa Catarina, entre 1975 e 1995.

Tabela 2. Percentual da produção total da soja que foi entregue às indústrias - estados das Regiões Tradicional, Centro-Oeste e Minas Gerais, e Nordeste - anos selecionados.

\begin{tabular}{ccrccc}
\hline Regióes & Estados & \multicolumn{4}{c}{ Indústrias processadoras } \\
\cline { 3 - 6 } & & $\mathbf{1 9 7 5}$ & $\mathbf{1 9 8 0}$ & $\mathbf{1 9 8 5}$ & $\mathbf{1 9 9 5}$ \\
\hline Região & RS & 7,2 & 12,4 & 5,7 & 19,8 \\
Tradicional & SC & 7,7 & 20,1 & 23,9 & 16,8 \\
& PR & 12,4 & 12,7 & 12,0 & 15,6 \\
& SP & 42,6 & 56,1 & 43,2 & 34,9 \\
\hline Região & MT & - & 58,5 & 33,4 & 40,2 \\
Centro-Oeste & MS & 14,6 & 31,2 & 25,3 & 34,7 \\
e Minas Gerais & GO & 25,3 & 60,8 & 38,4 & 50,9 \\
& MG & 39,3 & 53,7 & 49,9 & 47,1 \\
\hline Região & BA & - & - & - & 71,1 \\
Nordeste & MA & - & - & - & 28,6 \\
\hline
\end{tabular}

Fonte: elaborada a partir dos Censos Agropecuários do RS, SC, PR, SP, MT, MS, GO, MG, BA e MA de 1975, 1980, 1985 e 1995.

Esse quadro é oposto ao se analisar a Região Centro-Oeste e Minas Gerais, na qual a indústria tem grande participação na comercialização da soja. $\mathrm{Na}$ Região Nordeste, destaca-se o Estado Bahia com $71 \%$ da soja produzida entregue à indústria em 1995. Isso não significa dizer que a produção é totalmente processada nos estados onde a soja foi produzida. No caso da Região Centro-Oeste e Minas Gerais, que produziram 11,2 milhões de toneladas de soja em 1995, apenas 8,5 milhões de toneladas no máximo poderiam ser processadas na região. Assim, mesmo com o aumento do parque 
processador nessa região, ainda há grandes volumes de soja que são processados no Paraná e São Paulo.

O papel do intermediário no processo de comercialização da soja diminuiu acentuadamente nos estados de Santa Catarina e Paraná, entre 1975 e 1995 (Tabela 3). A grande presença desse agente pode ser verificada na região Centro--Oeste, especialmente em Mato Grosso e Mato Grosso do Sul, e em Minas Gerais. No Estado do Maranhão (Região Nordeste) esta é a principal forma de comercialização, correspondendo-lhe cerca de $40 \%$ da produção de soja no estado.

Tabela 3. Percentual da produção total da soja entregue aos intermediários - estados das Regiões Tradicional, Centro-Oeste e Minas Gerais, e Nordeste - anos selecionados.

\begin{tabular}{cccccc}
\hline \multirow{2}{*}{ Regiões } & Estados & \multicolumn{5}{c}{ Intermediários } \\
\cline { 2 - 6 } & & $\mathbf{1 9 7 5}$ & $\mathbf{1 9 8 0}$ & $\mathbf{1 9 8 5}$ & $\mathbf{1 9 9 5}$ \\
\hline Região & RS & 26,5 & 21,3 & 10,5 & 20,7 \\
Tradicional & SC & 57,2 & 39,6 & 33,1 & 18,7 \\
& PR & 41,0 & 25,8 & 17,0 & 15,6 \\
& SP & 32,0 & 18,8 & 50,8 & 20,7 \\
\hline Região & MT & - & 34,9 & 45,2 & 51,1 \\
Centro-Oeste & MS & 53,9 & 40,2 & 40,7 & 47,7 \\
e Minas Gerais & GO & 68,4 & 33,5 & 30,5 & 33,8 \\
& MG & 52,1 & 21,8 & 22,2 & 31,3 \\
\hline Região & BA & - & - & - & 17,8 \\
Nordeste & MA & - & - & - & 41,4 \\
\hline
\end{tabular}

Fonte: elaborada a partir dos Censos Agropecuários do RS, SC, PR, SP, MT, MS, GO, MG, BA e MA de 1975, 1980, 1985 e 1995.

\subsubsection{Tamanho da lavoura e uso de tecnologia na sojicultura}

Segundo Hoffmann et al. (1985), nos anos 70 houve aumento da concentração de terra e de capitais na agropecuária. Isto está coerente com o fato de que para haver o aumento da produtividade e a plena utilização dos meios de produção por uma lavoura totalmente mecanizada, exige-se o aumento do tamanho mínimo da propriedade. 
Os tamanhos das áreas cultivadas com soja no Brasil diferem entre as regiões. A Região Tradicional é caracterizada por áreas pequenas e médias ${ }^{5}$; mesmo apresentando reduções da participação da pequena lavoura de soja nos estados (exceto São Paulo) e aumento da grande lavoura, entre 1975 e 1995 (Tabela 4).

Tabela 4. Distribuição da área cultivada com soja na Região Tradicional em três estratos de área das lavouras de soja - anos selecionados (valores em percentuais).

\begin{tabular}{|c|c|c|c|c|c|c|c|c|c|c|c|c|c|c|c|c|}
\hline \multirow{2}{*}{$\begin{array}{l}\text { Tamanho da área } \\
\text { cultivada com soja }\end{array}$} & \multicolumn{4}{|c|}{ RS } & \multicolumn{4}{|c|}{$\mathrm{SC}$} & \multicolumn{4}{|c|}{ PR } & \multicolumn{4}{|c|}{$\mathbf{S P}$} \\
\hline & 1975 & 1980 & 1985 & 1995 & 1975 & 1980 & 1985 & 1995 & 1975 & 1980 & 1985 & 1995 & 1975 & 1980 & 1985 & 1995 \\
\hline Menos de 50 ha & 54,7 & 48,4 & 50,0 & 44.8 & 83,8 & 70,5 & 67,3 & 34,2 & 57,0 & 45,0 & 44,3 & 36,7 & 21,6 & 21,7 & 22,3 & 21,0 \\
\hline 50 a menos de 500 ha & 36,5 & 40,8 & 40,1 & 43.2 & 13,6 & 24.2 & 27,5 & 53.8 & 37,9 & 45.7 & 47,8 & 48,8 & 70,1 & 67,5 & 67,3 & 65,9 \\
\hline 500 ha e mais & 8,8 & 10,8 & 9,9 & 12.0 & 2.6 & 5,3 & 5.2 & 12.0 & 5,0 & 9.3 & 7,9 & 14,5 & 8,3 & 10,8 & 10,4 & 13,1 \\
\hline Total & 100 & 100 & 100 & 100 & 100 & 100 & 100 & 100 & 100 & 100 & 100 & 100 & 100 & 100 & 100 & 100 \\
\hline
\end{tabular}

Fonte: elaborada a partir dos Censos Agropecuários do RS, SC, PR, e SP de 1975, 1980, 1985 e 1995.

Na Região Centro-Oeste e Minas Gerais prevalecem as médias e grandes lavouras de soja. No período de 1975 a 1995 nota-se o aumento da participação da grande lavoura, principalmente de 1985 a 1995.

Tabela 5. Distribuição da área cultivada com soja na Região Centro-Oeste e Minas Gerais em três estratos de área das lavouras de soja - anos selecionados (valores em percentuais).

\begin{tabular}{|c|c|c|c|c|c|c|c|c|c|c|c|c|c|c|c|c|}
\hline \multirow{2}{*}{$\begin{array}{l}\text { Tamanho da área } \\
\text { cultivada com soja }\end{array}$} & \multicolumn{4}{|c|}{ MT } & \multicolumn{4}{|c|}{ MS } & \multicolumn{4}{|c|}{ GO } & \multicolumn{4}{|c|}{ MG } \\
\hline & 1975 & 1980 & 1985 & 1995 & 1975 & 1980 & 1985 & 1995 & 1975 & 1980 & 1985 & 1995 & 1975 & 1980 & 1985 & 1995 \\
\hline Menos de 50 ha & 0,0 & 2,2 & 2,1 & 0.3 & 28,4 & 8,1 & 6,1 & 4,9 & 15,2 & 7,6 & 4,9 & 3,1 & 12,3 & 7,1 & 6,1 & 4,0 \\
\hline 50 a menos de 500 ha & 0,0 & 46,2 & 35,5 & 18.4 & 51,3 & 41.2 & 42,5 & 43.1 & 66,7 & 62.6 & 53,0 & 43,6 & 64,2 & 66,0 & 64,0 & 55,6 \\
\hline 500 ha e mais & 0,0 & 51,6 & 62,4 & 81,3 & 20,3 & 50.7 & 51,4 & 52,0 & 18,1 & 29.8 & 42,1 & 53,3 & 23,5 & 26,9 & 29,9 & 40,4 \\
\hline Total & 100 & 100 & 100 & 100 & 100 & 100 & 100 & 100 & 100 & 100 & 100 & 100 & 100 & 100 & 100 & 100 \\
\hline
\end{tabular}

Fonte: elaborada a partir dos Censos Agropecuários do MT, MS, GO, e MG de 1975, 1980, 1985 e 1995.

5 Segundo o Censo Agropecuário, propriedade pequena pequena é a com menos de 50 hectares; propriedade média é de 50 a menos de 500 hectares; e a propriedade grande é a com 500 hectares ou mais. No trabalho considerou-se a mesma classificação para as lavouras. 
Na Região Nordeste a presença da grande lavoura de soja é mais acentuada, com a pequena lavoura não chegando a representar $1 \%$ do total.

Tabela 6. Distribuição da área cultivada com soja na Região Nordeste em três estratos de área das lavouras de soja, em 1995 (valores em percentuais).

\begin{tabular}{l|cc}
\hline \multirow{2}{*}{$\begin{array}{c}\text { Tamanho da área } \\
\text { cultivada com soja }\end{array}$} & BA & MA \\
\cline { 2 - 3 } & $\mathbf{1 9 9 5}$ & $\mathbf{1 9 9 5}$ \\
\hline Menos de 50 ha & 0,2 & 0,3 \\
50 a menos de 500 ha & 23,6 & 33,7 \\
500 ha e mais & 76,2 & 66,0 \\
\hline Total & 100,0 & 100,0 \\
\hline
\end{tabular}

Fonte: elaborada a partir dos Censos Agropecuários do BA e MA de 1995.

Assim, observa-se que os produtores da Região Centro-Oeste e Minas Gerais (destaque para Mato Grosso) e Região Nordeste possuem lavouras com áreas bem maiores que a Região Tradicional. Essa observação permite concluir que a expansão da soja nas duas primeiras regiões citadas aconteceu e está acontecendo em grandes extensões de terra, o que deve estar associado à busca de economia de escala. No entanto, a Região Tradicional, que não possui a mesma característica na estrutura produtiva, vem apresentado aumento do tamanho médio da lavoura de soja, pois a produção de soja torna-se menos rentável em pequenas lavouras.

No que se refere a modernização tecnológica da agricultura brasileira, verifica-se que na década de 70 esse processo se estabeleceu, em parte, através da utilização da quimificação (especialmente o uso de fertilizantes e defensivos químicos) e da mecanização (Kageyama \& Silva, 1983). Conforme esses autores, o consumo aparente de defensivos agrícolas, para o período de 1970/80, cresceu a uma taxa geométrica média de $7,2 \%$ ao ano e o consumo dos fertilizantes a $15,5 \%$ ao ano.

A utilização de insumos se constitui em importante inovação tecnológica, indicando que as lavouras estarão menos suscetíveis aos fatores naturais para conseguir melhor produtividade agrícola. $\mathrm{Na}$ Tabela 7 , observa-se a proporção da área de lavoura de soja que faz uso de adubação e defensivos na Região Tradicional. O Estado de Santa Catarina foi o que apresentou maior crescimento relativo na utilização desses insumos, 
entre 1975 e 1995.

Tabela 7. Proporção da área colhida de soja que utilizou adubação e defensivos em relação a área total cultivada com soja em cada estado da Região Tradicional - anos selecionados (valores em percentuais).

\begin{tabular}{|c|c|c|c|c|c|c|c|c|c|c|c|c|c|c|c|c|}
\hline \multirow{2}{*}{$\begin{array}{c}\text { Tecnologia } \\
\text { utilizada }\end{array}$} & \multicolumn{4}{|c|}{$\mathbf{R S}$} & \multicolumn{4}{|c|}{ SC } & \multicolumn{4}{|c|}{ PR } & \multicolumn{4}{|c|}{ SP } \\
\hline & 1975 & 1980 & 1985 & 1995 & 1975 & 1980 & 1985 & 1995 & 1975 & 1980 & 1985 & 1995 & 1975 & 1980 & 1985 & 1995 \\
\hline Adubaçäo & 72,8 & 86,7 & 84,1 & 92,0 & 34,3 & 57,1 & 61,0 & 95,7 & 72.7 & 93,5 & 94,8 & 97,3 & 98,6 & 99,4 & 98,9 & 99,4 \\
\hline Defensivo & 72,7 & 70,0 & 74,5 & 86,0 & 24,7 & 40,5 & 46,8 & 91,4 & 78,2 & 92,1 & 92,9 & 72,2 & 95,9 & 96,9 & 94,4 & 96,2 \\
\hline
\end{tabular}

Fonte: elaborada a partir dos Censos Agropecuários do RS, SC, PR, e SP de 1975, 1980, 1985 e 1995.

$\mathrm{Na}$ Região Centro-Oeste e Minas Gerais, desde a década de 70, o uso de defensivos e fertilizantes é generalizado e com maior frequiência nas lavouras de soja do que o observado na região sul do país.

Tabela 8. Proporção da área colhida de soja que utilizou adubação e defensivos em relação a área total cultivada com soja em cada estado da Região CentroOeste e Minas Gerais - anos selecionados (valores em percentuais).

\begin{tabular}{|c|c|c|c|c|c|c|c|c|c|c|c|c|c|c|c|c|}
\hline \multirow{2}{*}{$\begin{array}{l}\text { Tecnologia } \\
\text { utilizada }\end{array}$} & \multicolumn{4}{|c|}{ MT } & \multicolumn{4}{|c|}{ MS } & \multicolumn{4}{|c|}{ GO } & \multicolumn{4}{|c|}{ MG } \\
\hline & 1975 & 1980 & 1985 & 1995 & 1975 & 1980 & 1985 & 1995 & 1975 & 1980 & 1985 & 1995 & 1975 & 1980 & 1985 & 1995 \\
\hline Adubação & 0,0 & 99,0 & 98,6 & 98,6 & 75,7 & 96,4 & 96,0 & 97,7 & 98.3 & 99,8 & 99,4 & 99,7 & 96,5 & 99,3 & 98,7 & 97,9 \\
\hline Defensivo & 0,0 & 83,0 & 92,2 & 95,9 & 88,2 & 97,1 & 94,4 & 96.9 & 83,3 & 94,3 & 95,8 & 97,2 & 86,6 & 94,8 & 93,4 & 92,3 \\
\hline
\end{tabular}

Fonte: elaborada a partir dos Censos Agropecuários do MT, MS, GO, e MG de 1975, 1980, 1985 e 1995.

Os dados de 1995 para os estados da Bahia e Maranhão também demonstram o elevado e generalizado uso desses insumos entre as lavouras, com maior utilização na Bahia do que no Maranhão. 
Tabela 9. Proporção da área colhida de soja que utilizou adubação e defensivos em relação a área total cultivada com soja na Bahia e Maranhão em 1995 (valores em percentuais).

\begin{tabular}{c|cc}
\hline Tecnologia & BA & MA \\
\cline { 2 - 3 } utilizada & $\mathbf{1 9 9 5}$ & $\mathbf{1 9 9 5}$ \\
\hline Adubação & 98,4 & 88,5 \\
Defensivo & 98,7 & 85,7 \\
\hline
\end{tabular}

Fonte: elaborada a partir dos Censos Agropecuários do BA e MA de 1995

Quando se iniciou no Brasil as pesquisas técnico-científicas com soja, as pesquisas em nível mundial nas áreas biológica, mecânica e físico-química já se encontravam avançadas. Assim, foram transferidas para as lavouras brasileiras informações e produtos tecnológicos sofisticados, comparáveis àqueles que estavam sendo empregados nos principais países produtores. Dessa forma, o início da produção de soja no Brasil se dá com a importação de variedades dos Estados Unidos, próprias para serem cultivadas em latitudes de 30 a 35 graus (Souza, 1990).

Através de pesquisas nacionais foram desenvolvidas cultivares cada vez menos dependentes da latitude, permitindo a expansão da soja por várias regiões do Brasil. Segundo Souza (1990), a partir de 1980 foram desenvolvidas cultivares de período juvenil longo, que tornaram possível o cultivo em áreas tropicais de baixa latitude.

A utilização de adubos, defensivos e sementes melhoradas explicam, em parte, o crescimento na produtividade das lavouras de soja. O crescimento da produtividade da soja apresenta tendência positiva, apesar de possuir dimensão e ritmo de crescimento diferente nos estados (Figuras 5, 6 e 7). Por exemplo, entre 1992 e 1999, a produtividade da lavoura da soja cresceu à taxa anual de 1,38\% na Região Tradicional, 2,77\% na Região Centro-Oeste e Minas Gerais e 5,05\% na Região Nordeste. Isto se explica, também, pelas diferenças edafo-climáticas das regiões. 


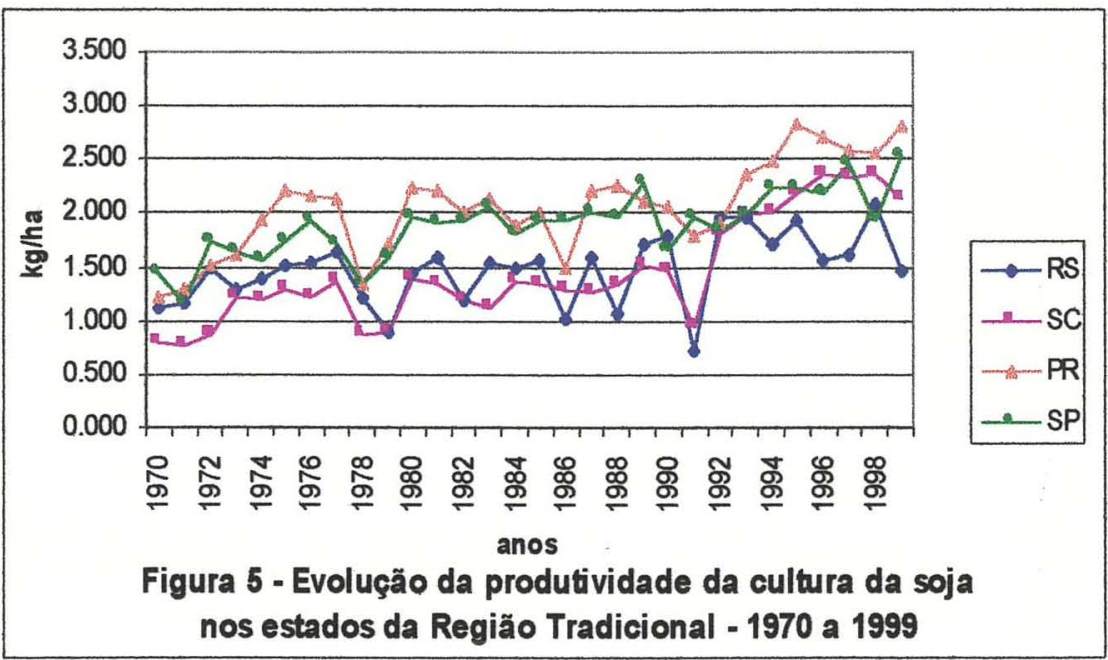

Fonte: 1969/70 a 1997/98: Anuário Estatístico do Brasil; 1998/99: Levantamento Sistemático da Produção Agrícola.

Nota: valores da produção obtidos através dos anos-safra, ou seja, a semeadura da soja é realizada no ano anterior a sua colheita.

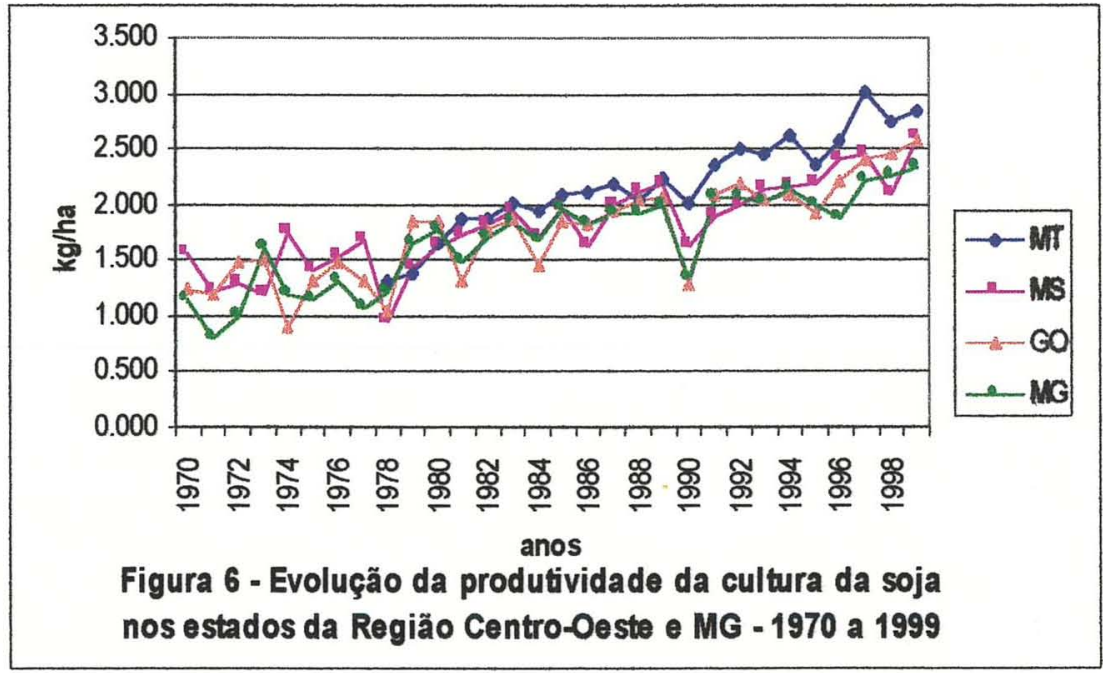

Fonte: 1969/70 a 1997/98: Anuário Estatístico do Brasil; 1998/99: Levantamento Sistemático da Produção Agrícola.

Nota: valores da produção obtidos através dos anos-safra, ou seja, a semeadura da soja é realizada no ano anterior a sua colheita. 


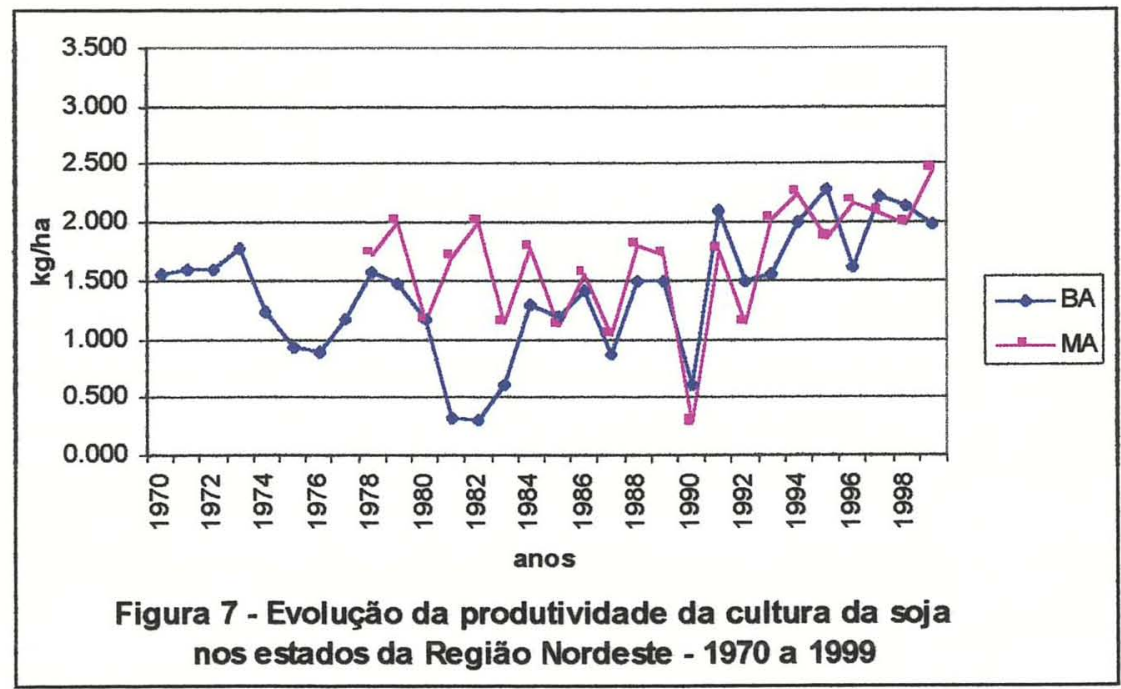

Fonte: 1969/70 a 1997/98: Anuário Estatístico do Brasil; 1998/99: Levantamento Sistemático da Produção Agrícola.

Nota: valores da produção obtidos através dos anos-safra, ou seja, a semeadura da soja é realizada no ano anterior a sua colheita.

\subsection{A agroindústria processadora}

Inicialmente, avalia-se o papel genérico da agroindústria processadora na evolução das lavouras e, na seqüência, trata-se do caso específico da soja (item 2.2.1). Em seguida, analisa-se a evolução da agroindústria processadora da soja, destacando as diferenças entre as regiões analisadas.

\subsubsection{O papel da agroindústria processadora de soja no desenvolvimento tecnológico desta cultura}

As agroindústrias processadoras (de soja e de outros produtos) encontram-se inseridas no processo de industrialização brasileira, tendo participações significativas na produção industrial. Mas é na década de 70 , a partir de uma política de financiamento para o setor, que houve o estímulo ao seu crescimento juntamente com a sua modernização, concentração e centralização do capital (Kageyama et al., 1987).

A presença do Estado como agente financeiro e regulador, estimulando as agroindústrias processadoras, é de enorme relevância para este processo. Para o financiamento do capital de giro das empresas o principal instrumento foi a Política de 
Garantia de Preços Mínimos do Governo (PGPM) através de mecanismos de Aquisição do Governo Federal (AGF) e Empréstimo do Governo Federal (EGF). O procedimento se viabilizava da seguinte maneira: a indústria processadora requeria um EGF junto a rede bancária para compor seus estoques. A taxa de juros era a mesma vigente no crédito rural. Esses recursos permitiam à indústria comprar matéria-prima do produtor pagando, ao menos, o preço mínimo. Após a comercialização do produto processado, havia a liquidação do empréstimo na rede bancária ${ }^{6}$.

Belik (1994, p.6-7) afirma que "houve um conjunto articulado de instrumentos de apoio ao segmento processador de produtos agropecuários que configuraram, na prática, uma política agroindustrial". O início dessa política agroindustrial se deu no final dos anos 60. A partir de 1967 foi instituída a conta FUNAGRI (Fundo Geral para Agricultura e Indústria), da qual as principais linhas de crédito derivavam-se, e que se transformou na principal conta gerida pelo Banco Central.

Ainda segundo Belik (1994), com a vinculação da conta FUNAGRI ao SNCR (Sistema Nacional de Crédito Rural) houve o início de um movimento de fragmentação voltado para o atendimento de demandas específicas de setores organizados. Os produtores tinham por objetivo obter linhas especiais de financiamentos para incentivar a industrialização de matérias-primas e a comercialização de insumos e equipamentos. Assim foram criados vários fundos buscando atender demandas de setores organizados. Entre eles destacam-se: a) Fundo Nacional de Refinanciamento Industrial (FNRI), agregando os programas PRODAGRI (Programa de Desenvolvimento Industrial), PAGRI (Programa Agroindústria), COREX/PAGRI (Programa de Corredores de Exportação Agroindustrial) e outros; b)PROÁLCOOL (Programa Nacional do ÁlcoolRural e Industrial); c) PGPM (Programa de Garantia de Preços Mínimos); d) PRONAGRI (Programa Nacional de Assistência à Agroindústria); e) FUNDECE (Fundo de Democratização do Capital das Empresas); f) PRONAZÉM (Programa Nacional de Armazenagem Nacional); e g) PROBOR (Programa de Incentivo à Produção de

\footnotetext{
${ }^{6}$ Teoricamente este mecanismo ainda pode ocorrer atualmente. A redução do volume de crédito rural, porém, não permite seu uso generalizado.
} 
Borracha Natural). As aplicações destinadas aos subfundos tiveram maior participação no FUNAGRI a partir de 1977, atingindo maior quantidade de recursos nos anos de 1981 e 1982 e declinando a partir desses anos.

Até o ano de 1986 os recursos destinados à agroindústria não eram discriminado por setores, mas eram apenas classificados como agroindústria (Paula, 2000) ${ }^{7}$. Dessa maneira, torna-se difícil, ou até mesmo impossível fazer uma análise dos recursos voltados para o fínanciamento da agroindústria da soja até o ano de 1986 - principal período de recursos governamentais destinados ao financiamento da agroindústria processadora da soja. Para a década de 90, pode-se verificar o volume de recursos destinados ao processamento da soja através da Tabela 10.

Tabela 10. Desembolsos do BNDES para o processamento de soja - 1990 a 1997 (em US\$ mil)

\begin{tabular}{|c|c|c|c|c|c|c|c|c|}
\hline & 1990 & 1991 & 1992 & 1993 & 1994 & 1995 & 1996 & 1997 \\
\hline $\begin{array}{l}\text { Refino de óleo } \\
\text { vegetal }\end{array}$ & 32.355 & 8.612 & 16.593 & 3.188 & 21.272 & 41.870 & 9.557 & 2.175 \\
\hline $\begin{array}{l}\text { Produção de óleo } \\
\text { vegetal }\end{array}$ & 246 & 257 & - & 22 & 446 & 2.551 & 2.248 & 4.414 \\
\hline $\begin{array}{l}\text { Preparo de } \\
\text { margarinas, } \\
\text { gorduras e óleos }\end{array}$ & - & - & - & 264 & - & 586 & 768 & 797 \\
\hline $\begin{array}{l}\text { Total da } \\
\text { agroindústria da } \\
\text { soja (A) }\end{array}$ & 32.338 & 8.869 & 16.593 & 3.474 & 21.718 & 45.007 & 12.573 & 7.386 \\
\hline $\begin{array}{l}\text { Total para todas as } \\
\text { agroindústrias (B) }\end{array}$ & 345.338 & 492.286 & 769.757 & 880.048 & 1.616 .862 & 1.887 .110 & 1.583 .690 & 2.530 .925 \\
\hline $\begin{array}{l}\text { Relação } \mathrm{A} / \mathrm{B} \mathrm{em} \\
\text { percentual }\end{array}$ & 9,4 & 1,8 & 2,2 & 0,4 & 1,3 & 1,3 & 0,8 & 0,3 \\
\hline
\end{tabular}

Fonte: Paula \& Favaret Filho, 1998, p.145

Nota: Agroindústria = agropecuária, indústria de alimentos e bebidas e indústria do fumo.

Juntamente com o crédito destinado ao setor, o governo utilizou outros mecanismos para incentivar o desenvolvimento do parque agroindustrial processador. Houve a intervenção reguladora do Governo através de cotas de exportação, confisco cambial, tabelamento de preços para o processamento industrial de produtos agropecuários, assegurando, dessa maneira, o abastecimento interno das indústrias.

Durante a segunda metade da década de 70 , período em que aconteceu a grande

\footnotetext{
${ }^{7}$ PAULA, S. (BNDES - Banco Nacional de Desenvolvimento Econômico e Social, Rio de Janeiro). Comunicação pessoal, 2000.
} 
expansão e consolidação das indústrias de processamento de soja, a relação entre os preços do grão, farelo e óleo no mercado internacional favorecia a exportação do produto in natura. Esta situação proporcionou conflitos entre os produtores, cooperativas, indústrias e exportadores. Para assegurar o abastecimento das indústrias processadoras o Governo interviu, reduzindo os custos do processamento - por meio de crédito subsidiado e das deduções fiscais (ICMS e IPI sobre os produtos exportados) principalmente, por tabelamento de preços e cotas de fornecimento e/ou exportação de soja (Kageyama et al., 1987).

A modernização das agroindústrias processadoras (de soja e outros produtos), que decorre do processo de concentração e centralização do capital nos anos 60 e 70, proporcionou uma nova articulação indústria-agricultura em substituição à articulação existente agricultura-indústria. São capitais industriais, muito deles internacionais, que apoiados numa política governamental procuraram se integrar à agricultura e até a outros setores com o objetivo de se valorizar. Dessa forma, as agroindústrias passam a fazer novas exigências da agricultura, como: tipo de produto, especificações sanitárias, prazos de entrega, etc., modificando a forma de produzir (Kageyama et al., 1987).

A presença da indústria processadora, reivindicando e proporcionando transformações tecnológicas no processo produtivo, é evidenciada nas cadeias produtivas do tomate, da avicultura e da laranja. No entanto, na cadeia produtiva do leite, da carne bovina e do café não pode ser verificado o mesmo (Farina \& Zylbersztajn, 1991).

Dada a importância da indústria processadora da soja e de todo o incentivo governamental concedido para seu desenvolvimento no país, coloca-se a necessidade de averiguar a existência dessa interdependência tecnológica indústria-agricultura no caso específico da soja.

O papel da agroindústria processadora de soja, atuando no processo produtivo, pode ser observado sob dois aspectos dentre os trabalhos consultados: um deles é a importância de um produto de maior qualidade, podendo dessa forma interferir na 
adoção de tecnologias por parte do produtor; o outro aspecto são as novas demandas sobre empresas de pesquisas agropecuárias.

Martins (1995) constata que, mesmo com toda a tecnologia agrícola utilizada na cultura da soja, existem questões relacionadas com a qualidade do produto que cabem ser ressaltadas, por exemplo: essa tecnologia tinha entre seus objetivos garantir uma matéria-prima de melhor qualidade para a indústria? Até que ponto essa tecnologia desenvolvida foi repassada e absorvida pelos diferentes tipos de produtores?

Segundo estudo de Borrás et al. (1996), a qualidade da soja é um importante fator para a indústria processadora, pois a má qualidade da matéria-prima além de representar elevação no custo de beneficiamento, provoca alterações na qualidade de seus derivados (óleo e farelo).

Souza (1990) e Rizzi \& Paula (1996) ressaltam que as empresas de processamento, ao exigirem um padrão de qualidade superior da soja, acabam impondo aos produtores a adoção de certas tecnologia, influenciando, dessa forma, o processo de modernização.

As indústrias aplicam descontos sobre o produtor quando os grãos são de baixa qualidade. Na avaliação e qualificação dos grãos, as indústrias de processamento consideram: umidade, grãos quebrados, impurezas e matérias-estranhas, umidade, grãos esverdeados e grãos avariados (grãos brotados, danificados, imaturos, chocos, e mofados). Conforme Martins (1995) os limites máximos acima dos quais as indústrias podem aplicar descontos são definidos pela Portaria 262 do MAARA de 23/11/93, a qual estipula limite livres de descontos (ver Tabela 11). Ultrapassando esses valores estipulados, as tabelas de desconto variam conforme a indústria. Conforme Martins (1995), as indústrias podem estabelecer, contratualmente, limites máximos referentes aos padrões de qualidade estipulados, podendo recusar o lote caso a soja não esteja dentro dos padrões exigidos. Mas, por outro lado, não existem estímulos para o produtor entregar a soja em condições ideais de industrialização (soja seca e limpa). 
Tabela 11. Percentual de limites livres de descontos ao produtor segundo fator de qualidade

\begin{tabular}{l|c}
\hline \multicolumn{1}{c|}{ Fator de Qualidade } & Padrão Básico \\
\hline Umidade & $14 \%$ \\
Grãos quebrados & $30 \%$ \\
Impurezas e matérias estranhas & $1 \%$ \\
Grãos avariados & $8 \%$ \\
Grãos esverdeados & $10 \%$ \\
\hline
\end{tabular}

Fonte: Martins, p.7, 1995.

Um dos problemas atualmente enfrentados pela indústria de processamento, evidenciado por Roessing \& Santos (1997) e Shroeder (1999), é o aumento da produtividade $(\mathrm{kg} / \mathrm{ha})$ juntamente com a redução do teor de proteína do grão de soja, ocasionado por algumas variedades. A relação inversa entre produtividade e a quantidade de proteína na soja coloca de um lado os produtores buscando maior rentabilidade na lavoura e de outro as indústrias processadoras buscando um produto que apresente alto teor protéico.

Conforme esse autores, as indústrias processadoras têm pouco controle sobre o conteúdo protéico e oleaginoso da soja que compram, dada a grande quantidade de soja recebida de várias regiões durante a safra. Uma solução viável, num primeiro momento, é o desenvolvimento de variedades que obtenham bons níveis de produtividade sem reduzir a proteína do grão.

\subsubsection{A evolução da indústria processadora da soja}

O segmento de industrialização da soja é caracterizado por empresas que se diferenciam pela capacidade instalada de esmagamento e pela origem de seu capital, podendo ser nacionais ou estrangeiras. Essas empresas (nacionais e estrangeiras) dividem-se em esmagadoras, integradas e comercializadoras. 
Conforme Castro (1993), as empresas esmagadoras restringem suas atividades ao processamento do grão de soja, gerando farelo e óleo bruto. As empresas integradas estão inseridas em vários mercados: óleos e derivados, rações, carnes e subprodutos. E as empresas comercializadoras, como o próprio nome diz, apenas comercializam o óleo bruto, comprando e vendendo o produto nos mercados internacionais.

O processamento industrial da soja no Brasil teve início na década de 50, sendo realizado por empresas nacionais de pequeno porte. A primeira unidade industrial foi a Incobrasa, localizada no Rio Grande do Sul. Em 1955, a Igol iniciou o processamento da soja, seguida pela Sanrig, em 1958. Com interesse no aumento da produção, as empresas processadoras incentivaram o cultivo distribuindo sementes. Mas com o aumento da produção de soja, empresas multinacionais instalaram-se na década de 70, como: Sanbra, Cargill e Unilever (Óleos \& Grãos, 1991).

Rizzi \& Paula (1996) afirmaram que estas empresas estrangeiras tinham como objetivo maior destinar os produtos processados (derivados da soja) ao mercado externo. As plantas industriais estavam localizadas no sul do país, em decorrência da disponibilidade do grão, passando a exercer influência na produção, comercialização e industrialização da soja.

Na década de 80, as empresas multinacionais processadoras de soja detinham alta participação no mercado interno de óleos vegetais. Visando este mercado potencial, outras empresas nacionais processadoras de soja surgem nesta década, podendo citar: Ceval, Sadia, Perdigão, dentre outras (Óleos \& Grãos, 1991).

Resultado do exposto anteriormente, houve acréscimo significativo na capacidade de esmagamento de soja no Brasil considerando o final dos anos 70 e o início da década de 80. Através da Tabela 12, verifica-se que, entre 1977 e 1982, a capacidade instalada apresentou acréscimo de $116,5 \%$. O restante da década de 80 apresentou um comportamento bem distinto, com pequeno acréscimo da capacidade instalada de esmagamento de oleaginosas. Outro ponto a ser ressaltado é que o aumento da capacidade de processamento no final da década de 70 realizou-se, em grande parte, 
através do aumento de plantas industriais de maior porte, ou seja, empresas com capacidade acima de $1.499 \mathrm{t} /$ dia. No período de 1982 a 1989, as plantas de médio porte aumentaram sua participação, com redução do número das plantas dos outros estratos. A década de 90 é marcada pelo aumento das plantas de maior porte. Cumpre ressaltar, a partir dos valores apresentados na Tabela 12, a contínua redução do número e da capacidade relativa das plantas de menor porte.

Tabela 12. Percentual da capacidade de esmagamento de oleaginosas no Brasil de acordo com o tamanho da planta (somente plantas ativas) - anos selecionados

\begin{tabular}{lccccccc}
\hline $\begin{array}{c}\text { Capacidade } \\
\text { (t/dia) }\end{array}$ & $\mathbf{1 9 7 7}$ & $\mathbf{1 9 8 2}$ & $\mathbf{1 9 8 5}$ & $\mathbf{1 9 8 9}$ & $\mathbf{1 9 9 3}$ & $\mathbf{1 9 9 5}$ & $\mathbf{1 9 9 7}$ \\
\hline Até 599 & & & & & & & \\
De 600 para 1.499 & $31,6 \%$ & $27,9 \%$ & $28,8 \%$ & $37,9 \%$ & $39,8 \%$ & $39,7 \%$ & $36,3 \%$ \\
Acima de 1.499 & $22,4 \%$ & $48,1 \%$ & $47,4 \%$ & $41,8 \%$ & $48,0 \%$ & $48,8 \%$ & $54,8 \%$ \\
Total (t/dia) & 41.567 & 89.989 & 91.329 & 100.426 & 95.250 & 116.280 & 104.195 \\
\hline
\end{tabular}

Fonte: ABIOVE, 1997.

Atualmente, as empresas multinacionais lideram a participação na capacidade de processamento da soja no mercado brasileiro. A Ceval, que até 1997 se constituía na maior processadora de soja do país, com capacidade de esmagamento total de 15.980 t/dia, foi adquirida pela Santista Alimentos, do Grupo Bunge.

Através da Tabela 13, pode-se verificar a evolução da capacidade instalada de processamento de oleaginosas nos estados do Brasil. Observa-se que no ano de 1977 o parque processador da soja concentrava-se na Região Tradicional do cultivo dessa oleaginosa. Em 1985, essa mesma região continuou sendo responsável por quase toda a soja processada no Brasil, representando $97,5 \%$ do total da capacidade instalada, apesar de a Região Centro-Oeste e Minas Gerais já deter 35,8\% da produção nacional de soja naquele ano.

À medida que, na década de 80 , continuou a ocorrer a expansão da produção de soja na Região Centro-Oeste e Minas Gerais, houve o aumento da capacidade instalada 
de processamento dessa oleaginosa na região. Em 1985, essa região detinha 2,5\% da capacidade instalada de processamento, aumentando sua participação para $14,1 \%$ em 1989. Em 1995 esse percentual já correspondia a 24,6\% e em 1998 a 26,3\% (destaque para os Estados de Mato Grosso e Goiás). Observa-se que a importância da região em questão no processamento industrial da soja é bem menor do que sua importância na lavoura deste produto. Isto implica no fato dessa região ser exportadora (para o mercado interno e externo) de soja em grão.

Tabela 13. Capacidade de esmagamento de oleaginosas para a Região Tradicional, a Região Centro-Oeste e Minas Gerais, e a Região Nordeste - anos selecionados.

\begin{tabular}{|c|c|c|c|c|c|c|c|c|c|c|c|}
\hline \multirow[t]{2}{*}{ Regiões } & \multirow[t]{2}{*}{ Estado } & \multicolumn{2}{|c|}{1977} & \multicolumn{2}{|c|}{1985} & \multicolumn{2}{|c|}{1989} & \multicolumn{2}{|c|}{1995} & \multicolumn{2}{|c|}{1998} \\
\hline & & T/dia & $\%$ & $t /$ dia & $\%$ & t/dia & $\%$ & $t / d i a$ & $\%$ & t/dia & $\%$ \\
\hline Região & RS & 15.642 & 38,6 & 34.449 & 36,0 & 26.238 & 25,6 & 29.000 & 24,9 & 28.930 & 23,9 \\
\hline \multirow[t]{3}{*}{ Tradicional } & SC & 2120 & 5,2 & 8.220 & 8,6 & 6.020 & 5,9 & 5.075 & 4,4 & 5.210 & 4,3 \\
\hline & PR & 12.092 & 29,8 & 34.200 & 35,8 & 33.940 & 33,2 & 35.370 & 30,4 & 36.770 & 30,4 \\
\hline & SP & 10.095 & 24,9 & 16.330 & $I 7, I$ & 19.403 & 19,0 & 13.565 & 11,7 & 13.780 & 11,4 \\
\hline Região & MT & 0 & - & 0 & - & 1.200 & 1,2 & 8.330 & 7,2 & 8.770 & 7,2 \\
\hline Centro- & MS & 0 & - & 950 & 1,0 & 3.800 & 3,7 & 6.980 & 6,0 & 7.480 & 6,2 \\
\hline Oeste e & GO & 0 & - & 800 & 0,8 & 5.300 & 5,2 & 9.000 & 7,7 & 9.660 & 8,0 \\
\hline MG & MG & 585 & 1,5 & 690 & 0.7 & 4.100 & 4,0 & 4.300 & 3,7 & 5.900 & 4,9 \\
\hline Região & $\mathrm{BA}$ & 0 & - & - & - & 1.550 & 1,5 & 2.500 & 2,2 & 2.750 & 2,3 \\
\hline Nordeste & MA & 0 & - & - & - & - & - & - & - & - & - \\
\hline \multirow[t]{2}{*}{ Outros* } & & - & - & - & - & 700 & 0,7 & 2.060 & 1,8 & 1.660 & 1,4 \\
\hline & Total & 40.534 & 100,0 & 95.639 & 100,0 & 102.251 & 100,0 & 116.280 & 100,0 & 120.910 & 100,0 \\
\hline
\end{tabular}

Fonte: ano de 1977: Williams \& Thompson (1988); anos de 1985 e 1989: Rizzi \& Paula (1996); ano de 1995: Lazzarini \& Nunes (1997); e ano de 1998: ABIOVE (2000).

A indústria processadora de soja na Região Nordeste ${ }^{8}$ apresenta expansão pós 1985, destacando o Estado da Bahia, que em 1995 detinha 2,2\% da capacidade de processamento de soja, apesar de ter sido responsável por $4,2 \%$ da produção nacional de soja em grão. O Estado do Maranhão não indicou, em 1995 e 1998, a presença de

\footnotetext{
${ }^{8}$ Apenas o Estado da Bahia possui os dados discriminados.
} 
indústria processadora de soja, apesar de o estado ter sido responsável por $0,6 \%$ e $0,9 \%$, respectivamente, da produção nacional de soja em grão nesses anos.

A partir do que foi exposto nota-se uma evolução diferenciada do processamento industrial da soja no Brasil, definindo as regiões de cerrado do Centro-Oeste e Minas Gerais e de expansão na Bahia e Maranhão como ofertantes líquidas de soja em grão para o mercado interno ou externo.

Partindo dos dados da capacidade instalada de processamento, pode-se calcular as medidas de concentração "Razão de concentração das quatro maiores empresas (CR4)" e "Índice de Hirschman-Herfindahl- (H)". O CR4 mede a participação das 4 maiores empresas na capacidade total de esmagamento da indústria. Conforme Kon (1994), o Índice de Hirschman-Herfindahl mede a participação de cada firma em relação ao tamanho total da indústria levando em consideração todas as firmas da indústria. Quanto mais próximo de um for o Índice de Hirschman-Herfindahl, maior será o nível de concentração do mercado, caracterizando-se como monopólio quando o valor alcançado por $\mathrm{H}$ for igual à unidade.

Primeiramente, ao analisar o mercado nacional, verifica-se uma tendência de concentração apontada pelo CR4 e pelo H. Em 1993, as 4 maiores empresas participaram com $34,4 \%$ da capacidade total de esmagamento da indústria, passando, em 1997, a representar 43,8\% (Tabela 14). Quanto ao Índice de Hirschman-Herfindahl, este também aumenta neste período considerado, indicando uma desigualdade na distribuição da capacidade produtiva entre as empresas. Esta desigualdade da distribuição deve estar ocorrendo em função do crescimento da capacidade produtiva das grandes empresas (como evidenciado na Tabela 12).

Considerando as unidades da Federação, observa-se que existe uma heterogeneidade dos níveis de concentração. No Estado da Bahia, o índice CR4 exibe que quatro empresas são responsáveis pela totalidade da capacidade de esmagamento. Verifica-se, através do índice $\mathrm{H}$, que nesse mesmo estado houve aumento no nível de 
desigualdade, chegando em 1997 a se caracterizar num mercado monopolístico, com apenas uma empresa dominando este mercado.

Tabela 14. Indicadores de concentração na indústria de esmagamento de oleaginosas no Brasil - anos selecionados.

\begin{tabular}{cccrcrcr}
\hline Regiões & Estado & \multicolumn{2}{c}{1993} & \multicolumn{2}{c}{1995} & \multicolumn{2}{c}{ 1997* $^{*}$} \\
\cline { 3 - 8 } & & H & CR4 & H & CR4 & H & CR4 \\
\hline Região & RS & 0,110 & 39,5 & 0,122 & 62,4 & 0,178 & 70,5 \\
Tradicional & SC & 0,363 & 95,1 & 0,368 & 93,4 & 0,436 & 96,6 \\
& PR & 0,058 & 28,6 & 0,067 & 35,9 & 0,087 & 46,3 \\
& SP & 0,116 & 54,7 & 0,145 & 67,7 & 0,107 & 52,3 \\
\hline Região & MT & 0,252 & 96,1 & 0,257 & 89,2 & 0,242 & 87,4 \\
Centro-Oeste & MS & 0,168 & 75,7 & 0,209 & 85,6 & 0,177 & 76,6 \\
e Minas Gerais & GO & 0,180 & 75,6 & 0,225 & 76,5 & 0,186 & 70,5 \\
& MG & 0,382 & 100,0 & 0,349 & 100,0 & 0,363 & 100,0 \\
\hline Região Nordeste & BA & 0,500 & 100,0 & 0,547 & 100,0 & 1,000 & 100,0 \\
\hline Brasil & & 0,049 & 34,4 & 0,045 & 33,2 & 0,082 & 43,8 \\
\hline
\end{tabular}

Fonte: Lazzarini \& Nunes, 1997, p.74-75.

* Plantas da Ceval e da Santista/Bunge consideradas em única empresa, em função do processo de aquisição ocorrido em 1997.

O Estado do Paraná, o qual possui a maior capacidade instalada, é dentre os demais estados brasileiros o que apresenta o menor nível de concentração. Em 1997, já considerando a aquisição das plantas industriais da Ceval pela Santista Alimentos, as quatro maiores empresas detinham $46,3 \%$ da capacidade instalada e o índice $\mathrm{H}$ apresenta o valor de 0,087 , mostrando que a distribuição do mercado está, relativamente a outros estados, mais pulverizada entre as empresas.

Lazzarini \& Nunes (1997) afirmam que, apesar dos diferenteś níveis de concentração existente nos estados brasileiros, na maior parte o mercado relevante a ser considerado compreende também os estados vizinhos. Assim pode-se perguntar: até que ponto torna-se importante analisar a concentração da indústria esmagadora por unidade de Federação, sendo que muitas empresas atuam em vários estados? 
De acordo com Magalhães (1998), o aumento da concentração na indústria de esmagamento nos estados pode se refletir em vantagens competitivas em operar com plantas industriais que possuem uma elevada capacidade de processamento e estão localizadas em regiões com disponibilidade de matéria-prima no volume necessário.

Castro (1993, p.106) aborda a importância da economia de escala na redução de custos em produtos homogêneos, como o caso do farelo e óleo bruto. "Estes mercados, fortemente organizados, são exigentes quanto à qualidade e sensíveis a preços. Desta forma, as empresas dependem acentuadamente de sua estrutura de custos. O acesso à soja produzida em condições competitivas (produtividade e qualidade), relações de compra e venda sistemáticas com produtores agrícolas, a operação de economia de escala na produção e comercialização de produtos, a utilização de tecnologias de processo de produção e uma boa estrutura de armazenamento são fatores que explicam os fatores de liderança de uma empresa".

Os custos unitários de esmagamento se reduzem à medida que aumenta a capacidade industrial de processamento. Através da Tabela 15 pode-se verificar como se dá esta redução de custo conforme o tamanho da planta industrial.

Tabela 15. Economias de escala no processamento de soja: redução de custos esperada de acordo com o aumento no tamanho da planta.

Aumento de escala

De 300 para $600 \mathrm{t} / \mathrm{dia}$

De 600 para $1.000 \mathrm{t} / \mathrm{dia}$

De 1.000 para $1.500 \mathrm{t} / \mathrm{dia}$

De 1.500 para $2.000 \mathrm{t} / \mathrm{dia}$
Redução de custos em relação à escala anterior
$15,0 \%$ $3,5 \%$ $7,0 \%$ $5,6 \%$

Fonte: Lazzarini \& Nunes, 1997, p.80

O aumento da capacidade instalada reduz os custos unitários de produção da indústria, mas por outro lado encontra alguns entraves. Segundo dados da ABIOVE (2000), a capacidade instalada de processamento de oleaginosas em 1998 corresponde a 120.910 t/dia. Considerando a utilização da fábrica por 300 dias/ano e verificando a 
quantidade de soja que foi processada neste mesmo período $(21.100 .000 \mathrm{t})$, conclui-se que o parque industrial tem operado com uma capacidade ociosa em torno de $40 \%$.

Essa alta ociosidade propicia a ineficiência de muitas empresas processadoras de soja no Brasil, pois ultrapassa os padrões recomendados internacionalmente, que se situam de 10 a 15\% (Lazzarini \& Nunes, 1997). 


\section{METODOLOGIA E FONTE DE DADOS}

No capítulo anterior, observou-se que a lavoura de soja e a indústria processadora têm apresentado evoluções distintas nas Regiões Tradicional, Centro-Oeste e Minas Gerais, e Nordeste. Constatou-se, também, que essa evolução não é homogênea dentro de cada região e que há relações entre a modernização da lavoura de soja, a localização e atuação da indústria processadora, o canal de comercialização utilizado e o estímulo de políticas econômicas.

No entanto, o número de variáveis vinculadas a cada um dos tópicos acima indicados é grande e, nesse caso, é difícil, através da análise tabular e gráfica, fazer comparações intertemporais e entre os estados das relações sugeridas. Para esses casos, aconselha-se o uso de técnicas de análise multivariada como a análise fatorial e a de componentes principais. Através da análise fatorial procura-se reduzir um número de variáveis consideradas em um número menor de variáveis hipotéticas (fatores). Esses fatores são uma combinação de variáveis correlacionadas entre si.

\subsection{Análise Fatorial}

A análise fatorial se faz em três etapas ${ }^{9}$. Primeiramente, é determinada a matriz das correlações entre as variáveis originais. Para tanto, considere $L$ observações para os $n$ indicadores, sendo $X_{i j}(\operatorname{com} i=1,2,3, \ldots, n$ e $j=1,2,3, \ldots, L)$ a $j$-ésima observação do $i$-ésimo indicador.

\footnotetext{
${ }^{9}$ Quanto a descrição do método ver Llanillo (1984) e Hoffmann (1999).
} 
A média do $i$-ésimo indicador, ou variável, é: $\bar{X}_{i}=\frac{1}{L} \sum_{j=1}^{L} X_{i j}$

Assim, a padronização dos indicadores é realizada da seguinte maneira:

$$
x_{i j}=\frac{X_{i j}-\bar{X}_{i}}{\sqrt{\sum_{j=1}^{L}\left(X_{i j}-\bar{X}_{i}\right)^{2}}}
$$

Essa transformação faz com que no espaço das $L$ observações, o vetor $\mathbf{x}_{i}$, para cada indicador, tenha módulo igual a $1\left(\sum x_{i j}^{2}=1\right)$.

Assim, na primeira etapa, define-se a matriz das correlações simples entre os indicadores; que é dada por $\mathbf{R}=\mathbf{X X} \mathbf{X}^{\prime}$, onde

$$
\mathbf{X}=\left[\begin{array}{lllc}
x_{11} & x_{12} & \cdots & x_{1 L} \\
x_{21} & x_{22} & \cdots & x_{2 L} \\
\vdots & \vdots & & \vdots \\
x_{n 1} & x_{n 2} & \cdots & x_{n L}
\end{array}\right]=\left[\begin{array}{c}
\mathbf{x}_{1} \\
\mathbf{x}_{2} \\
\vdots \\
\mathbf{x}_{n}
\end{array}\right]
$$

Na segunda etapa, são calculados os fatores necessários para representar as variáveis, que no presente trabalho será realizado pelo método dos componentes principais. $\mathrm{O}$ fator 1 é a combinação linear que extrai a maior percentagem da variância dos indicadores. O fator 2 será a próxima combinação linear que maximizará o percentual da variância restante. Os demais fatores obtidos seguem o mesmo princípio. Deve-se observar que os fatores extraídos são independentes entre si, ou seja, ortogonais (Meyer \& Braga, 1998).

No modelo da análise fatorial, cada indicador $x_{i}$ representa uma combinação linear de $m$ fatores comuns e de um fator específico. Para o $i$-ésimo indicador tem-se: 


$$
x_{i j}=a_{i 1} f_{1 j}+a_{i 2} f_{2 j}+\cdots+a_{i m 1} f_{m j}+u_{i} y_{i j}
$$

ou

$$
x_{i j}=\sum_{p=1}^{m} a_{i p} f_{p j}+u_{i} y_{i j}
$$

Onde:

$f_{p j}$ é o valor do $p$-ésimo fator comum para a $j$-ésima observação, ou seja, valor dos fatores comuns desde que todos os indicadores sejam expressos em função deles;

$a_{i p}$ é coeficiente;

$u_{i}$ é coeficiente;

$y_{i j}$ representa o $j$-ésimo valor do $i$-ésimo fator específico, ou seja, é o valor único que representa a parte não explicada pelos fatores comuns.

Admite-se que todos os fatores são variáveis com média zero e que seus respectivos vetores tem módulo igual a 1 . Assim:

$$
\begin{aligned}
& \sum_{j} f_{p j}=\sum_{j} y_{i j}=0 \\
& \sum_{j} f_{p j}^{2}=\sum_{j} y_{i j}^{2}=1
\end{aligned}
$$

para $p=1, \ldots, m$
$i=1, \ldots, n$.

Representando o modelo de análise fatorial em notação matricial, tem-se:

$$
\mathbf{X}=\mathbf{A F}+\mathbf{U Y}
$$


onde:

$$
\begin{aligned}
& \mathbf{A}=\left[\begin{array}{cccc}
a_{11} & a_{12} & \cdots & a_{1 m} \\
a_{21} & a_{22} & \cdots & a_{2 m} \\
\cdots & \cdots & \cdots & \ldots \\
a_{n 1} & a_{n 2} & \cdots & a_{n m}
\end{array}\right]_{n \times m} \\
& \mathbf{F}=\left[\begin{array}{cccc}
f_{11} & f_{12} & \cdots & f_{1 L} \\
f_{21} & f_{22} & \cdots & f_{2 L} \\
\ldots & \ldots & \ldots & \ldots \\
f_{m 1} & f_{m 2} & \cdots & f_{m L}
\end{array}\right]_{m \times L} \\
& \mathbf{U}=\left[\begin{array}{cccc}
u_{1} & 0 & \cdots & 0 \\
0 & u_{2} & \cdots & 0 \\
\cdots & \cdots & \cdots & \cdots \\
0 & 0 & \cdots & u_{n}
\end{array}\right]_{n \times n} \\
& \mathbf{Y}=\left[\begin{array}{cccc}
y_{11} & y_{12} & \cdots & y_{1 L} \\
y_{21} & y_{22} & \cdots & y_{2 L} \\
\ldots & \ldots & \cdots & \cdots \\
y_{n 1} & y_{n 2} & \cdots & y_{n L}
\end{array}\right]_{n \times L}
\end{aligned}
$$


Onde:

A: matriz dos coeficientes dos fatores comuns;

F: matriz dos fatores comuns, na qual cada linha corresponde a um fator;

U: matriz dos coeficientes dos fatores específicos;

Y: matriz dos fatores específicos.

Admite-se que todos os fatores são ortogonais entre si e com vetores com módulo igual a 1, então, a partir dessas duas pressuposições pode-se definir que:

$\mathbf{F F}^{\prime}=\mathbf{I} m$ (matriz unitária de ordem $m$ )

$\mathbf{Y Y}^{\prime}=\mathbf{I} n$ (matriz unitária de ordem $n$ )

Admite-se, também, que os $m$ fatores comuns são ortogonais com os $n$ fatores específicos, resultando numa matriz de zeros, assim: $\mathbf{F Y} \mathbf{Y}^{\prime}=\mathbf{0}$

Sabe-se que $\mathbf{R}=\mathbf{X X}$

Como $\mathbf{X}=\mathbf{A F}+\mathbf{U Y}$, então:

$$
\begin{aligned}
& \mathbf{R}=(\mathbf{A F}+\mathbf{U Y})\left(\mathbf{F}^{\prime} \mathbf{A}^{\prime}+\mathbf{Y}^{\prime} \mathbf{U}^{\prime}\right)
\end{aligned}
$$

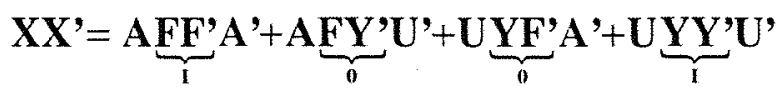

$$
\begin{aligned}
& \mathbf{X X}^{\prime}=\mathbf{A A}^{\prime}+\mathbf{U}^{\prime} \\
& \mathbf{R}=\mathbf{X X}^{\prime}=\mathbf{A A}^{\mathbf{}}+\mathbf{U}^{\mathbf{2}}
\end{aligned}
$$

De acordo com essa relação, para cada elemento da diagonal $\mathbf{R}$ (que é sempre 1), tem-se: 


$$
1=\sum_{j=1}^{L} x_{i j}^{2}=\sum_{p=1}^{m} a_{i p}^{2}+u_{i}^{2}
$$

Os termos do último membro dessa expressão representam as proporções da variância de $x_{i}$ devido aos fatores comuns e aos fatores específicos.

A soma dos quadrados das variáveis de uma linha da matriz das cargas fatoriais denomina-se comunalidade. Corresponde à proporção da variância total de cada variável que é explicada pelo conjunto de fatores. Os valores da comunalidade estão num intervalo de 0 a 1 . Quanto mais próximo de 1 , maior será a contribuição do fator para explicação de determinado indicador. É expressa por:

$$
h_{i}^{2}=\sum_{p=1}^{m} a_{i p}^{2}
$$

A proporção da variância do $i$-ésimo indicador explicado pelo fator específico é $u_{i}^{2}$ e denomina-se especificidade do indicador. Assim:

$$
h_{i}^{2}+u_{i}^{2}=1
$$

Na terceira etapa, os fatores obtidos são submetidos a uma rotação. O objetivo da rotação ortogonal consiste em transformar os fatores obtidos em novos fatores independentes. Com isso, espera-se que os indicadores que tenham correlação mais forte entre si estejam dentro de um mesmo fator e apresentem correlação mais fraca com os demais fatores, facilitando a interpretação dos mesmos. Cabe ressaltar que a rotação altera a parcela de contribuição de cada fator, mas mantém os valores das comunalidades e a proporção da variância explicada pelo conjunto de fatores. O critério utilizado de transformação ortogonal dos fatores será o Varimax.

Na presente pesquisa são analisados 10 estados brasileiros e considerados 12 indicadores de modernização da lavoura da soja para cada ano $(1975,1980,1985$ e 1995). Assim definem-se cinco matrizes de observações que são: 
$\mathbf{X}_{\mathbf{1}}$ a matriz $10 \times 12$ para 1975

$\mathbf{X}_{\mathbf{2}}$ a matriz $10 \times 12$ para 1980

$\mathbf{X}_{\mathbf{3}}$ a matriz $10 \times 12$ para 1985

$\mathbf{X}_{\mathbf{4}}$ a matriz $10 \times 12$ para 1995

Agregando-se as observações referentes aos 4 anos define-se a matriz $40 \times 12$.

$$
\mathbf{X}=\left[\begin{array}{l}
X_{1} \\
X_{2} \\
X_{3} \\
X_{4}
\end{array}\right]
$$

Se fosse feita uma análise fatorial para cada ano (1975, 1980, 1985 e 1995), os fatores não seriam exatamente os mesmos, dificultando as comparações intertemporais. Portanto, para obter uma única medida (único fator) da velocidade do processo de modernização em cada estado, as observações para os 4 anos têm que ser agrupadas. Assim, a matriz das observações, para a aplicação da análise fatorial, será composta por 40 linhas (correspondente aos 10 estados produtores de soja considerando as observações nos 4 cortes temporais: 1975, 1980, 1985 e 1995) e 12 colunas (correspondentes aos indicadores).

Para o processamento dos dados será usado o SAS (Statiscal Analysis System).

\subsection{Indicadores e fonte de dados}

A modernização da agricultura possui um caráter multidimensional, tornando-se necessário um grande número de indicadores para caracterizá-la de forma abrangente. Para Souza (1990, p.177), entende-se por modernização do setor soja no Brasil "o conjunto de mudanças tecnológicas, econômicas e sociais ocorridas na produção, distribuição, processamento e consumo desse grão". Portanto, a modernização se relaciona com variáveis que mensurem o canal de distribuição utilizado, com a localização, importância e modo de atuar das empresas processadoras, pela importância da política econômica e pela importância da cultura no estado. 
Com intuito de mensurar esses aspectos, foram selecionados 12 indicadores. A escolha desses indicadores se fez com base na disponibilidade de dados secundários e levando em consideração as variáveis sugeridas em trabalhos similares (em especial o de Gomes, 1990; e Shikida, 1997). Os valores das 12 variáveis são calculados para cada um dos estados das Regiões Tradicional, Centro-Oeste e Minas Gerais, e Nordeste. Os indicadores são:

Sobre o uso de insumos e técnicas modernas no segmento agrícola

Indicador 1 - percentual da área colhida que utilizou adubação;

Indicador 2 - percentual da área colhida que utilizou defensivos;

$>$ Produtividade agrícola e tamanho médio da lavoura

Indicador 3 - produtividade da soja $(\mathrm{kg} / \mathrm{ha})$;

Indicador 4 - tamanho médio da lavoura de soja.

$>$ Sobre a forma de comercialização

Indicador 5 - percentual da produção de soja entregue à indústria processadora.

$>$ Sobre o financiamento

Indicador 6 - percentual do estado no total de financiamentos destinados ao custeio da soja.

Indicador 7 - percentual do estado no total de financiamentos destinados à comercialização da soja;

Indicador 8 - total de financiamentos (custeio e comercialização) $\div$ área de soja.

> Sobre o segmento processador de soja;

Indicador 9 - percentual do estado na capacidade instalada de processamento de soja do Brasil;

$>$ Sobre o grau de especialização na cultura da soja

Indicador 10 - total da área colhida com soja no estado $\div$ total da área plantada com lavouras temporárias e permanentes no estado: 
Indicador 11 - total da área colhida com soja no estado $\div$ total da área explorada no estado ${ }^{10}$;

Indicador 12 - total da área colhida com soja no estado $\div$ total da área colhida com soja no Brasil.

O quadro 1 indica as fontes dos dados para mensurar os indicadores acima.

Quadro 1. Fonte das informações para os indicadores de modernização na lavoura de soja.

\begin{tabular}{|l|l|}
\hline \multicolumn{1}{|c|}{ Indicadores } & \multicolumn{1}{c|}{ Fonte das informações } \\
\hline $1,2,4,5,10$ e 11 & Censos Agropecuários \\
\hline 3 e 12 & Anuário Estatístico do Brasil \\
\hline 6,7 e 8 & $\begin{array}{l}\text { Crédito Rural - Dados Estatísticos } \\
\text { Anuário Estatístico do Crédito Rural }\end{array}$ \\
\hline 9 & $\begin{array}{l}\text { Williams \& Thompson (1988) } \\
\text { Rizzi \& Paula (1996) } \\
\text { Lazzarini \& Nunes (1997) }\end{array}$ \\
\hline
\end{tabular}

\footnotetext{
${ }^{10} \mathrm{~A}$ área explorada é o somatório das áreas com lavouras permanentes e temporárias, pastagens plantadas e naturais, e matas plantadas e naturais.
} 


\section{MEDIDAS DO GRAU DE MODERNIZAÇÃO DA LAVOURA DA SOJA}

Neste capítulo é obtida uma medida do grau de modernização da lavoura da soja no Brasil e de indicadores que a ela se vinculam, verificando suas evoluções em três regiões de cultivo: Região Tradicional, Região Centro-Oeste e Minas Gerais, e Região Nordeste. Para tanto, utilizou-se os anos de 1975, 1980, 1985 e 1995 para caracterizar a expansão da cultura da soja entre os estados brasileiros. O procedimento adotado foi a análise fatorial pelo método dos componentes principais.

\subsection{Notas sobre os indicadores referente à lavoura da soja}

Encontrou-se dificuldade na obtenção de dados sobre a cultura da soja para os Estados da Bahia e Maranhão. Como esses dois estados tiveram aumento mais expressivo da produção de soja a partir de 1985, o Censo Agropecuário traz informações somente para o ano de 1995. Assim, para os indicadores 1, 2, 4 e 5, nos anos de 1975, 1980 e 1985, foram considerados valores iguais a zero.

Dada essa dificuldade, para as variáveis 10 e 11, que apresentam como numerador a área colhida com soja no estado, a fonte utilizada para os Estados da Bahia e Maranhão foi o Anuário Estatístico do Brasil nos anos de 1975, 1980 e 1985. Para o ano de 1995 na Bahia e Maranhão e para os demais estados (nos anos de 1975, 1980, 1985 e 1995) a fonte utilizada foi o Censo Agropecuário. devido ao denominador dessas variáveis pertencer à mesma fonte.

Outra dificuldade encontrada foi na obtenção de dados para a agroindústria processadora de soja. Considerando a evolução da capacidade instalada de processamento de soja, foram consideradas as informações do ano de 1977 válidas para 
o ano de 1975. Para o ano de 1980, foi feita a média aritmética simples a partir dos valores dos anos de 1977 e 1985.

Para a variável 8 houve a necessidade de uniformizar os valores monetários referentes aos quatro anos considerados na análise fatorial. Os valores foram convertidos para Reais de agosto de 1994, utilizando para deflacioná-los o IGP-DI (Índice Geral de Preços - Disponibilidade Interna) da Fundação Getúlio Vargas.

Outro ponto a ser destacado é quanto aos dados referentes aos Estados de Mato Grosso e Mato Grosso do Sul para o ano de 1975, pois a divisão do antigo Estado do Mato Grosso ocorreu no ano de 1977. Como a produção de soja encontrava-se na região sul do Estado de Mato Grosso, pertencente atualmente ao Estado do Mato Grosso do Sul, os dados de 1975 foram considerados para este último estado.

O Distrito Federal não foi considerado na análise fatorial em função da falta de informações para essa Unidade da Federação. Pelo fato do Distrito Federal representar em torno de $1 \%$ da produção da Região Centro-Oeste e Minas Gerais, a omissão dessa observação não produzirá alterações substanciais nos resultados obtidos.

Cumpre ressaltar que não foi possível a obtenção de dados sobre o financiamento destinado ao capital de giro e capital fixo da agroindústria processadora de soja (ver item 2.2.1) e também de dados que pudessem medir a mecanização da cultura da soja, pois as máquinas agrícolas não são necessariamente específicas para essa cultura, podendo ser utilizadas em outras lavouras temporárias. Através da Tabela 16 pode-se verificar a matriz de dados que foi utilizada para a análise fatorial. 
Tabela 16. Matriz de dados para a Análise Fatorial

\begin{tabular}{|c|c|c|c|c|c|c|c|c|c|c|c|}
\hline \multirow{3}{*}{$\begin{array}{c}\text { Variá } \\
\text { Vel }\end{array}$} & \multirow[t]{3}{*}{ Ano } & \multicolumn{10}{|c|}{ Regiões } \\
\hline & & \multicolumn{4}{|c|}{ Região Tradicional } & \multicolumn{4}{|c|}{ Regiāo Centro-Oeste e Minas Gerais } & \multicolumn{2}{|c|}{ Região Nordeste } \\
\hline & & $\mathrm{RS}$ & $\mathrm{SC}$ & PR & $S P$ & MT & MS & $\mathrm{GO}$ & MG & BA & MA \\
\hline 1 & 75 & 72,8 & 34,3 & 72.7 & 98,6 & 0.0 & 75.7 & 98,3 & 96,5 & 0,0 & 0,0 \\
\hline 1 & 80 & 86.7 & 57,1 & 93,5 & 99,4 & 99.0 & 96,4 & 99,8 & 99,3 & 0.0 & 0,0 \\
\hline 1 & 85 & 84,1 & 61,0 & 94,8 & 98,9 & 98.6 & 96,0 & 99,4 & 98,7 & 0,0 & 0,0 \\
\hline 1 & 95 & 92,0 & 95,7 & 97,3 & 99,4 & 98.6 & 97,7 & 99,7 & 97,9 & 98,4 & 88,5 \\
\hline 2 & 75 & 72,7 & 24,7 & 78.2 & 95,9 & 0.0 & 88,2 & 83,3 & 86,6 & 0,0 & 0,0 \\
\hline 2 & 80 & 70.0 & 40,5 & 92,1 & 96,9 & 83.0 & 97,1 & 94,3 & 94,8 & 0,0 & 0.0 \\
\hline 2 & 85 & 74,5 & 46.8 & 92,9 & 94,4 & 92.2 & 94,4 & 95,8 & 93.4 & 0,0 & 0,0 \\
\hline 2 & 95 & 86,0 & 91,4 & 72,2 & 96,2 & 95.9 & 96,9 & 97,2 & 92,3 & 98,7 & 85,7 \\
\hline 3 & 75 & 1506,0 & 1292,0 & 2221,0 & 1733,0 & 0.0 & 1403.0 & 1320,0 & 1153,0 & 937,0 & 0,0 \\
\hline 3 & 80 & 1439,0 & 1381,0 & 2240,0 & 1960,0 & 1664,0 & 1639,0 & 1852,0 & 1783,0 & 1167,0 & 1200,0 \\
\hline 3 & 85 & 1570,0 & 1342,0 & 2009,0 & 1926,0 & 2082.0 & 1957,0 & 1847,0 & 1974,0 & 1200,0 & 1109,0 \\
\hline 3 & 95 & 1945,0 & 2177,0 & 2581.0 & 2237.0 & 2364.0 & 2188,0 & 1914.0 & 1997.0 & 2280,0 & 1852,0 \\
\hline 4 & 75 & 11,9 & 4,7 & 11,0 & 61,0 & 0.0 & 16,9 & 96,4 & 59,6 & 0,0 & 0,0 \\
\hline 4 & 80 & 15,0 & 7,2 & 21,2 & 63,7 & 209.3 & 93.3 & 138.5 & 107.6 & 0,0 & 0,0 \\
\hline 4 & 85 & 14,5 & 6,8 & 24,3 & 63.5 & 270.7 & 142.9 & 173,3 & 116,7 & 0,0 & 0,0 \\
\hline 4 & 95 & 16,9 & 16,8 & 32.4 & 64,7 & 633.6 & 176,9 & 248,0 & 172,9 & 475,4 & 338.7 \\
\hline 5 & 75 & 7,2 & 7.7 & 12,4 & 42,6 & 0.0 & 14.6 & 25,3 & 39,3 & 0,0 & 0,0 \\
\hline 5 & 80 & 12,4 & 20,1 & 12.7 & 56,1 & 58.5 & 31,2 & 60,8 & 53,7 & 0,0 & 0,0 \\
\hline 5 & 85 & 5,7 & 23,9 & 12,0 & 43,2 & 33.4 & 25,3 & 38.4 & 49,9 & 0,0 & 0,0 \\
\hline 5 & 95 & 19,8 & 16,8 & 15,6 & 34,9 & 40.2 & 34,7 & 50,9 & 47,1 & 71,1 & 28,6 \\
\hline 6 & 75 & 47,2 & 1,3 & 36,7 & 11,0 & 0.0 & 1,9 & 0,5 & 1,3 & 0,0 & 0,0 \\
\hline 6 & 80 & 42,5 & 2.8 & 28.8 & 10,3 & 1.2 & 9.2 & 3,1 & 1,9 & 0,0 & 0,0 \\
\hline 6 & 85 & 26,9 & 1,5 & 24,6 & 6,3 & 14,3 & 12,1 & 9,1 & 3,8 & 1,1 & 0,1 \\
\hline 6 & 95 & 20,3 & 1,8 & 34,4 & 6,7 & 14.7 & 7,0 & 8,2 & 4,5 & 1,9 & 0,4 \\
\hline 7 & 75 & 39,4 & 4,0 & 44,0 & 10,7 & 0.0 & 0,5 & 0.5 & 0,8 & 0,0 & 0.0 \\
\hline 7 & 80 & 39,0 & 5,7 & 35,6 & 13,8 & 0,4 & 3,6 & 1,0 & 0,7 & 0,2 & 0,0 \\
\hline 7 & 85 & 29,6 & 10,1 & 34,3 & 12,3 & 1.2 & 4,0 & 3.2 & 4,0 & 0,1 & 0,0 \\
\hline 7 & 95 & 4,6 & 0,3 & 45,3 & 0,4 & 29.6 & 11.2 & 7,0 & 1,3 & 0,2 & 0,0 \\
\hline 8 & 75 & 594,2 & 326,3 & 1067,0 & 1187,9 & 0,0 & 261,6 & 407,9 & 591,4 & 1074,8 & 0,0 \\
\hline 8 & 80 & 526,0 & 385,3 & 666,7 & 1064,1 & 630,8 & 440,9 & 467,1 & 459,5 & 2496,0 & 696,1 \\
\hline 8 & 85 & 292,6 & 310,2 & 470,3 & 585,8 & 560,8 & 307,2 & $414 r^{1}$ & 334,6 & 568,8 & 301,1 \\
\hline 8 & 95 & 37,9 & 48,5 & 91,7 & 70,7 & 38.3 & 39,8 & 42,0 & 41,7 & 22,1 & 22,3 \\
\hline 9 & 75 & 38,6 & 5,2 & 29,8 & 24,9 & 0.0 & 0,0 & 0,0 & 1,4 & 0.0 & 0.0 \\
\hline 9 & 80 & 36,8 & 7,6 & 34,0 & 19,4 & 0.0 & 0,7 & 0,6 & 0,9 & 0,0 & 0,0 \\
\hline 9 & 85 & 36,0 & 8,6 & 35,8 & 17,1 & 0.0 & 1.0 & 0.8 & 0.7 & 0,0 & 0,0 \\
\hline 9 & 95 & 24.9 & 4,4 & 30,4 & 11.7 & 7.2 & 6.0 & 7,7 & 3,7 & 2,1 & 0,0 \\
\hline 10 & 75 & 53,9 & 18,4 & 28,7 & 6,7 & 0 & 9,6 & 2.4 & 1,2 & 0 & 0 \\
\hline 10 & 80 & 56,3 & 23,7 & 34,1 & 8,2 & 3,6 & 37 & 6,6 & 3,1 & 0,1 & 0 \\
\hline 10 & 85 & 54,8 & 21,6 & 34,3 & 7,2 & 38,6 & 50,4 & 20,5 & 6,8 & 1,5 & 0,6 \\
\hline 10 & 95 & 42,7 & 10,7 & 44,3 & 7,5 & 59.1 & 53,9 & 39,7 & 10,6 & 9,1 & 7,6 \\
\hline 11 & 75 & 14,8 & 4,8 & 12.5 & 1,8 & 0.0 & 0,5 & 0,2 & 0,1 & 0,0 & 0,0 \\
\hline II & 80 & 17.1 & 7,0 & 14,6 & 2.6 & 0.2 & 2,2 & 0,5 & 0,4 & 0,0 & 0.0 \\
\hline $\mathfrak{1}$ & 85 & 16,6 & 6.5 & 14,0 & 2,5 & 2.5 & 3,4 & 2,2 & 0,9 & 0,2 & 0,1 \\
\hline II & 95 & 12,1 & 2.9 & 15.5 & 2.4 & 3.8 & 2,6 & 3.4 & 1,2 & 1,4 & 0,7 \\
\hline 12 & 75 & 53,5 & 6,2 & 28,0 & 6,7 & 0,0 & 3,3 & 1,0 & 1.3 & 0,0 & 0,0 \\
\hline 12 & 80 & 45.4 & 5,9 & 27,5 & 6,4 & 0.8 & 9,2 & 2,8 & 1.9 & 0,0 & 0,0 \\
\hline 12 & 85 & 35,8 & 4,1 & 21,6 & 4,9 & 7,8 & 12,9 & 7,2 & 4,4 & 0,6 & 0,1 \\
\hline 12 & 95 & 25,8 & 1,7 & 18,9 & 4,5 & 19.9 & 8,9 & 9,6 & 5,1 & 4,0 & 0,8 \\
\hline
\end{tabular}

Fonte: Ver Quadro 1 e Anexo. 


\subsection{Resultados da Análise Fatorial}

Utilizando a matriz 40×12, referente aos 12 indicadores relacionados à lavoura da soja, observados nos 10 estados brasileiros nos anos de 1975, 1980, 1985 e 1995, realizou-se a análise fatorial pelo método dos componentes principais. A matriz de correlações entre os indicadores apresentou 3 raízes características maiores que 1 , na qual o primeiro fator capta $47,56 \%$ da variância total das variáveis, cabendo aos 2 fatores seguintes $29,61 \%$ e $8,81 \%$, respectivamente, dessa variância. Neste trabalho, a análise fatorial foi realizada extraindo os 3 fatores com raízes características maiores que 1, possibilitando captar uma proporção significativa $(85,99 \%)$ da variância total dos doze indicadores originais (Tabela 17).

Tabela 17. Valores das raízes características

\begin{tabular}{lllll}
\hline \multicolumn{1}{c}{ Itens } & Fator 1 & Fator 2 & Fator 3 & Fator 4 \\
\hline Raiz característica & 5,7078 & 3,5536 & $\mathbf{1 , 0 5 6 9}$ & 0,6548 \\
Diferença & 2,1542 & 2,4967 & 0,4021 & 0,3255 \\
Proporção & 0,4756 & 0,2961 & 0,0881 & 0,0546 \\
Cumulativa & 0,4756 & 0,7718 & $\mathbf{0 , 8 5 9 9}$ & 0,9144 \\
\hline
\end{tabular}

Fonte: resultados da pesquisa

Após a rotação pelo método Varimax, que possibilita a melhor interpretação dos fatores, obtiveram-se os coeficientes de correlação entre cada fator e cada um dos doze indicadores, isto é, as cargas fatoriais, as quais são apresentadas na Tabela 18. As cargas fatoriais acima de 0,60 , em valor absoluto, que expressam a forte associação entre o fator e o indicador, estão destacadas em negrito ${ }^{11}$.

Na última coluna da Tabela 18 observam-se os valores das comunalidades, que é a proporção da variância de cada indicador explicada pelo conjunto de fatores. E, na

\footnotetext{
${ }^{11}$ Para estabelecer o valor, em módulo. de 0,60 da carga fatorial teve-se como referência os trabalhos de Gomes (1990), Hoffmann (1992), Figueiredo (1996) e Shikida (1997).
} 
última linha da Tabela 18 apresentam-se as proporções da variância total explicada por cada fator, após a rotação ${ }^{12}$.

Tabela 18. Cargas fatoriais de 3 fatores e comunalidades na análise dos 12 indicadores relacionados à cultura de soja na Região Tradicional, na Região CentroOeste e Minas Gerais, e na Região Nordeste do Brasil - anos selecionados

\begin{tabular}{|c|c|c|c|c|}
\hline Variáveis & $\begin{array}{c}\text { Carga } \\
\text { Fatorial para } \\
\text { F1 }\end{array}$ & $\begin{array}{c}\text { Carga } \\
\text { Fatorial para } \\
\text { F2 }\end{array}$ & $\begin{array}{c}\text { Carga } \\
\text { fatorial para } \\
\text { F3 }\end{array}$ & Comunalidade \\
\hline 1 - \% da área colhida de soja que utilizou adubação no estado & 0.24540 & 0,91912 & $-0,10747$ & 0,916554 \\
\hline 2 - \% da área colhida de soja que utilizou defensivos no estado & 0.21641 & 0,92707 & $-0,09678$ & 0,615667 \\
\hline 3 - Produtividade agrícola da soja no estado( $\mathrm{kg} / \mathrm{ha})$ & 0.32396 & $\mathbf{0 , 8 1 8 2 7}$ & $-0,00845$ & 0,774583 \\
\hline 4- Tamanho médio da lavoura de soja no estado & -0.19601 & 0,62248 & $-0,44852$ & 0,627075 \\
\hline $\begin{array}{l}5 \text { - \% da produção de soja no estado entregue à indústria } \\
\text { processadora }\end{array}$ & -0.30695 & $\mathbf{0 , 8 8 0 9 7}$ & $-0,03273$ & 0,871397 \\
\hline $\begin{array}{l}6 \text {-\% do estado no total de financiamentos destinados ao } \\
\text { custeio da soja }\end{array}$ & 0,96595 & 0,09647 & 0,05533 & 0,945423 \\
\hline $\begin{array}{l}\text { 7. \% do estado no total de financiamentos destinados a } \\
\text { comercialização da soja }\end{array}$ & 0.92642 & 0,07690 & 0,07818 & 0,870272 \\
\hline $\begin{array}{l}8 \text { - Total dos financiamentos de custeio e comercialização da } \\
\text { soja no estado } \div \text { hectares de soja no estado }\end{array}$ & -0.00382 & $-0,13225$ & 0,91400 & 0,852896 \\
\hline $\begin{array}{l}9 \text { - \% do estado na capacidade instalada de processamento } \\
\text { industrial de soja no Brasil }\end{array}$ & 0,92598 & 0,06631 & 0,19427 & 0,899581 \\
\hline $\begin{array}{l}10-\text { Total da área colhida com soja no estado } \div \text { total da área } \\
\text { plantada com lavouras temporárias e permanentes no estado }\end{array}$ & 0.78171 & 0,21687 & $-0,37150$ & 0,796118 \\
\hline $\begin{array}{l}11 \text { - Total da área colhida com soja no estado } \div \text { total da área } \\
\text { explorada no estado }\end{array}$ & 0.96773 & $-0,01960$ & $-0,01292$ & 0,937054 \\
\hline $\begin{array}{l}\text { 12- Total da área colhida com soja no estado } \div \text { total da área } \\
\text { colhida com soja no Brasil }\end{array}$ & 0.95223 & 0,04302 & $-0,05464$ & 0,911583 \\
\hline \% da variância & 45,39 & 30,19 & 10,38 & \\
\hline
\end{tabular}

Fonte: Resultados da pesquisa

${ }^{12}$ A rotação não altera os valores da comunalidade, mas altera a proporção da variância total associada a cada fator. 
Observa-se que o primeiro fator (F1) está positivo e fortemente correlacionado com os indicadores $6,7,9,10,11$, e 12. Os indicadores 9 (percentual do estado na capacidade instalada de processamento industrial da soja no Brasil), 10 (total da área colhida com soja no estado $\div$ total de área plantada com lavouras temporárias $\mathrm{e}$ permanentes no estado), 11 (total da área colhida com soja no estado $\div$ total de área explorada no estado) e 12 (total da área colhida com soja no estado $\div$ total de área colhida com soja no Brasil) fazem o F1 ser uma medida de importância da lavoura e da capacidade instalada de processamento da soja em cada estado. A soja em grão tem pouco valor como produto alimentício ou mesmo para outros usos. O mercado da soja gira em torno de seus derivados: óleo e a proteína na forma de farelo. Dessa maneira, sendo a soja um produto voltado para o processamento, o crescimento da capacidade instalada de processamento acompanhou a expansão da cultura da soja. A associação desse fator com os indicadores 6 (proporção do estado no total de financiamentos destinados ao custeio da lavoura de soja) e 7 (proporção do estado no total de financiamentos destinados à comercialização da lavoura de soja) evidencia a importância do crédito governamental, em cada estado, como principal instrumento de política agrícola, apoiando o desenvolvimento e concentração da cultura da soja entre as regiões do Brasil.

O segundo fator (F2) apresenta forte associação positiva com as variáveis 1 (percentual da área colhida de soja que utilizou adubação), 2 (percentual da área colhida de soja que utilizou defensivos), 3 (produtividade da soja), 4 (tamanho médio da lavoura) e 5 (percentual da produção da soja no estado entregue à indústria processadora). Dada as características desses indicadores, o Fator 2 está medindo a modernização da lavoura da soja em cada estado. Acredita-se que essa modernização esteja associada ao tamanho médio da lavoura e à integração da lavoura com a indústria processadora.

O Fator $3\left(\mathrm{~F}_{3}\right)$ pode ser denominado como "utilização de crédito para cada hectare da cultura da soja", por apresentar correlação positiva e forte com o indicador 
8 (total dos financiamentos de custeio e comercialização da soja no estado $\div$ total da área colhida de soja no estado). Apesar desse fator representar apenas $10,4 \%$ da variância total dos indicadores (após a rotação), ele representa a intensidade do crédito rural por área cultivada com soja em cada estado e propicia a análise da importância do financiamento oficial no fomento ao desenvolvimento dessa cultura.

Nota-se que o valor da carga fatorial entre o indicador 8 e o Fator 2 obteve valor negativo $(-0,13225)$. Isto, a princípio é estranho pois a literatura associa a modernização da agricultura brasileira com a disponibilidade e o subsídio do crédito rural (ver, por exemplo, Shirota, 1988). Como a análise fatorial até aqui apresentada agrega anos distintos, pode-se pensar que este resultado estaria sendo influenciado pelos dados mais recentes. Isto porque os recursos governamentais destinados ao financiamento da agricultura reduziram-se significativamente na década de 80 (mais especificamente pós 1985), sem considerar o fim do subsídio governamental, na qual a taxa de juros vigente era sempre inferior a taxa de inflação da mesma época ${ }^{13}$.

Para verificar se na década de 70 e 80 houve associação positiva entre disponibilidade de crédito e modernização da lavoura de soja, optou-se por fazer uma análise fatorial para cada ano, ou seja 1975, 1980, 1985 e 1995 para verificar se o valor da carga fatorial entre o indicador 8 com o Fator 2, não está sendo influenciado pela expressiva redução da intensidade do crédito pós 1985 (captada pelos valores do ano de 1995).

Em todos os anos a carga fatorial obtida entre o indicador 8 (total dos financiamentos de custeio e comercialização da soja $\div$ hectares de soja no estado) e o Fator 2 (modernização da lavoura da soja) foi baixa, apresentando o menor valor em 1995 (Apêndice 2).

Alternativamente foi feita uma análise fatorial considerando uma nova matriz de

\footnotetext{
${ }^{13}$ Para uma abordagem mais detalhada sobre a evolução do crédito rural no Brasil ver Shirota (1988), Barros \& Araújo (1991) e Nuevo (1996).
} 
dados, em razão de se ter utilizado zeros para os estados que não tinham informações. Isto pode estar influenciando os resultados obtidos e expressos na Tabela 18. Para tanto, foram utilizadas 456 observações (não mais 480 observações), pois eliminou-se, os Estados do Mato Grosso e Maranhão em 1975 em decorrência de não haver registro de produção de soja nestes estados. Foram utilizadas estimativas, porém não oficiais, para os valores das variáveis 1, 2 e 4 em 1975 para Bahia, e, em 1980 e 1985 para Bahia e Maranhão (Apêndice 3).

Entre os resultados obtidos para cada ano, somente em 1985 o valor da carga fatorial representou associação entre o indicador 8 e o Fator 2, sendo o valor obtido de 0,66985 (Apêndice 3). Isso explica que a soja se modernizou mais pelo emprego de tecnologia no início dos anos 80 , refletindo a pequena atuação do crédito oficial na modernização da lavoura da soja. Quando se realiza a análise fatorial considerando todos os anos (1975, 1980, 1985 e 1995) e novos dados, obtêm-se valores similares aos da Tabela 18, não proporcionando alterações na interpretação do indicador 8 e o F2 (Apêndice 4).

Portanto, pode-se considerar os resultados da Tabela 18 como representativos da realidade em estudo.

Através da Tabela 19 verifica-se os valores dos três fatores (F1, F2 e F3) para os dez estados brasileiros em 1975, 1980, 1985 e 1995. 
Tabela 19. Valores dos três fatores relacionados à cultura da soja na Região Tradicional, na Região Centro-Oeste e Minas Gerais, e na Região Nordeste do Brasil anos selecionados.

\begin{tabular}{|c|c|c|c|c|c|c|c|c|c|c|c|c|}
\hline & \multicolumn{4}{|c|}{ Fator 1} & \multicolumn{4}{|c|}{ Fator 2} & \multicolumn{4}{|c|}{ Fator 3} \\
\hline & 1975 & 1980 & 1985 & 1995 & 1975 & 1980 & 1985 & 1995 & 1975 & 1980 & 1985 & 1995 \\
\hline RS & 35 & 2,401 & 1,948 & 1,007 &, 594 & $-0,490$ & $-0,540$ & $-0,026$ & 0,088 & $-0,056$ & $-0,499$ & $-0,736$ \\
\hline SC & 212 & $-0,080$ & $-0,106$ & $-0,410$ & $-1,152$ & $-0,667$ & $-0,562$ & 0,268 & $-0,435$ & $-0,227$ & $-0,250$ & $-0,327$ \\
\hline PR & 1,711 & 1,675 & 1,522 & 1,824 & 0,066 & 0,216 & 0,097 & 0,148 & 1,521 & 0,765 & 0,397 & $-0,294$ \\
\hline SP & $-0,092$ & $-0,149$ & $-0,209$ & $-0,348$ & 0,848 & 1,108 & 0,771 & 0,673 & 2,004 & 1,841 & 0,894 & $-0,095$ \\
\hline MT & - & $-0,941$ & $-0,200$ & 0,453 & - & 0,952 & 0,795 & 1,181 & - & 0,489 & $-0,360$ & $-2,088$ \\
\hline MS & $-0,569$ & $-0,175$ & 0,091 & 0,077 & $-0,198$ & 0,398 & 0,403 & 0,651 & $-0,215$ & $-0,280$ & $-0,808$ & $-1,176$ \\
\hline GO & $-0,767$ & $-0,807$ & $-0,382$ & $-0,118$ & 0,168 & 1,037 & 0,699 & 0,857 & 0,066 & 0,394 & $-0,131$ & $-1,054$ \\
\hline MG & $-0,808$ & $-0,823$ & $-0,654$ & $-0,589$ & 0,321 & 0,885 & 0,860 & 0,789 & 0,556 & 0,444 & 0,169 & $-0,507$ \\
\hline BA & $-0,743$ & $-0,776$ & $-0,671$ & $-0,890$ & $-1,577$ & $-1,117$ & $-1,595$ & 1,581 & 0,900 & 3,405 & 0,063 & $-0,954$ \\
\hline MA & - & $-0,717$ & $-0,698$ & $-0,794$ & - & $-1,557$ & $-1,699$ & 0,513 & - & 0,306 & $-0,406$ & $-1,065$ \\
\hline Média & 0,131 & $-0,039$ & 0,063 & 0.021 & $-0,264$ & 0,076 & $-0,076$ & 0.663 & 0,560 & 0,708 & $-0,093$ & $-0,830$ \\
\hline & & & & & & & & & & & & \\
\hline (20̃ & 1,275 & 1,152 & 0,924 & 0.858 & 0,802 & 0,972 & 0,978 & 0,481 & 0,860 & 1,124 & 0,492 & 0,578 \\
\hline
\end{tabular}

Fonte: resultados da pesquisa

Nota: foram desconsiderados os valores dos Fatores 1, 2 e 3 no ano de 1975 para os Estados de Mato Grosso e Maranhão, em razão de não haver registro de produção de soja nestes estados.

Ao analisar o Fator 1 , que indica a importância da lavoura e da capacidade instalada de processamento da soja, observa-se que na Região Tradicional houve redução dos valores do F1 para o período considerado, exceto para o Estado do Paraná, que apesar de pequenas oscilações na década de 80, não mostrou grandes alterações no período como um todo (1975 a 1995). Este comportamento do Fl na Região Tradicional pode ser explicado pela migração dos produtores da região sul do País para a região dos cerrados, em busca de terras mais baratas. Mas apesar da expansão da soja para outras regiões do Brasil, a Região Tradicional é de grande importância para a produção de soja no Brasil. Deve-se ressaltar que os estados que mais contribuem para esse resultado são o Paraná e o Rio Grande do Sul.

Os valores de F1 para Região Centro-Oeste e Minas Gerais, aumentaram de 1975 a 1995. A expansão da cultura da soja nessa região, ${ }^{14}$ principalmente na década de 80 ,

${ }^{14}$ A cultura da soja nessa região teve inserção na década de 70 através de programas nacionais de desenvolvimento de atividades agropecuárias, incentivado pelo crédito rural e pelo desenvolvimento de pesquisas, principalmente através da Embrapa, voltadas à agricultura nos cerrados. 
seguido pela instalação do parque processador de soja, reflete a evolução diferenciada da cultura da soja entre as regiões do Brasil (verificar Capítulo 2).

Nos Estados da Bahia e Maranhão, mesmo com o maior aumento da área e produção a partir da metade da década de 80 , a cultura da soja é relativamente pequena em relação a produção da soja nas outras regiões do Brasil. A capacidade de processamento, através dos dados obtidos, está presente apenas no Estado do Bahia. Essa recente expansão não foi captada pelos valores obtidos no F1 para a Região Nordeste. Observa-se que no período 1985/95, através dos valores do Fator 1, houve um retrocesso na concentração da cultura da soja e na sua capacidade instalada de processamento, não refletindo a evolução da cultura na Região Nordeste para esse período (como visto no Capítulo 2). Isto pode ser explicado pela utilização de zeros para as variáveis 1, 2 e 4 em 1975, 1980 e 1985, pois quando se utilizou estimativas alternativas houve aumento dos valores do F1 no período 1985/95. Mesmo assim esse aumento foi pequeno. Uma das justificativas para tal comportamento é o fato de se estar trabalhando com dados referentes aos estados e não com dados por microrregião. A cultura da soja na Bahia encontra-se localizada no oeste do estado, na Região de Barreiras; o mesmo acontece no Estado do Maranhão onde a cultura concentra-se na Região de Balsas. Dessa maneira, ao considerar as variáveis 10 (total da área colhida com soja no estado $\div$ total de área plantada com lavouras temporárias e permanentes no estado) e 11 (total da área colhida com soja no estado $\div$ total de área explorada no estado) para todo o estado pode-se ofuscar a expansão existente em áreas dentro do estado.

Através dos valores do Fator 2 verifica-se a modernização progressiva da cultura da soja nos estados produtores de 1975 a 1995 (exceto São Paulo). A média obtida desse fator, para todos estados analisados, passou de $-0,26$ em 1975 para 0,08 em 1980, e apesar da pequena redução no ano de $1985(-0,08)$ chegou ao valor médio de 0,66 em 1995. 
Paula \& Favaret Filho (1998) ressaltam a importância das pesquisas, em especial as realizadas pela Embrapa (Empresa Brasileira de Pesquisa Agropecuária) contribuindo para maior rentabilidade da soja, em função do melhor conhecimento das terras do cerrado e através do lançamento de novas variedades, manejo de solo e pragas para a região sul.

No terceiro fator (F3), "utilização de crédito para cada hectare da lavoura da soja", observa-se a redução dos valores de F3 no período de 1975 a 1995 (exceto para os Estados de Goiás e Bahia que apresentam reduções pós 1980) expressando a redução de crédito oficial perante a expansão da lavoura da soja entre os estados brasileiros.

Considerando que os fatores são independentes entre si, pode-se verificar, graficamente, a evolução diferenciada da lavoura da soja entre as regiões do Brasil, verificando o desempenho dos fatores. Nas Figuras 8, 9, 10 e 11 verifica-se o comportamento inverso entre F1 e F2 na Região Tradicional, ou seja, apesar do fator "medida da importância da lavoura e da capacidade instalada de processamento da soja" indicar perda de importância relativa da Região Tradicional no contexto nacional, a lavoura da soja continuou a se modernizar nessa região (crescimento do Fator 2).

O Estado do Paraná foi o único estado na Região Tradicional que apresentou valores positivos para esses dois fatores, ou seja, tanto a concentração da lavoura da soja e capacidade instalada de processamento quanto a modernização da lavoura da soja encontram-se, relativamente, elevados. Os Estados do Rio Grande do Sul e Santa Catarina apresentaram comportamento semelhante, no qual destaca-se o avanço significativo de F2, mostrando que mesmo com a expansão da cultura da soja para outras regiões, a Região Tradicional de cultivo da soja continuou se modernizando. O Estado de São Paulo é o único que difere na evolução do Fator 2, apresentado aumento de 1975 a 1980 e reduções de 1980 a 1995. 

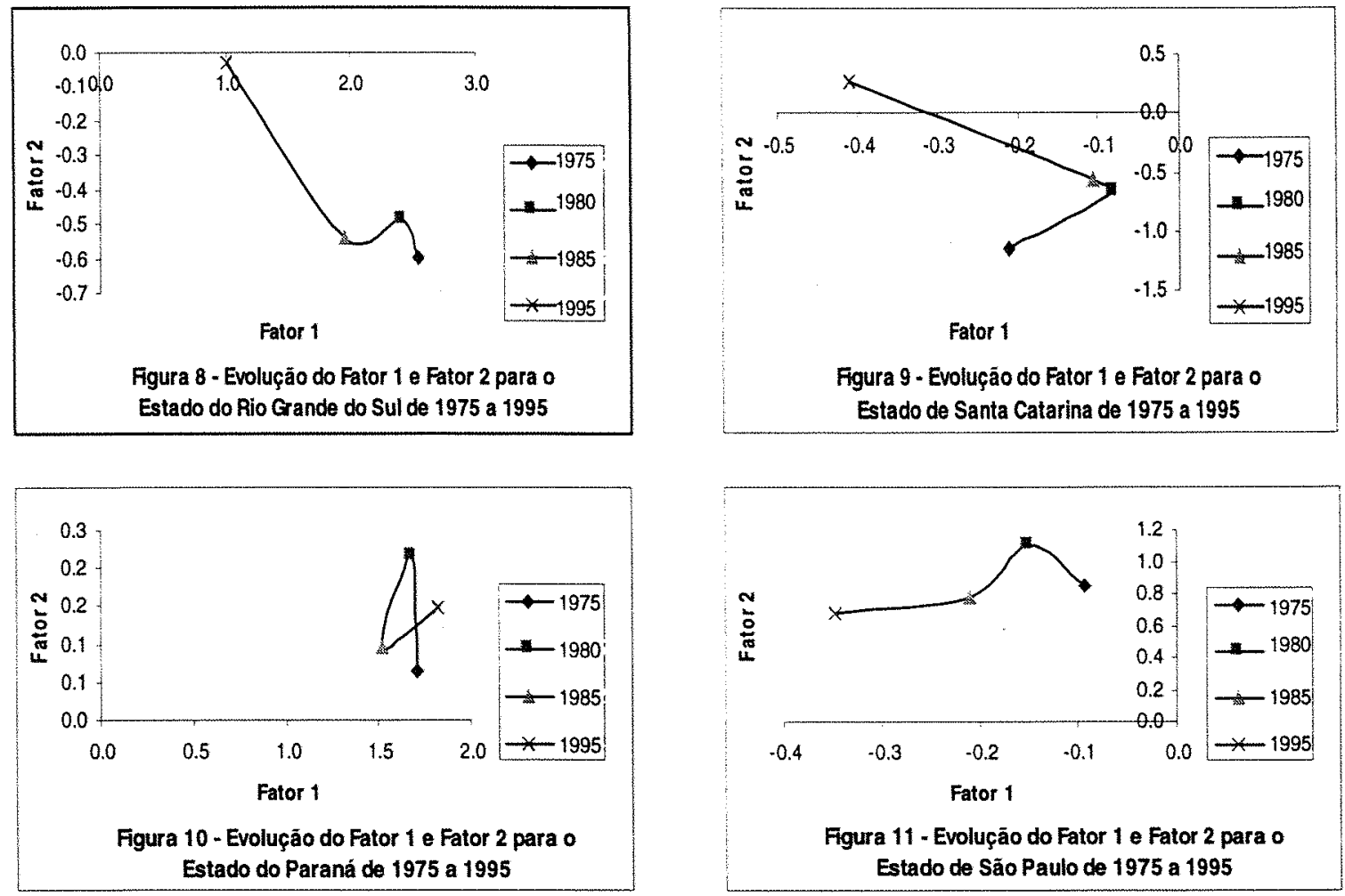

$\mathrm{Na}$ Região Centro-Oeste e Minas Gerais, ambos fatores, F1 e F2, cresceram entre 1975 e 1995 (Figuras 12, 13, 14 e 15). Os Estados de Mato Grosso, Mato Grosso do Sul, Goiás e Minas Gerais (este último em menor proporção) apresentaram aumento do F1, demonstrando o avanço da cultura da soja na região dos cerrados, principalmente a partir da década de 80. Verificou-se níveis bem elevados de F2, entre 1975 e 1980, apresentando oscilações para o restante do período. Mesmo com o desenvolvimento de novas cultivares de soja, para regiões de baixa latitude, deve-se considerar que o incremento de novas áreas plantadas com soja pode reduzir a produtividade global. Isto pode estar influenciando essa redução captada pelo F2 de 1980 para 1985 De modo geral, pode-se colocar que houve maior concentração da cultura da soja e consequentemente do processamento do grão associado a modernização da lavoura da soja para essa região. 

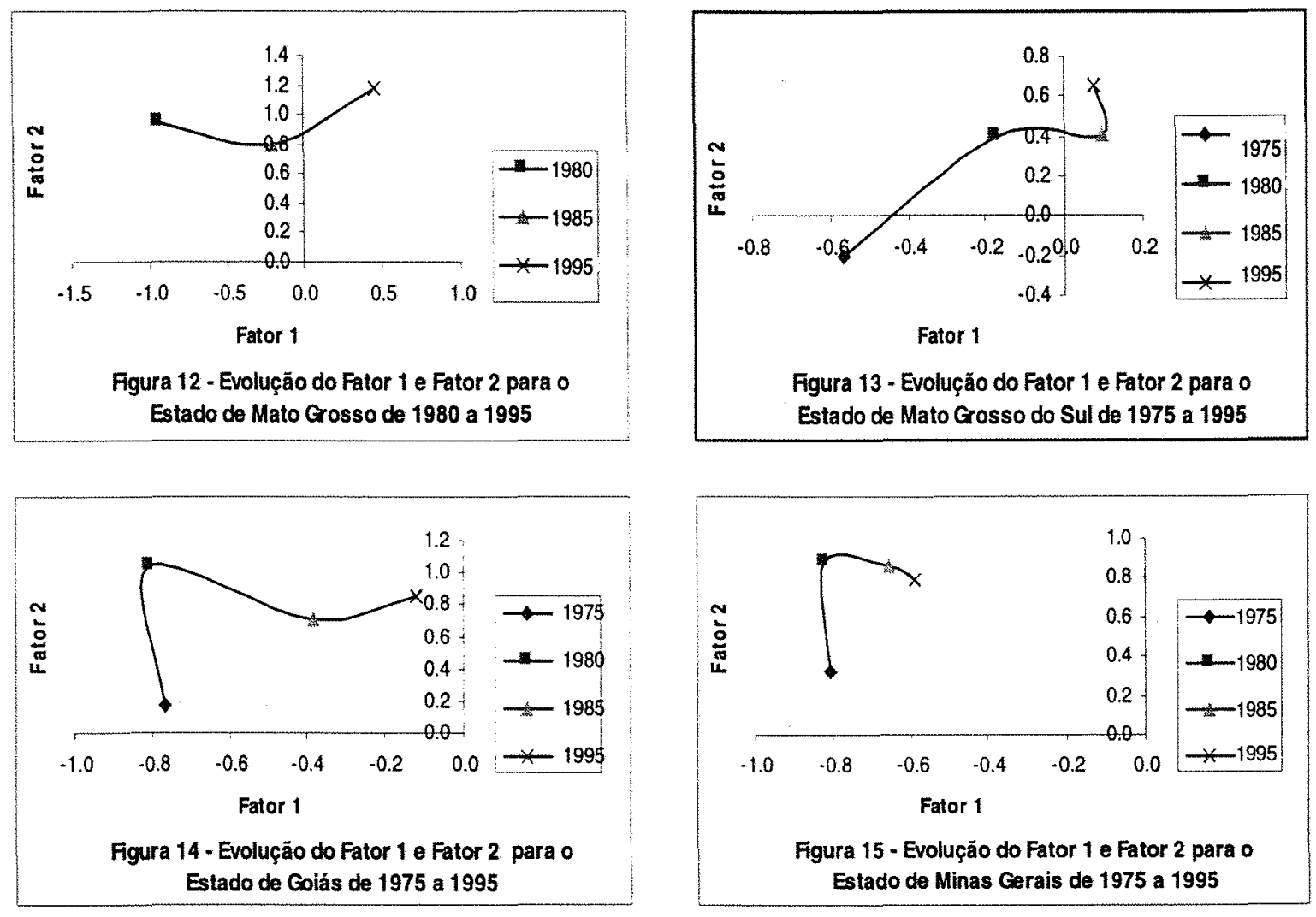

As Figuras 16 e 17 apresentam desempenhos opostos entre os fatores F1 e F2 nos Estados da Bahia e Maranhão, em especial no período de 1985 a 1995. Conforme visto anteriormente o Fator 1 apresenta um comportamento atípico do esperado e que pode ser visualizado através das Figuras 16 e 17. No entanto, o Fator 2 apresenta aumento significativo na modernização da cultura da soja, após 1985, para essa região.
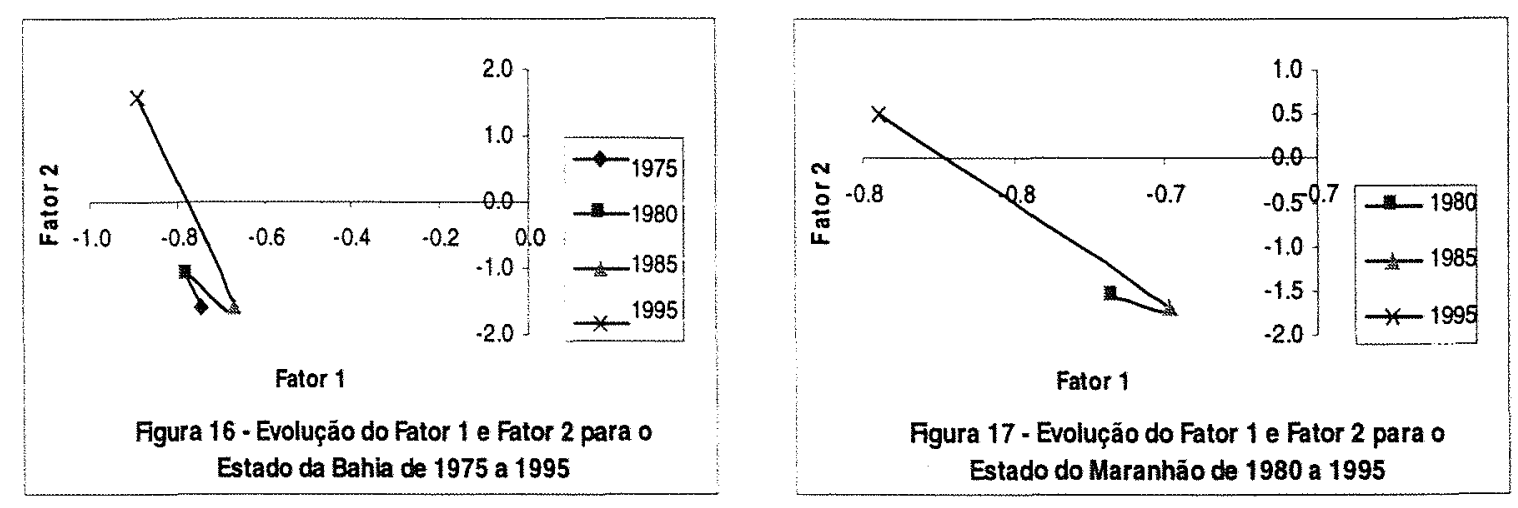
As Figuras 18, 19, 20 e 21 expõem a evolução de F1 (importância da lavoura de soja e capacidade instalada de processamento no estado) e F3 (utilização de crédito para cada hectare da cultura de soja) para a Região Tradicional. Os valores desses dois fatores seguem na mesma direção, diminuindo de 1975 a 1995. Como observado isto ocorreu em função da expansão da lavoura da soja para a região dos cerrados (o que diminuiu o F1) e pelo comportamento da política de crédito rural (diminuindo o F3).
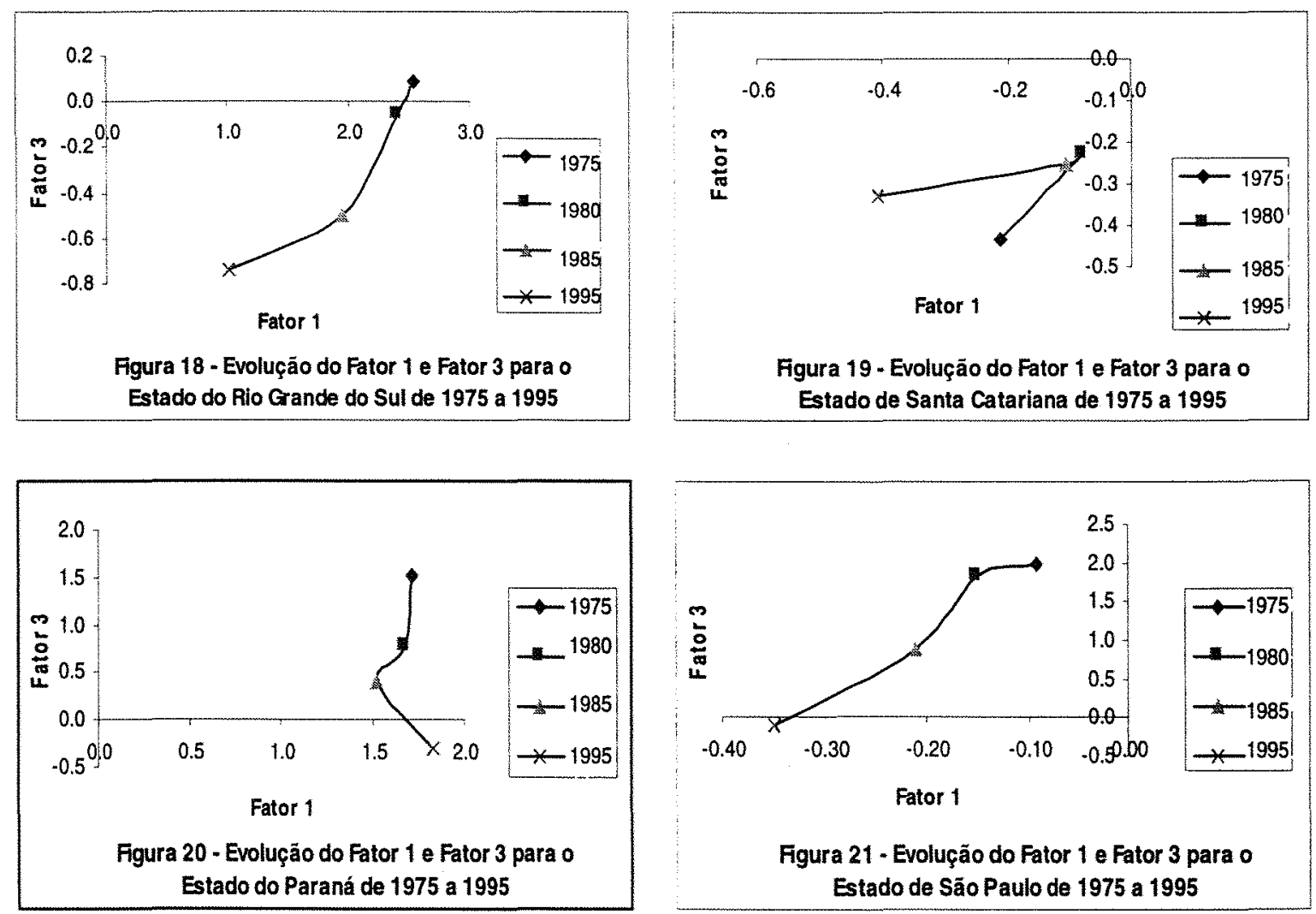

A Região Centro-Oeste e Minas Gerais apresentou comportamento no sentido oposto para os mesmos fatores (F1 e F3). Isso deve-se em função da aceleração do desenvolvimento da cultura da soja nessa região na década de 80 (Figuras 22, 23, 24 e 25), que ocorre com menor disponibilidade de crédito oficial. Esta expansão está ocorrendo com recursos próprios dos produtores ou com outras fontes de financiamento. 

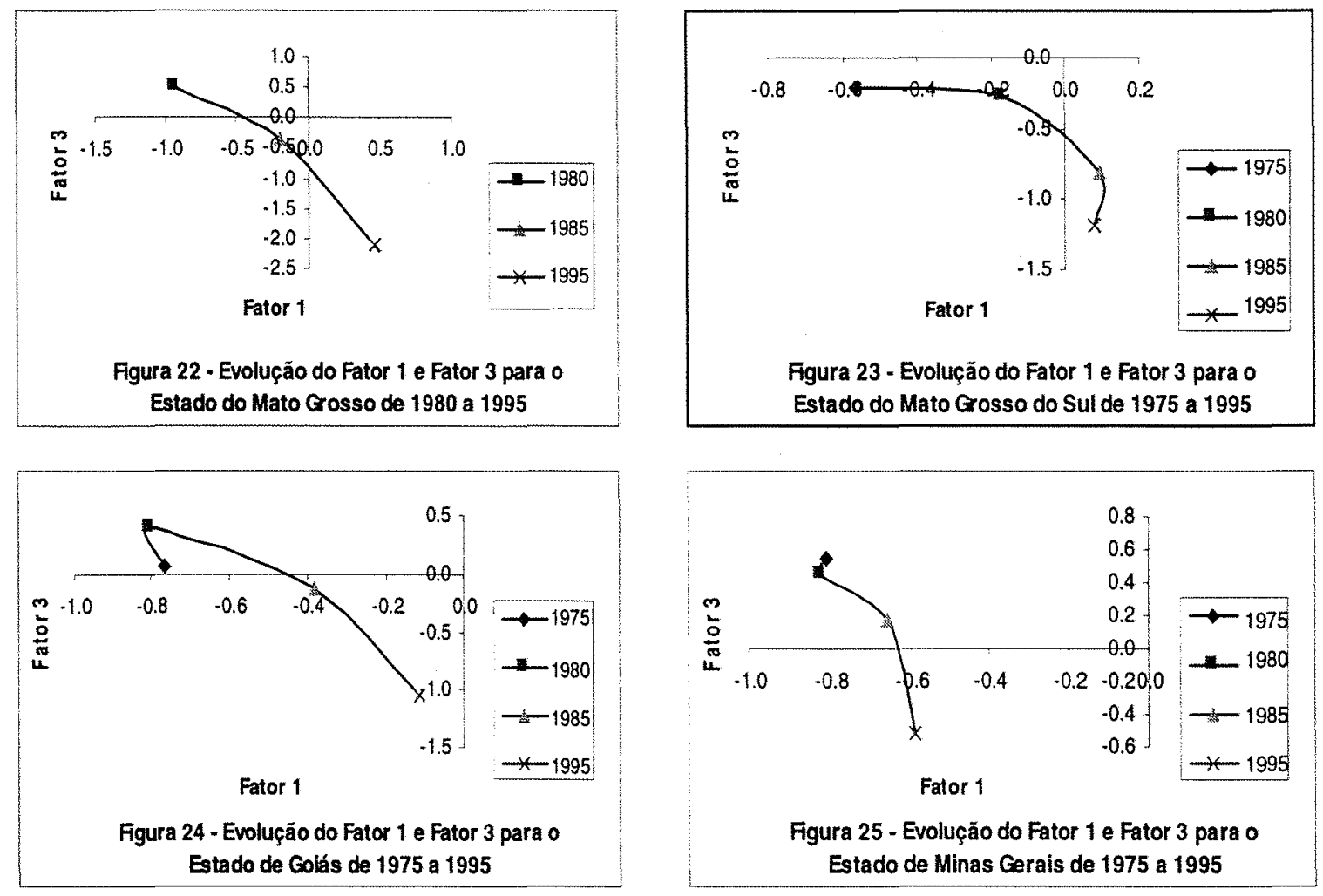

Pode-se observar através das Figuras 26 e 27 o comportamento do Fator 3 para a Região Nordeste. Constata-se que o volume de recursos governamentais por hectare diminuiu desde 1980. Isto ocorre apesar do volume global de crédito destinado ao desenvolvimento da cultura da soja ter aumentado até 1985, com reduções até 1995. Não obstante, o crescimento da lavoura foi maior que o crescimento do volume de crédito (ver Tabela A7 no Anexo). Em outros estados o volume de crédito diminuiu a partir de 1980.
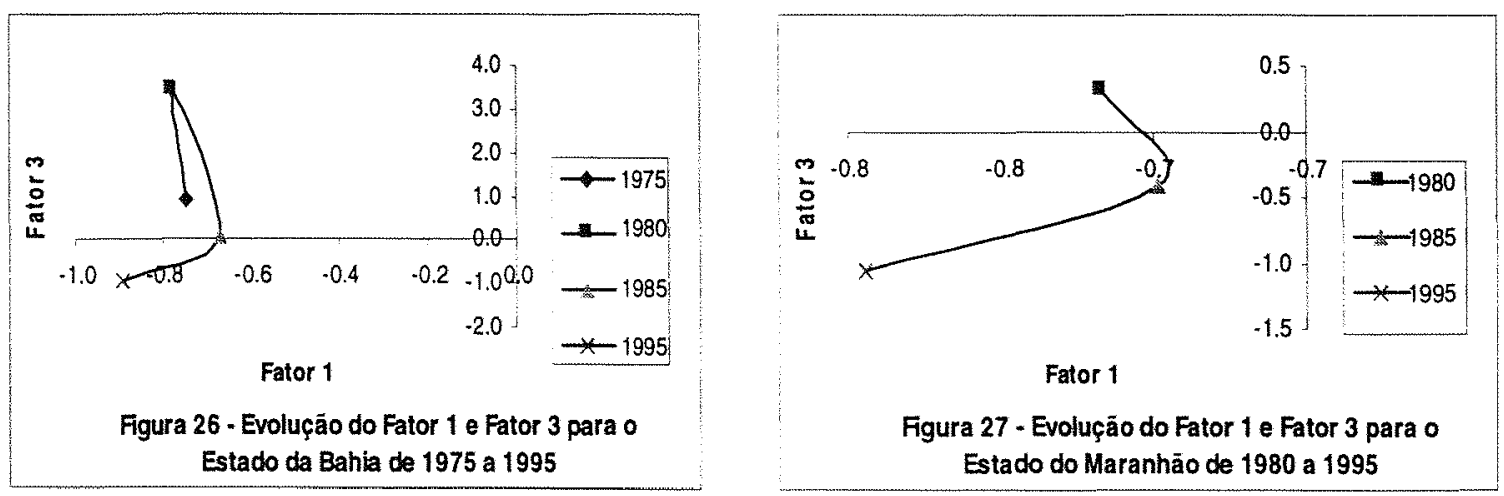
Observa-se pelos resultados encontrados que não há associação relevante entre utilização de crédito para lavoura de soja (variável 8) e indicadores de modernização (variáveis 1, 2 e 3, principalmente). Os coeficientes de correlação entre os pares dos indicadores 8 e 1,8 e 2 , e 8 e 3 são, respectivamente, $-0,278,-0,260$ e $-0,122$. Através das Figuras 28, 29, 30 e 31 verifica-se o comportamento dos Fatores 2 e 3 na Região Tradicional. Pode-se constatar que nesta região, mesmo com reduções na intensidade de crédito por hectare de soja aconteceu com o aumento da modernização da lavoura de soja, associada ao aumento do tamanho médio da lavoura, de 1975 a 1995.
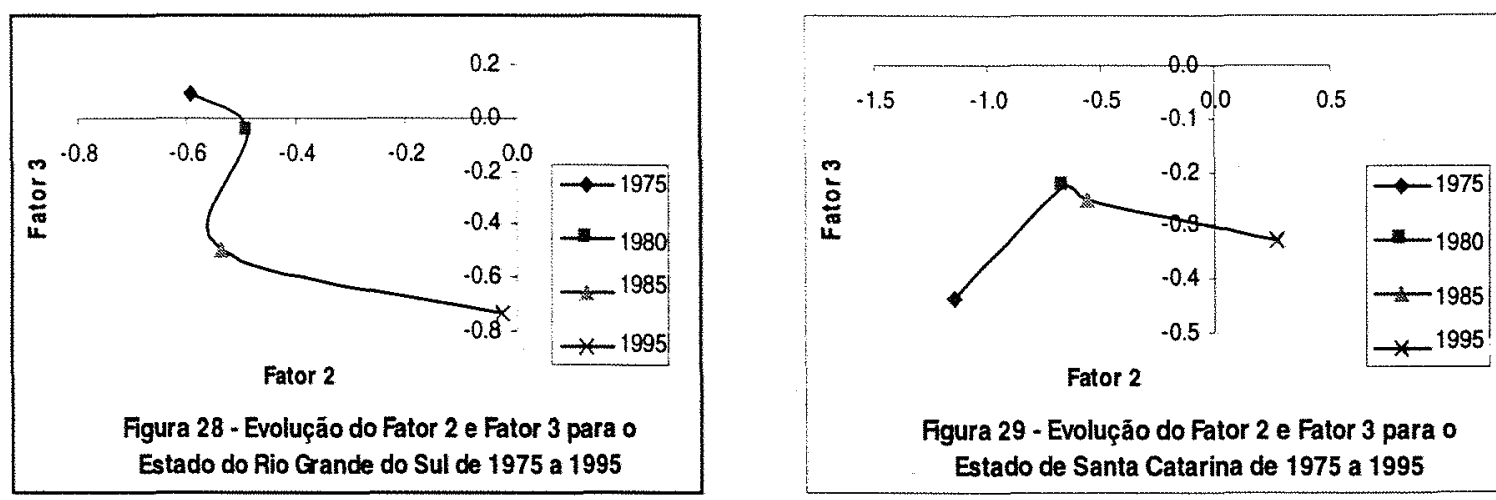

Estado do Rio Grande do Sul de 1975 a 1995

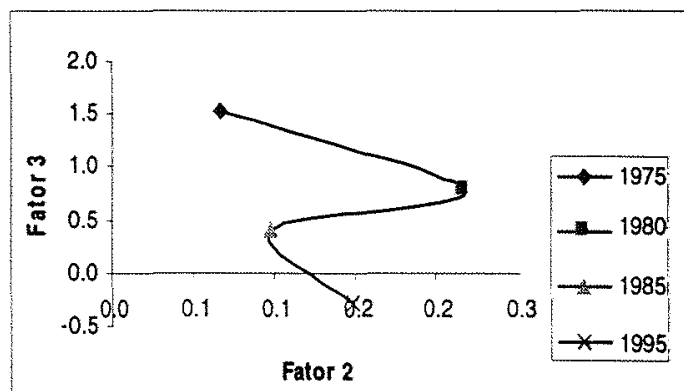

Figura 30 - Evoluçāo do Fator 2 e Fator 3 para o Estado do Paraná de 1975 a 1995

Figura 29 - Evolução do Fator 2 e Fator 3 para 0 Estado de Santa Catarina de 1975 a 1995

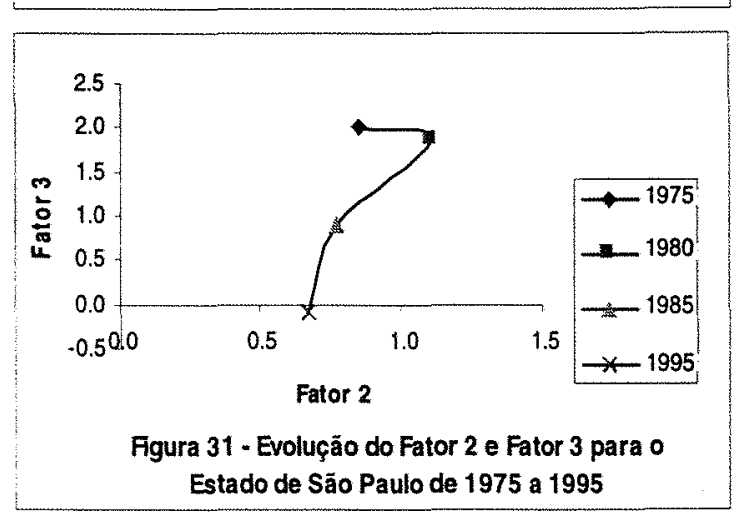

Na Região Centro-Oeste e Minas Gerais, a redução do Fator 3 ocorre em menor intensidade até 1980, apresentando grandes reduções após esse ano, principalmente a partir de 1985. O maior incremento na modernização técnica foi no período 1975/80, apresentando menor ritmo de modernização para 1980/85 e 1985/95, com retrocesso em Goiás e principalmente em Minas Gerais (ver Figuras 32, 33, 34 e 35). 

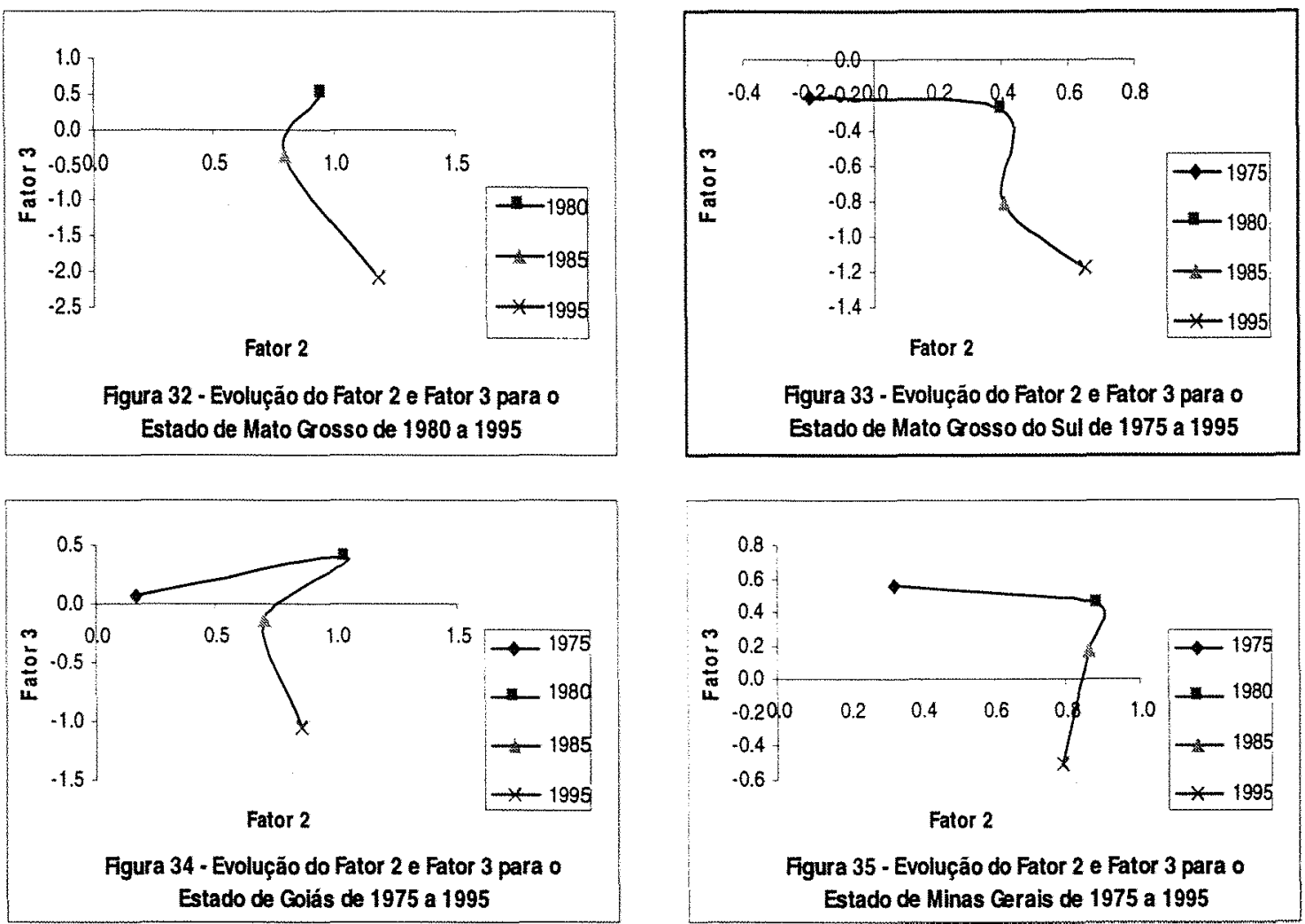

Em função de a maior expansão da soja na Região Nordeste ser a partir de 1985, verificou-se o sentido oposto no comportamento dos Fatores 2 e 3 apenas para o período 1985 a 1995. O grande aumento da modernização ocorre apesar da recente expansão da soja para essa região. Isto porque a cultura da soja já se desenvolveu com grande utilização de tecnologia. O período que ocorre a maior expansão da cultura da soja nesta região é o mesmo período marcado pela redução dos recursos governamentais destinados à agricultura como um todo.
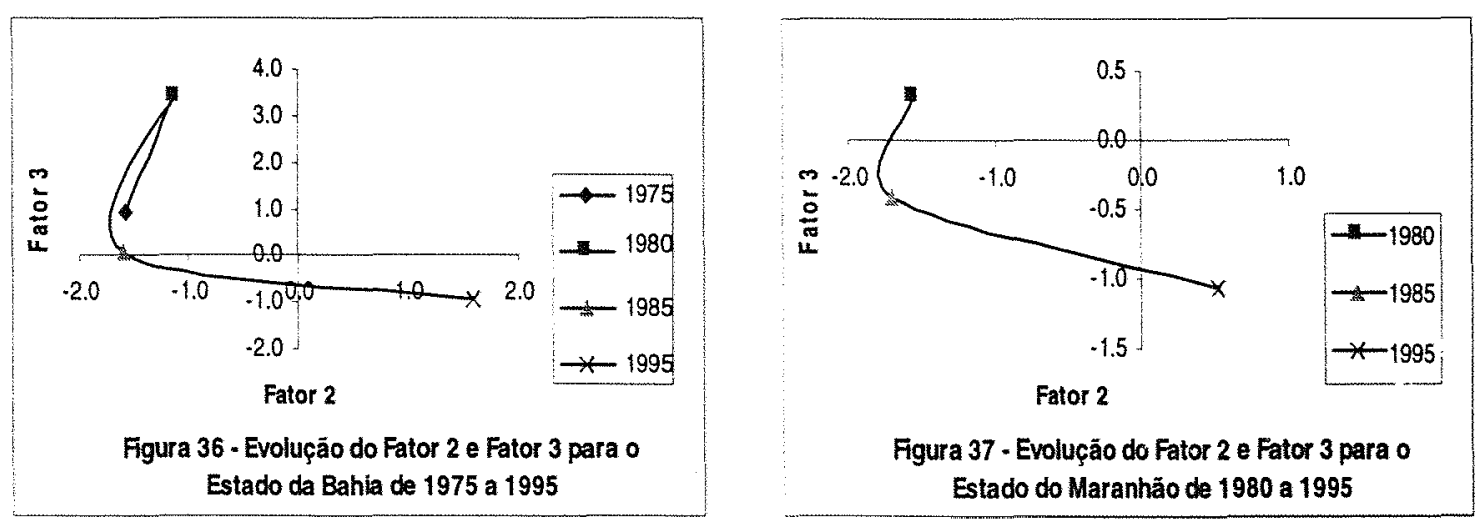
Confirmando os resultados constatados nas Figuras 28 a 37, tem-se que as correlações entre as variações do crédito por hectare e as variações na produtividade da soja para os períodos de 1975/80, 1980/85 e 1985/95 são respectivamente, 0,397, 0,166 e $-0,167$. Esses resultados indicam que os acréscimos de produtividade das lavouras de soja estão ocorrendo por fatores outros do que o incremento de crédito oficial. Entre esses outros fatores pode-se citar a adaptação da tecnologia disponível às diferentes condições edafo-climáticas das regiões sojicultoras.

Para comparar atualmente os indicadores referentes à lavoura da soja entre as regiões de cultivo, considerou-se os valores do Fator 1 e Fator 2, que representam a maior parte da variância total dos indicadores, para o ano de 1995 (ver Figura 38).

Pode-se observar que, apesar da cultura da soja ter se desenvolvido diferentemente entre as regiões do Brasil, os estados que fazem parte de cada região de cultivo desta oleaginosa também encontram-se com níveis de modernização desiguais.

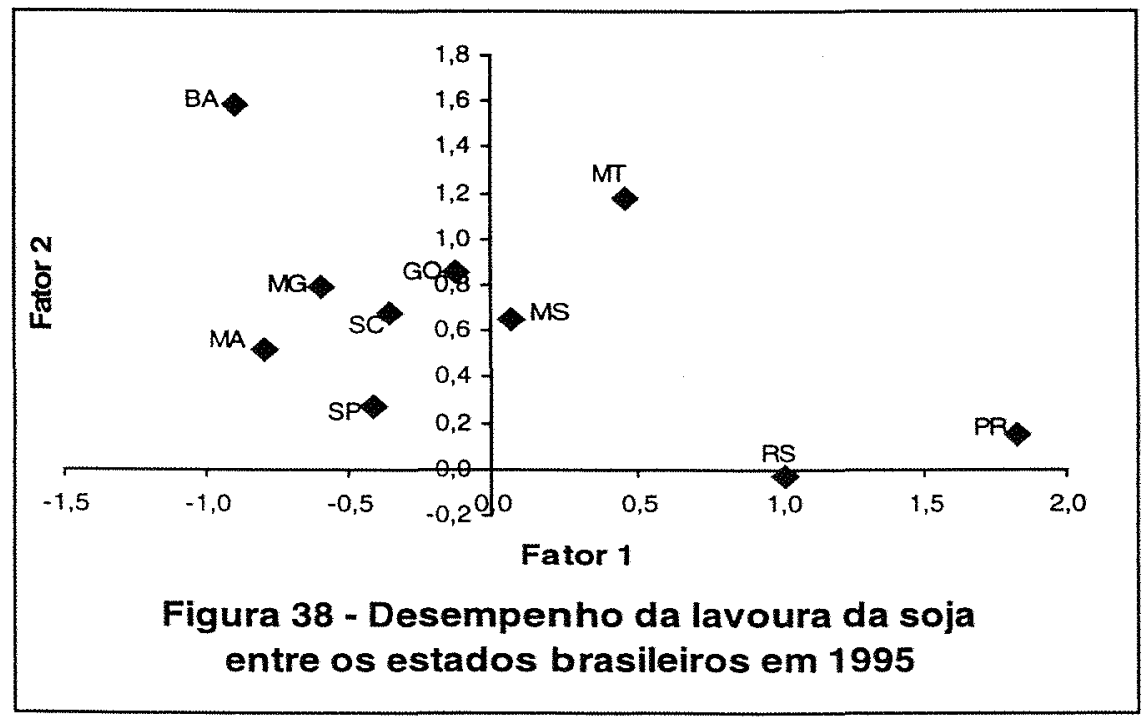

No quadrante que expõe os valores positivos para F1 e F2 se concentram os principais estados produtores de soja do Brasil. Observa-se que tanto a importância da lavoura e capacidade de processamento da soja quanto o nível de modernização tecnológica vinculado com o tamanho da lavoura e participação das indústrias na 
comercialização da soja são elevados. Destacam-se neste grupo os Estados do Mato Grosso e Mato Grosso do Sul que apresentam um grau relativamente elevado da modernização da cultura, mesmo não apresentando valores elevados de F1. O Estado do Rio Grande do Sul, apesar de apresentar um bom desempenho da evolução do F2 no período analisado, é o estado que expressa os menores níveis de modernização da lavoura no Brasil (conforme os valores de F2).

Os demais estados produtores de soja encontram-se no quadrante com valores positivos para F2 e negativos para F1, ou seja, a lavoura da soja possui níveis satisfatórios de modernização tecnológica, apesar da baixa concentração da lavoura e da capacidade instalada de processamento. Os estados em que essas características são mais acentuadas são a Bahia e o Maranhão, em que a expansão da cultura da soja se desenvolveu mais recentemente e com grande utilização de tecnologia, e o Estado de Minas Gerais.

Percebe-se que os estados da Região Tradicional são os que apresentam os menores níveis de modernização perante os demais estados, apesar da evolução positiva do F2 para os Estados do Rio Grande do Sul e Santa Catarina entre 1975 e 1995. Isto pode ser explicado pela menor intensidade no uso de insumos modernos (compare as Tabelas 7 e 8) e principalmente pela menor produtividade (compare as Figuras 5 e 6 ) em relação à Região Centro-Oeste. Em parte, isto surge devido as diferentes condições edafo-climáticas dessas regiões.

Em síntese, ao analisar todos os estados pertencentes às regiões de cultivo da soja, evidencia-se os diferentes níveis de modernização tecnológica em que se encontram as lavouras da soja. Isto sem dúvida, associa-se com suas diferentes condições edafo-climáticas, disponibilidade de terras e infra-estrutura dos estados. 


\section{CONCLUSÕES}

No presente trabalho verificou-se, através da análise tabular e gráfica, as características distintas entre as regiões produtoras de soja no Brasil no período de 1970 a 1999. Pretendeu-se, também, analisar o grau de modernização da cultura da soja no Brasil, mais especificamente nos estados das Regiões Tradicional, Centro-Oeste e Minas Gerais, e Nordeste, em razão de ter ocorrido a expansão da lavoura da soja em períodos distintos nessas regiões.

A expansão da cultura da soja apresentou três fases de crescimento entre as regiões do Brasil. De 1970 a 1979, houve a expansão na Região Tradicional, onde se iniciou o desenvolvimento do cultivo dessa oleaginosa; de 1980 a 1989 se destacou a expansão para a região dos cerrados, mais especificamente na Região Centro-Oeste e no Estado de Minas Gerais; e, de 1990 a 1999 houve a expansão na Região Nordeste, destacando-se os Estados da Bahia e Maranhão, além da continuidade da expansão nas demais regiões.

Para que o processo de modernização da lavoura da soja pudesse ser mensurado, foram selecionadas variáveis que apresentassem a utilização de tecnologia, a evolução da agroindústria processadora e sua importância na comercialização do grão de soja em cada região, o papel do Estado no fomento ao desenvolvimento da lavoura de soja e a participação da cultura (intensidade de exploração) tanto nos estados quanto no território nacional.

A análise fatorial confirmou a evolução distinta da lavoura da soja nas regiões analisadas no período de 1975 a 1995. A Região Tradicional, mesmo apresentando redução da concentração da lavoura de soja e da capacidade de processamento, em 
conseqüência da expansão da lavoura para as regiões dos cerrados, é, ainda em 1995, a que apresentou maior concentração da cultura e processamento da soja, destacando os Estados do Rio Grande do Sul e do Paraná. No entanto, essa região continuou se modernizando, ou seja, utilizando recursos que propiciassem melhor desempenho da cultura da soja.

A Região Centro-Oeste e Minas Gerais mostrou que a concentração da lavoura e da capacidade de processamento da soja se deu, principalmente entre 1980 e 1985, em razão da grande expansão da lavoura de soja ocorrida na década de 80 seguida da instalação do parque processador da soja. Essa região é a que apresentou os níveis mais altos de modernização, ocorrendo de forma mais intensa no período de 1975 a 1980.

A cultura da soja na Região Nordeste, que se expandiu mais recentemente, apresentou altos níveis de modernização para o ano de 1995.

Um resultado muito interessante da pesquisa foi que a intensidade de crédito por área de soja não esteve associada com a modernização técnica da lavoura, nem mesmo na década de 70 , período que se teve maior quantidade de recursos governamentais destinados ao financiamento agrícola. Então, pode-se concluir que o aumento do rendimento médio da soja foi obtido por outros fatores, podendo citar o desenvolvimento de pesquisas permitindo a expansão da cultura soja através de tecnologia direcionada às várias regiões.

O constatado acima e o conhecimento das disparidades no processo de evolução da lavoura da soja entre as regiões cultivadoras é importante para estabelecer políticas diferenciadas visando aumentar sua produtividade, reduzir custos e melhorar a qualidade do produto ofertado. Isto torna os produtores, de determinado estado, competitivos e também contribui para elevar a renda média dos sojicultores.

Entre estas políticas se destacam a de pesquisa agropecuária e a tributária. A primeira buscando determinar tecnologia adequada às condições edafo-climáticas de cada estado. A política tributária pode ser utilizada para reduzir o custo de insumos 
(fertilizantes e defensivos) onde são mais requisitados e onde têm maior custo (de produção e/ou transporte). 
ANEXO: Indicadores 
A1 - Percentual da área colhida de soja que utilizou adubação e defensivos

\begin{tabular}{|c|c|c|c|c|c|c|}
\hline U.F. & Ano & Área Total & Área adubação & $\%$ & $\begin{array}{c}\text { Ârea } \\
\text { defensivos } \\
\end{array}$ & $\%$ \\
\hline RS & 1975 & 3.195 .977 & 2.327 .111 & 72,8 & 2.323 .021 & 72,7 \\
\hline RS & 1980 & 3.763 .073 & 3.261 .867 & 86,7 & 2.633 .747 & 70,0 \\
\hline RS & 1985 & 3.611 .032 & 3.036 .925 & 84,1 & 2.690 .733 & 74,5 \\
\hline RS & 1995 & 2.403 .615 & 2.212 .815 & 92,0 & 2.067 .691 & 86,0 \\
\hline $\mathrm{SC}$ & 1975 & 263.876 & 90.556 & 34,3 & 65.151 & 24,7 \\
\hline $\mathrm{SC}$ & 1980 & 427.996 & 244.496 & 57,1 & 173.551 & 40,5 \\
\hline $\mathrm{SC}$ & 1985 & 403.530 & 245.925 & 61,0 & 189.000 & 46,8 \\
\hline $\mathrm{SC}$ & 1995 & 167.680 & 160.448 & 95,7 & 153.259 & 91,4 \\
\hline PR & 1975 & 1.615 .302 & 1.174631 & 72,7 & 1.263 .816 & 78,2 \\
\hline PR & 1980 & 2.075 .657 & 1.940 .400 & 93,5 & 1.912 .182 & 92,1 \\
\hline PR & 1985 & 2.079 .973 & 1.972 .173 & 94,8 & 1.933 .720 & 92,9 \\
\hline PR & 1995 & 2.259 .401 & 2.198 .651 & 97,3 & 2.196 .177 & 72,2 \\
\hline SP & 1975 & 348.774 & 344.009 & 98,6 & 334.504 & 95,9 \\
\hline SP & 1980 & 485.512 & 482.962 & 99,5 & 470.750 & 97,0 \\
\hline SP & 1985 & 470.057 & 464.909 & 98,9 & 443.829 & 94,4 \\
\hline SP & 1995 & 396.615 & 394.512 & 99,5 & 381.824 & 96,3 \\
\hline MT & 1975 & 0 & 0 & - & 0 & - \\
\hline MT & 1980 & 56.514 & 55.952 & 99,0 & 46.909 & 83,0 \\
\hline MT & 1985 & 822.821 & 811.192 & 98,6 & 759.063 & 92,3 \\
\hline MT & 1995 & 1.739 .291 & 1.715 .553 & 98,6 & 1.667 .964 & 95,9 \\
\hline MS & 1975 & 121.829 & 92.232 & 75,7 & 107.436 & 88,2 \\
\hline MS & 1980 & 606.998 & 585.303 & 96,4 & 589.322 & 97,1 \\
\hline MS & 1985 & 958.568 & 920.688 & 96,0 & 905.347 & 94,4 \\
\hline MS & 1995 & 746.168 & 729.885 & 97,8 & 723.815 & 97,0 \\
\hline GO & 1975 & 61.905 & 60.496 & 98,3 & 51.269 & 83,3 \\
\hline GO & 1980 & 213.487 & 213.046 & 99,8 & 201.466 & 94,3 \\
\hline GO & 1985 & 599.555 & 596.195 & 99,4 & 574.355 & 95,8 \\
\hline GO & 1995 & 863.422 & 861.441 & 99,8 & 839.600 & 97,2 \\
\hline MG & 1975 & 48.359 & 46.680 & 96,5 & 41.881 & 86,6 \\
\hline MG & 1980 & 146.740 & 145.684 & 99,3 & 139.103 & 94,8 \\
\hline MG & 1985 & 362.730 & 357.946 & 98,7 & 338.908 & 93,4 \\
\hline MG & 1995 & 442.943 & 433.773 & 97,9 & 408.748 & 92,3 \\
\hline BA & 1975 & - & - & - & - & - \\
\hline BA & 1980 & - & - & - & - & - \\
\hline $\mathrm{BA}$ & 1985 & - & - & - & - & - \\
\hline $\mathrm{BA}$ & 1995 & 355.101 & 349.450 & 98,4 & 350.659 & 98,7 \\
\hline MA & 1975 & 0 & 0 & - & 0 & - \\
\hline MA & 1980 & - & - & - & - & - \\
\hline MA & 1985 & - & - & - & - & - \\
\hline MA & 1995 & 62.326 & 55.198 & 88,5 & 53.414 & 85,7 \\
\hline
\end{tabular}

Fonte: Censo Agropecuário de 1975, 1980, 1985 e 1995. 


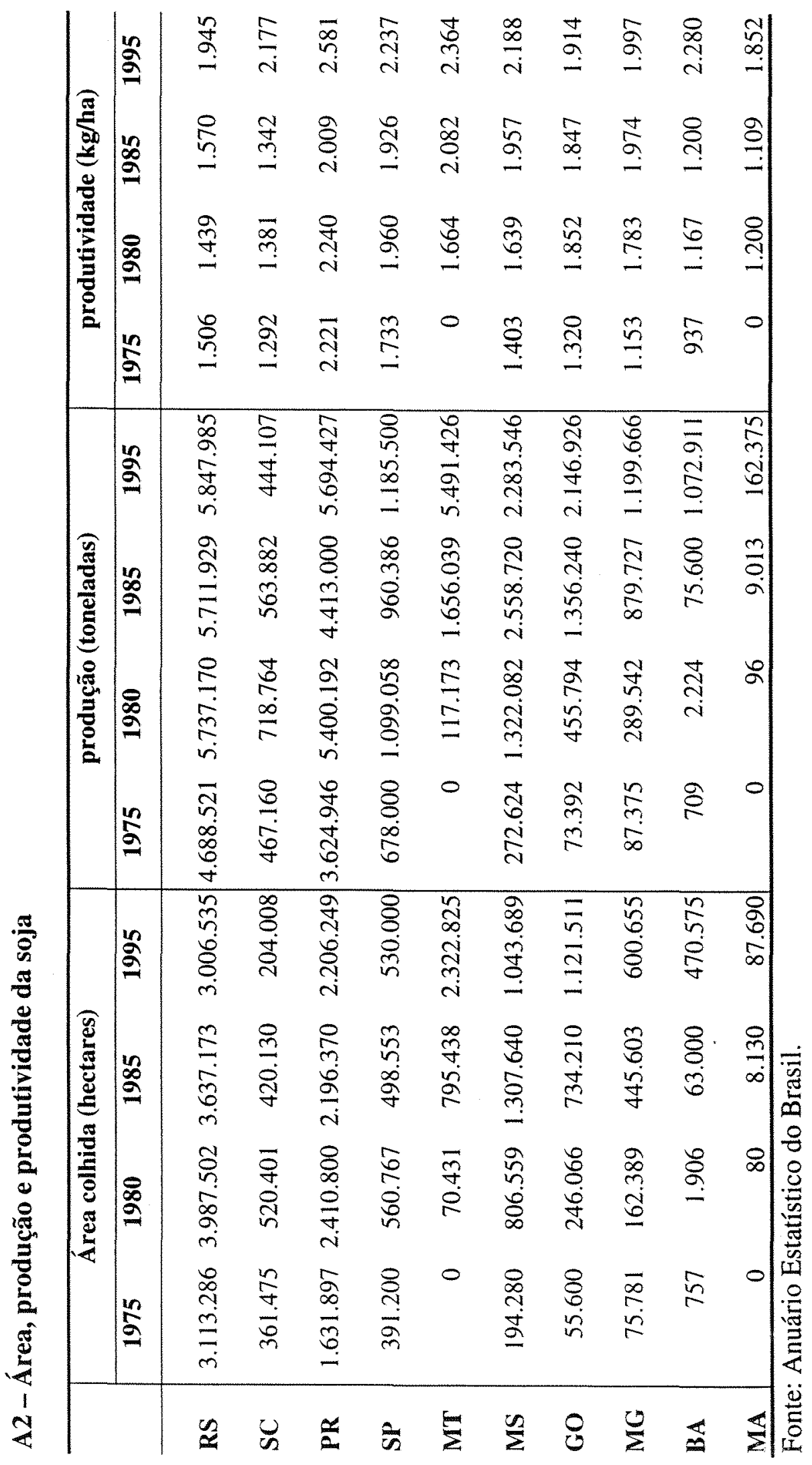




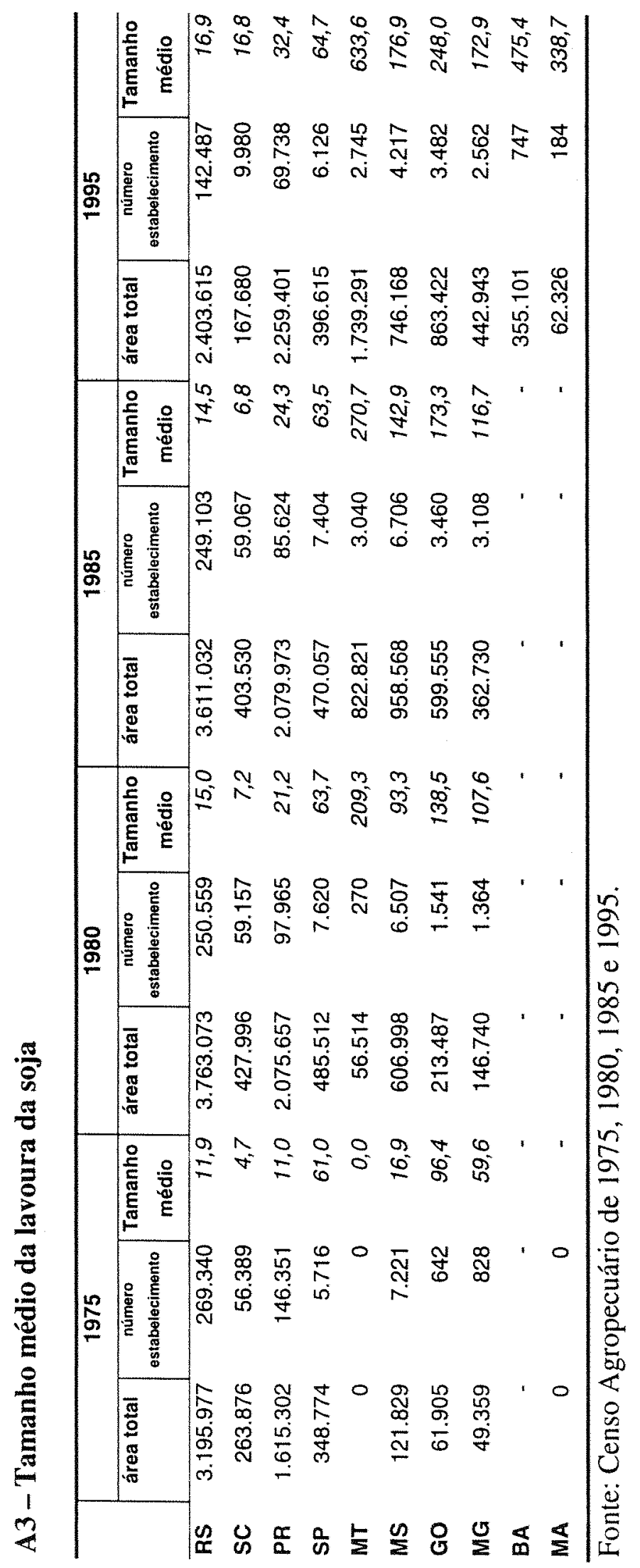


A4 - Percentual da produção de soja entregue à indústria processadora

\begin{tabular}{|c|c|c|c|c|}
\hline U.F. & Ano & Produção (t) & $\begin{array}{c}\text { Produção entregue à } \\
\text { indústria }\end{array}$ & $\begin{array}{l}\text { \% da produção } \\
\text { entregue à indústria }\end{array}$ \\
\hline RS & 1975 & 4.419 .465 & 318.057 & 7,2 \\
\hline RS & 1980 & 5.013 .538 & 634.113 & 12,4 \\
\hline RS & 1985 & 904.728 & 51.455 & 5,7 \\
\hline RS & 1995 & 4.253 .171 & 843.152 & 19,8 \\
\hline SC & 1975 & 270.870 & 20.820 & 7,7 \\
\hline $\mathrm{SC}$ & 1980 & 529.427 & 106.444 & 20,1 \\
\hline $\mathrm{SC}$ & 1985 & 519.730 & 124.414 & 23,9 \\
\hline $\mathrm{SC}$ & 1995 & 408.861 & 68.198 & 16,8 \\
\hline PR & 1975 & 3.103 .049 & 386.001 & 12,4 \\
\hline PR & 1980 & 4.408 .495 & 562.217 & 12,7 \\
\hline PR & 1985 & 4.161 .322 & 502.310 & 12,0 \\
\hline PR & 1995 & 6.046 .293 & 946.749 & 15,6 \\
\hline SP & 1975 & 629.577 & 268.096 & 42,6 \\
\hline SP & 1980 & 958.897 & 538.590 & 56,1 \\
\hline SP & 1985 & 674.910 & 291.479 & 43,2 \\
\hline SP & 1995 & 850.480 & 296.984 & 34,9 \\
\hline MT & 1975 & 0 & 0 & \\
\hline MT & 1980 & 88.852 & 51.997 & 58,5 \\
\hline MT & 1985 & 1.610 .530 & 537.673 & 33,4 \\
\hline MT & 1995 & 4.435 .965 & 1.783 .129 & 40,2 \\
\hline MS & 1975 & 167.981 & 24.533 & 14,6 \\
\hline MS & 1980 & 1.042 .237 & 325.498 & 31,2 \\
\hline MS & 1985 & 1.811 .881 & 458.260 & 25,3 \\
\hline MS & 1995 & 1.796 .994 & 623.917 & 34,7 \\
\hline GO & 1975 & 82.173 & 20.844 & 25,3 \\
\hline GO & 1980 & 368.477 & 224.079 & 60,8 \\
\hline GO & 1985 & 1.157 .704 & 444.405 & 38,4 \\
\hline GO & 1995 & 1.960 .112 & 998.880 & 50,9 \\
\hline MG & 1975 & 47.744 & 18.797 & 39,3 \\
\hline MG & 1980 & 246.764 & 132.684 & 53,7 \\
\hline MG & 1985 & 638.558 & 319.085 & 49,9 \\
\hline MG & 1995 & 864.894 & 407.777 & 47,1 \\
\hline $\mathrm{BA}$ & 1975 & - & - & - \\
\hline BA & 1980 & - & - & - \\
\hline BA & 1985 & - & - & - \\
\hline BA & 1995 & 721.320 & 513.087 & 71,1 \\
\hline MA & 1975 & 0 & 0 & - \\
\hline MA & 1980 & - & - & 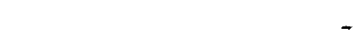 \\
\hline MA & 1985 & - & - & \\
\hline MA & 1995 & 135.123 & 38.706 & 28,6 \\
\hline
\end{tabular}

Fonte: Censo Agropecuário de 1975, 1980, 1985 e 1995. 


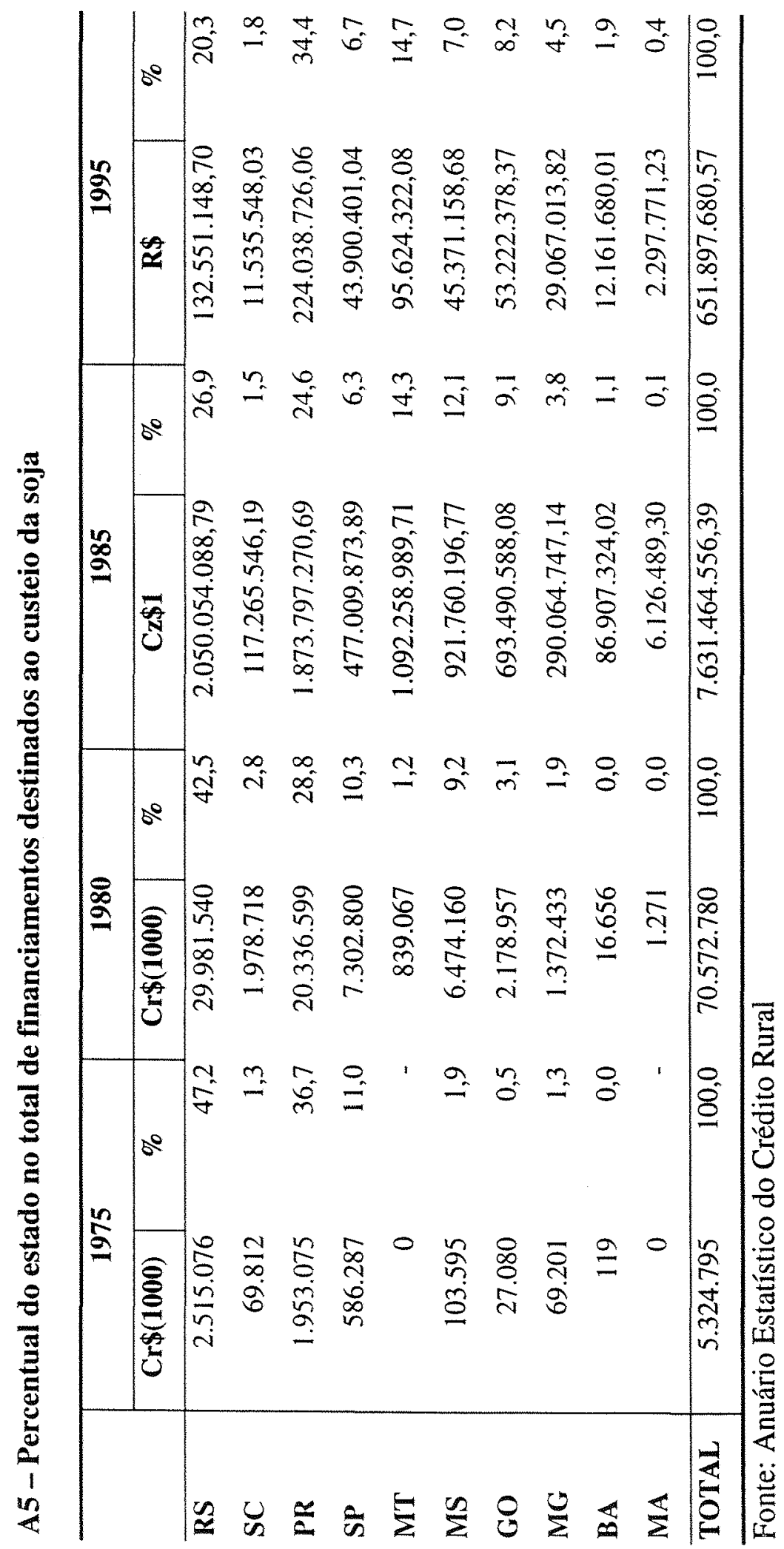




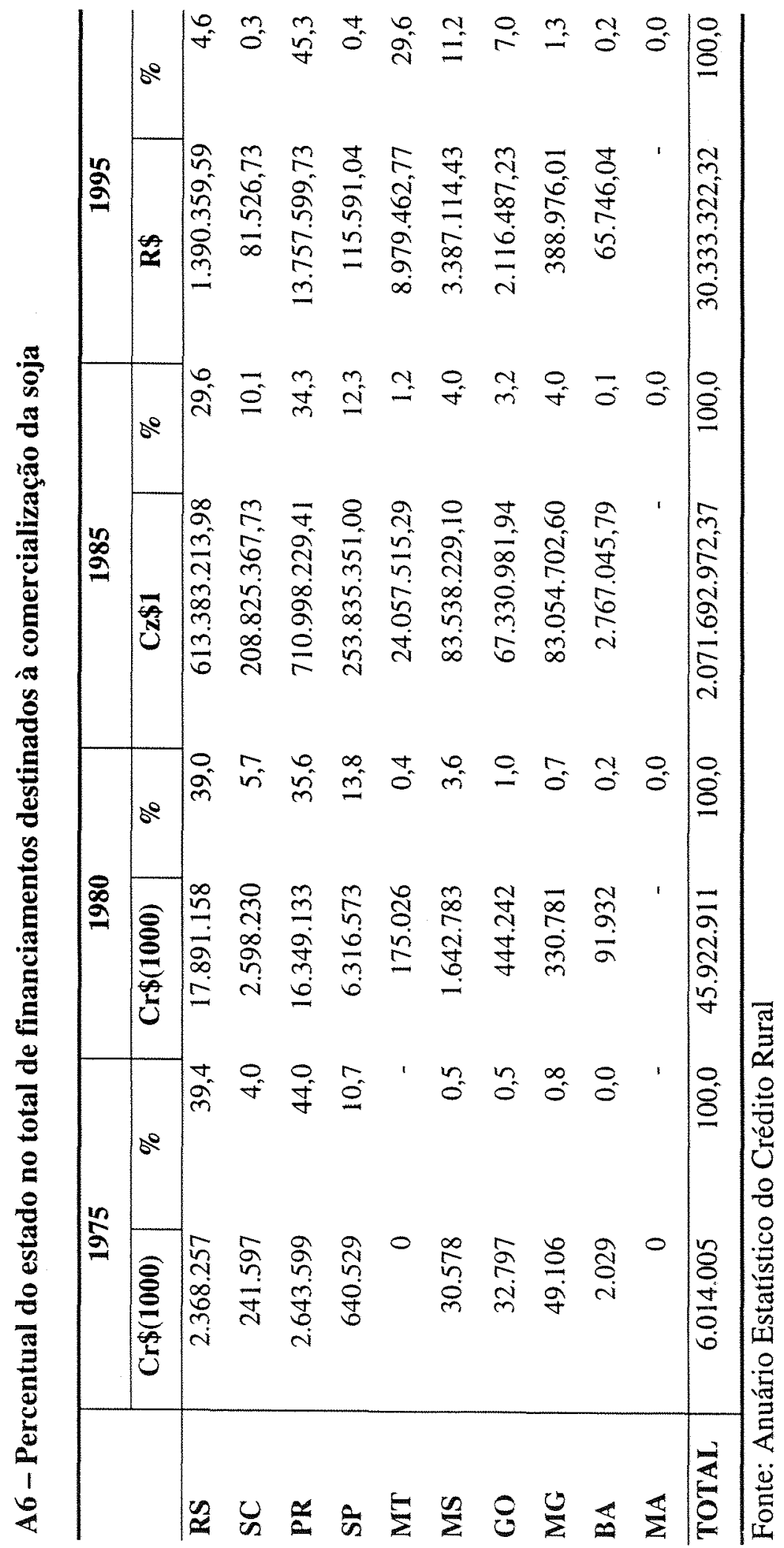


A7 - Total de financiamentos (custeio e comercialização) em relação a área de soja

\begin{tabular}{|c|c|c|c|c|}
\hline U.F. & Ano & Crédito (R\$ ago. 1994) & Área Total (ha) & $\mathrm{R} \$ / \mathrm{ha}$ \\
\hline RS & 1975 & 1.849 .747 .348 & 3.113 .286 & 594,2 \\
\hline RS & 1980 & 2.097.379.978 & 3.987 .502 & 526,0 \\
\hline RS & 1985 & 1.064 .310 .610 & 3.637 .173 & 292,6 \\
\hline RS & 1995 & 114.000 .534 & 3.006 .535 & 37,9 \\
\hline $\mathrm{SC}$ & 1975 & 117.957 .955 & 361.475 & 326,3 \\
\hline $\mathrm{SC}$ & 1980 & 200.523 .461 & 520.401 & 385,3 \\
\hline $\mathrm{SC}$ & 1985 & 130.306 .059 & 420.130 & 310,2 \\
\hline $\mathrm{SC}$ & 1995 & 9.887 .545 & 204.008 & 48,5 \\
\hline PR & 1975 & 1.741.164.394 & 1.631 .897 & 1067,0 \\
\hline PR & 1980 & 1.607 .260 .986 & 2.410 .800 & 666,7 \\
\hline PR & 1985 & 1.032 .885 .314 & 2.196 .370 & 470,3 \\
\hline PR & 1995 & 202.393 .631 & 2.206 .249 & 91,7 \\
\hline SP & 1975 & 464.703 .030 & 391.200 & 1187,9 \\
\hline SP & 1980 & 596.686 .659 & 560.767 & 1064,1 \\
\hline SP & 1985 & 292.046 .043 & 498.553 & 585,8 \\
\hline $\mathrm{SP}$ & 1995 & 37.462 .969 & 530.000 & 70,7 \\
\hline MT & 1975 & 0 & 0 & - \\
\hline MT & 1980 & 44.429 .047 & 70.431 & 630,8 \\
\hline MT & 1985 & 446.080 .521 & 795.438 & 560,8 \\
\hline MT & 1995 & 89.030 .559 & 2.322 .825 & 38,3 \\
\hline MS & 1975 & 50.823 .106 & 194.280 & 261,6 \\
\hline MS & 1980 & 355.616 .342 & 806.559 & 440,9 \\
\hline MS & 1985 & 401.717 .652 & 1.307 .640 & 307,2 \\
\hline MS & 1995 & 41.499 .228 & 1.043 .689 & 39,8 \\
\hline GO & 1975 & 22.680 .682 & 55.600 & 407,9 \\
\hline GO & 1980 & 114.926 .572 & 246.066 & 467,1 \\
\hline GO & 1985 & 304.024 .603 & 734.210 & 414,1 \\
\hline GO & 1995 & 47.100 .113 & 1.121 .511 & 42,0 \\
\hline MG & 1975 & 44.813 .258 & 75.781 & 591,4 \\
\hline MG & 1980 & 74.620 .548 & 162.389 & 459,5 \\
\hline MG & 1985 & 149.098 .681 & 445.603 & 334,6 \\
\hline MG & 1995 & 25.070 .634 & 600.655 & 41,7 \\
\hline $\mathrm{BA}$ & 1975 & 813.636 & 757 & 1074,8 \\
\hline $\mathrm{BA}$ & 1980 & 4.757 .415 & 1.906 & 2496,0 \\
\hline BA & 1985 & 35.833 .914 & 63.000 & 568,8 \\
\hline BA & 1995 & 10.407 .028 & 470.575 & 22,1 \\
\hline MA & 1975 & 0 & 0 & - \\
\hline MA & 1980 & 55.685 & 80 & 696,1 \\
\hline MA & 1985 & 2.448 .147 & 8.130 & 301,1 \\
\hline $\mathrm{MA}$ & 1995 & 1.955 .683 & 87.690 & 22,3 \\
\hline
\end{tabular}

Fonte : Anuário Estatístico do Crédito Rural (crédito);

Anuário Estatístico do Brasil (área colhida de soja). 


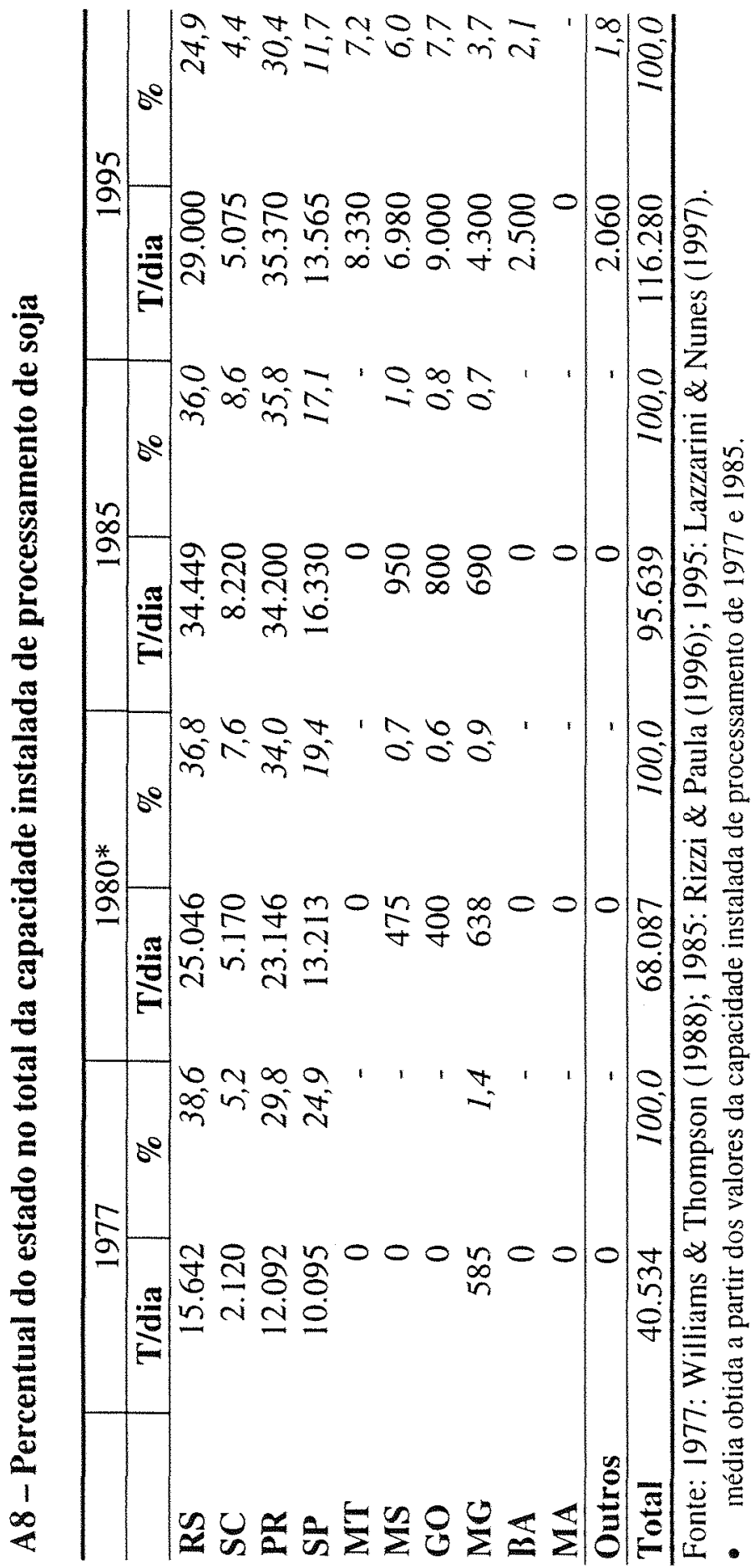


A9 - Proporção da área colhida com soja no total da área destinada à lavouras temporárias e permanentes e no total da área explorada

\begin{tabular}{|c|c|c|c|c|c|c|}
\hline U.F. & Ano & Área Total (ha) & $\begin{array}{c}\text { Lavouras } \\
\text { temporárias e } \\
\text { permanentes }\end{array}$ & $\%$ & $\begin{array}{l}\text { Área explorada } \\
\text { no estado }\end{array}$ & $\%$ \\
\hline RS & 1975 & 3.195 .977 & 5.929 .490 & 53,9 & 21.651 .242 & 14,8 \\
\hline RS & 1980 & 3.763 .073 & 6.682 .613 & 56,3 & 22.065 .163 & 17,1 \\
\hline RS & 1985 & 3.611 .032 & 6.592 .085 & 54,8 & 21.788 .005 & 16,6 \\
\hline RS & 1995 & 2.403 .615 & 5.635 .362 & 42,7 & 19.827 .321 & 12,1 \\
\hline SC & 1975 & 263.876 & 1.434 .433 & 18,4 & 5.466 .562 & 4,8 \\
\hline SC & 1980 & 427.996 & 1.803 .809 & 23,7 & 6.076 .882 & 7,0 \\
\hline $\mathrm{SC}$ & 1985 & 403.530 & 1.868 .832 & 21,6 & 6.247 .773 & 6,5 \\
\hline $\mathrm{SC}$ & 1995 & 167.680 & 1.570 .420 & 10,7 & 5.819 .494 & 2,9 \\
\hline PR & 1975 & 1.615 .302 & 5.627 .538 & 28,7 & 12.973 .631 & 12,5 \\
\hline PR & 1980 & 2.075 .657 & 6.085 .021 & 34,1 & 14.203 .847 & 14,6 \\
\hline PR & 1985 & 2.079 .973 & 6.062 .559 & 34,3 & 14.895 .649 & 14,0 \\
\hline PR & 1995 & 2.259 .401 & 5.100 .509 & 44,3 & 14.572 .534 & 15,5 \\
\hline SP & 1975 & 348.774 & 5.179 .506 & 6,7 & 18.860 .825 & 1,8 \\
\hline SP & 1980 & 485.512 & 5.934 .041 & 8,2 & 18.637 .737 & 2,6 \\
\hline SP & 1985 & 470.057 & 6.541 .801 & 7,2 & 18.720 .258 & 2,5 \\
\hline SP & 1995 & 396.615 & 5.256 .168 & 7,5 & 16.267 .801 & 2,4 \\
\hline MT & 1975 & 0 & 501.267 & - & 18.868 .793 & \\
\hline MT & 1980 & 56.514 & 1.553 .248 & 3,6 & 29.762 .472 & 0,2 \\
\hline MT & 1985 & 822.821 & 2.129 .443 & 38,6 & 32.686 .797 & 2,5 \\
\hline MT & 1995 & 1.739 .291 & 2.943 .709 & 59,1 & 45.937 .488 & 3,8 \\
\hline MS & 1975 & 121.829 & 1.274 .627 & 9,6 & 26.208 .024 & 0,5 \\
\hline MS & 1980 & 606.998 & 1.642 .001 & 37,0 & 27.628 .199 & 2,2 \\
\hline MS & 1985 & 958.568 & 1.902 .970 & 50,4 & 28.330 .571 & 3,4 \\
\hline MS & 1995 & 746.168 & 1.383 .711 & 53,9 & 29.072 .158 & 2,6 \\
\hline GO & 1975 & 61.905 & 2.561 .124 & 2,4 & 38.119 .343 & 0,2 \\
\hline GO & 1980 & 213.487 & 3.226 .269 & 6,6 & 41.615 .653 & 0,5 \\
\hline $\mathrm{GO}$ & 1985 & 599.555 & 2.928 .199 & 20,5 & 26.734 .942 & 2,2 \\
\hline GO & 1995 & 863.422 & 2.174 .853 & 39,7 & 25.426 .855 & 3,4 \\
\hline MG & 1975 & 48.359 & 3.980 .821 & 1,2 & 40.548 .808 & 0,1 \\
\hline MG & 1980 & 146.740 & 4.773 .356 & 3,1 & 41.578 .746 & 0,4 \\
\hline MG & 1985 & 362.730 & 5.340 .110 & 6,8 & 41.510 .709 & 0,9 \\
\hline MG & 1995 & 442.943 & 4.172 .135 & 10,6 & 36.898 .826 & 1,2 \\
\hline BA & 1975 & 757 & 2.663 .581 & 0,0 & 19.849 .960 & 0,0 \\
\hline BA & 1980 & 1.906 & 3.364 .275 & 0,1 & 24.195 .764 & 0,0 \\
\hline BA & 1985 & 63.000 & 4.160 .123 & 1,5 & 26.893 .410 & 0,2 \\
\hline BA & 1995 & 355.101 & 3.889 .829 & 9,1 & 25.516 .159 & 1,4 \\
\hline MA & 1975 & 0 & 1.055 .955 & - & 7.879 .441 & \\
\hline MA & 1980 & 80 & 1.405 .004 & 0,0 & 9.692 .603 & 0,0 \\
\hline MA & 1985 & 8.130 & 1.304 .509 & 0,6 & 9.874 .306 & 0,1 \\
\hline MA & 1995 & 62.326 & 821.827 & 7,6 & 9.008 .154 & 0,7 \\
\hline
\end{tabular}

Fonte : área colhida - Censo Agropecuário do Brasil (exceto estados da BA e MA para os anos de 1975, 1980 e 1985 - Anuário Estatístico do Brasil); área explorada no estado - Censo Agropecuário 
A10 - Participação de cada estado na área colhida com soja no Brasil

\begin{tabular}{|c|c|c|c|c|}
\hline U.F. & Ano & $\begin{array}{c}\text { Área de soja colhida } \\
\text { no Brasil (ha) }\end{array}$ & $\begin{array}{c}\text { Área de soja colhida } \\
\text { no estado (ha) }\end{array}$ & $\%$ \\
\hline RS & 1975 & 5.824 .492 & 3.113 .286 & 53,5 \\
\hline $\mathrm{RS}$ & 1980 & 8.774 .023 & 3.987 .502 & 45,4 \\
\hline RS & 1985 & 10.153 .405 & 3.637 .173 & 35,8 \\
\hline RS & 1995 & 11.675 .005 & 3.006 .535 & 25,8 \\
\hline $\mathrm{SC}$ & 1975 & 5.824 .492 & 361.475 & 6,2 \\
\hline SC & 1980 & 8.774 .023 & 520.401 & 5,9 \\
\hline $\mathrm{SC}$ & 1985 & 10.153 .405 & 420.130 & 4,1 \\
\hline $\mathrm{SC}$ & 1995 & 11.675 .005 & 204.008 & 1,7 \\
\hline PR & 1975 & 5.824 .492 & 1.631 .897 & 28,0 \\
\hline PR & 1980 & 8.774 .023 & 2.410 .800 & 27,5 \\
\hline PR & 1985 & 10.153 .405 & 2.196 .370 & 21,6 \\
\hline PR & 1995 & 11.675 .005 & 2.206 .249 & 18,9 \\
\hline SP & 1975 & 5.824 .492 & 391.200 & 6,7 \\
\hline SP & 1980 & 8.774 .023 & 560.767 & 6,4 \\
\hline SP & 1985 & 10.153 .405 & 498.553 & 4,9 \\
\hline $\mathrm{SP}$ & 1995 & 11.675 .005 & 530.000 & 4,5 \\
\hline MT & 1975 & 5.824 .492 & 0 & - \\
\hline MT & 1980 & 8.774 .023 & 70.431 & 0,8 \\
\hline MT & 1985 & 10.153 .405 & 795.438 & 7,8 \\
\hline MT & 1995 & 11.675 .005 & 2.322 .825 & 19,9 \\
\hline MS & 1975 & 5.824 .492 & 194.280 & 3,3 \\
\hline MS & 1980 & 8.774 .023 & 806.559 & 9,2 \\
\hline MS & 1985 & 10.153 .405 & 1.307 .640 & 12,9 \\
\hline MS & 1995 & 11.675 .005 & 1.043 .689 & 8,9 \\
\hline GO & 1975 & 5.824 .492 & 55.600 & 1,0 \\
\hline GO & 1980 & 8.774 .023 & 246.066 & 2,8 \\
\hline GO & 1985 & 10.153 .405 & 734.210 & 7,2 \\
\hline GO & 1995 & 11.675 .005 & 1.121 .511 & 9,6 \\
\hline MG & 1975 & 5.824 .492 & 75.781 & 1,3 \\
\hline MG & 1980 & 8.774 .023 & 162.389 & 1,9 \\
\hline MG & 1985 & 10.153 .405 & 445.603 & 4,4 \\
\hline MG & 1995 & 11.675 .005 & 600.655 & 5,1 \\
\hline $\mathrm{BA}$ & 1975 & 5.824 .492 & 757 & 0,0 \\
\hline $\mathrm{BA}$ & 1980 & 8.774 .023 & 1.906 & 0,0 \\
\hline $\mathrm{BA}$ & 1985 & 10.153 .405 & 63.000 & 0,6 \\
\hline $\mathrm{BA}$ & 1995 & 11.675 .005 & 470.575 & 4,0 \\
\hline MA & 1975 & 5.824 .492 & 0 & - \\
\hline MA & 1980 & 8.774 .023 & 80 & 0,0 \\
\hline MA & 1985 & 10.153 .405 & 8.130 & 0,1 \\
\hline $\mathrm{MA}$ & 1995 & 11.675 .005 & 87.690 & 0,8 \\
\hline
\end{tabular}

Fonte : Anuário Estatístico do Brasil. 


\section{REFERÊNCIAS BIBLIOGRÁFICAS}

AGUIAR, D.R.D. A indústria de esmagamento de soja no Brasil: mudança estrutural, conduta e alguns indicadores de desempenho. Revista de Economia e Sociologia Rural, v.32, n.1, p.23-46, jan./mar. 1994.

ANUÁRIO ESTATÍSTICO DO BRASIL - vários números.

ANUÁRIO ESTATÍSTICO DO CRÉDITO RURAL, 1995.

ASSOCIAÇÃO BRASILEIRA DAS INDÚSTRIAS DE ÓLEOS VEGETAIS: Capacidade instalada de processamento de oleaginosas. http://www.abiove.com.br (jan. 2000).

ASSOCIAÇÃO BRASILEIRA DAS INDÚSTRIAS DE ÓLEOS VEGETAIS. Dados Estatísticos, 1997.

BARROS, G.S.C.; ARAÚJO, P.F.C. A política de crédito rural no Brasil: perspectivas para os anos 90. Relatório de Resultados $n^{\circ} 11$. Piracicaba (SP) CEPEA/FEALQ, 1991. 17p.

BELIK, W. Um estudo sobre o financiamento da política agroindustrial no Brasil (1965-87). Campinas: UNICAMP/IE, 1994. 58p. (Texto para discussão IE/UNICAMP, n. 35).

BERTRAND, J-P.; LAURENT, C.; LECLERCQ, V. O mundo da soja. São Paulo: HUCITEC, 1987. p.139.

BORRÁS; M.; ALMEIDA, R.; TOLEDO, J.C Caracterização do complexo agroindustrial da soja e da gestão da qualidade no segmento de processamento. São Carlos: UFSC, 1996. 68p. (Relatório de Pesquisa - Iniciação Científica) 
CARVALHO, C. E. L. Mudanças estruturais na agricultura baiana: algumas considerações. Bahia Agrícola, v.2, n.1, p.58-65, nov. 1997.

CASTRO, A. C. A competitividade brasileira nos mercados da soja. In: ENCONTRO NACIONAL DE ECONOMIA, 21, 1993, p.99-115, Belo Horizonte. Anais. Belo Horizonte: ANPEC, 1993.

CENSO AGROPECUÁRIO DO BRASIL - 1975, 1980, 1985 e 1995. Rio de Janeiro (para os estados do RS, SC, PR, SP, MT, MS, GO, MG, BA e MA).

CRÉDITO RURAL - DADOS ESTATÍSTICOS, 1975, 1980 e 1985.

FARINA, E.Q.M; ZYLBERSZTAJN, D. Relações tecnológicas e organização dos mercados do sistema agroindustrial de alimentos. Cadernos de Ciência \& Tecnologia, v.8, n.1/3, p. 9-27, 1991.

FIGUEIREDO, N.M.S. Modernização, distribuição da renda, e pobreza na agricultura brasileira, 1975, 1980, 1985. Piracicaba, 1996. 248p. Tese (Doutorado) - Escola Superior de Agricultura "Luiz de Queiroz", Universidade de São Paulo.

GOMES, M.F.M. Efeitos da expansão da produção de soja em duas regiões do Brasil. Viçosa, 1990. 105p. Tese (Doutorado) - Universidade Federal de Viçosa.

HOFFMANN, R. A dinâmica da modernização da agricultura em 157 microrregiões homogêneas do Brasil. Revista de Economia e Sociologia Rural, v.30, n.4, p.271290, out./dez. 1992.

HOFFMANN, R. Componentes principais e análise fatorial. Piracicaba: ESALQ/USP, 1999. 40p. (Série didática, n.90).

HOFFMANN, R. et al. Inovações tecnológicas e transformações recentes na agricultura brasileira. Piracicaba: FINEP/USP - ESALQ/FEALQ, 1985, v.1. 235p. (Relatório de Pesquisa). 
HOFFMANN, R.; KAGEYAMA, A Modernização da agricultura e distribuição de renda no Brasil. Pesquisa e Planejamento Econômico, v.15, n.1, p.171-208, abr. 1985.

HOFFMANN, R.; KASSOUF, A.L. Modernização e desigualdade na agricultura brasileira. Revista Brasileira de Economia, v.43, n.2, p.273-303, abr./jun. 1989.

IGREJA, A.C.M. Aspectos da reestruturação da cultura da soja no Estado do Paraná. Revista de Economia e Sociologia Rural, v.37, n.3, p.91-115, jul./set. 1999.

KAGEYAMA, A. et al. O novo padrão agrícola brasileiro: do complexo rural aos complexos agroindustriais. UNICAMP, out., 1987. 121p.

KAGEYAMA, A.; SILVA, J.G. Os resultados da modernização agrícola dos anos 70. Estudos Econômicos, v.13, n.3, p.537-559, set./dez. 1983.

KAGEYAMA, A.; SILVEIRA, J.M.J. Agricultura e questão regional. Revista de Economia e Sociologia Rural, v.35, n.2, p.59-89, abr./jun. 1997.

LAZZARINI, S.G.; NUNES, R. Competitividade do sistema agro-industrial da soja. São Paulo: IPEA/PENSA, nov. 1997.

LEVANTAMENTO SISTEMÁTICO DA PRODUÇÃO. Área, produção e produtividade da soja na safra 1998-99. http://www.ibge.gov.br (jun. 2000).

LLANILLO, R.F. Caracterização da estrutura de produção agropecuária do Estado do Paraná. Piracicaba, 1984. 177p. Dissertação (Mestrado) - Escola Superior de Agricultura "Luiz de Queiroz", Universidade de São Paulo.

MAGALHÃES, L.C.G. Competitividade de grãos e de cadeias selecionadas do agribusiness. Texto para discussão - IPEA, n.538, p.93-141, jan.1998.

MARTINS, R. M. A qualidade da soja em grãos e os impactos na cadeia agroindustrial. /Apresentado ao I Curso PENSA de agribusiness, São Paulo, 1995/ 
MEYER, L.F.F.; BRAGA, M.J. O crescimento das desigualdades tecnológicas na agricultura mineira. Revista de Economia e Sociologia Rural, v.36, n.2, p.59-89, abr./jun. 1998.

MUELLER, C.C. Políticas governamentais e expansão recente da agropecuária no Centro-Oeste. Planejamento e Políticas Públicas, n.3, p.45-74, jun. 1990.

NUEVO, P.A.S. A cédula do produto rural (CPR) como alternativa para financiamento da produção agropecuária. Piracicaba, 1996. 109p. Dissertação (Mestrado) - Escola Superior de Agricultura "Luiz de Queiroz", Universidade de São Paulo.

ÓLEOS \& GRÃOS. São Caetano do Sul, n.5, p.12-15, ago./set. 1991.

PAULA, S.R.; FAVARETE FILHO, P. Panorama do complexo soja. BNDES Setorial, Rio de Janeiro, n.8, p.119-152, set. 1998.

RIZZI, A. T.; PAULA, N. M. Indústria agroalimentar e estratégias competitivas recentes: o caso da indústria da soja. Curitiba: UFPR, 1996, 30p. (Síntese do relatório final do projeto de pesquisa "Reestruturação da Indústria Agroalimentar no Brasil e Inserção no Mercado Internacional: uma análise do complexo soja").

ROESSING, A.C.; GUEDES, L.C.A. Aspectos econômicos do complexo soja: sua participação na economia brasileira e evolução na região do Brasil central. In: Cultura da soja nos cerrados. Piracicaba: POTAFOS, 1993. p.1-69.

ROESSING, A.C.; SANTOS, A.B. Descrição sucinta da cadeia produtiva da soja na região sul do Brasil. Informe Econômico CNPSo, v.3, n.1, p.36-56, out.1997.

SHIKIDA, P.F.A. A evolução diferenciada da agroindústria canavieira no Brasil de 1975 a 1995. Piracicaba, 1997. 191p. Tese (Doutorado) - Escola Superior de Agricultura "Luiz de Queiroz", Universidade de São Paulo. 
SHIROTA, R. Crédito rural no Brasil: subsídios, distribuição e fatores associados à oferta. Piracicaba, 1988. 229p. Dissertação (Mestrado) - Escola Superior de Agricultura "Luiz de Queiroz", Universidade de São Paulo.

SHROEDER, R.C. Incentive distortions en commodity markets: lessons from the soybean value chain. Revista Agrosoft, n.9, p.23-29, 1999.

SILVA, A. C. Exportando empregos. Conjuntura Econômica, v.18, n.7, p.13-16, jul. 1998.

SOUZA, I.S.F. Condicionantes da modernização da soja no Brasil. Revista de Economia e Sociologia Rural, v.28, n.2, p.175-212, abr./jun. 1990.

STÜLP, V.J.; PLÁ. J.A. Estudo do setor agroindustrial da soja. Porto Alegre: UFRGS, 1993. 168p.

ZOCKUN, M.H.G.P. A expansão da soja no Brasil: alguns aspectos da produção. São Paulo: IPE-USP, 1980. 243p.

WILLIAMS, G.W.; THOMPSON, R.L. A indústria de soja no Brasil: estrutura econômica e políticas de intervenção do governo no mercado. Coleção Análise e Pesquisa, v.34, p.11-33, abr. 1988. 


\section{APÊNDICE 1}

Correlações entre os indicadores utilizados na Análise Fatorial 


\section{Correlações}

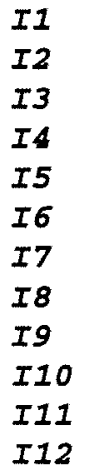

II

I2

IA

I5

I6

I7

I10

I11

$I 12$
$I 1$

I2
1.00000
0.98335
0.77583
0.44058
0.72724
0.30705
0.25030
$-0.27841$
0. 28147
0.40659
0.23967
0.26909
0.98335
1. 00000
0.77761
0. 46172
0.72534
0.28812
0.22143
$-0.26025$
0.25479
0.38567
0.18814
0.25562

13
0.77583
0.77761
1. 00000
0.45136
o. 52842
o. 36891
0.37170
$-0.12216$
0.32547
0.44624
0.31461
0.27677

$I A$

0.44058
0.46172
0.45136
1.00000
0.61762
-0.11949
-0.07623
-0.30839
-0.27274
0.21272
-0.24399
-0.08503

I10

0.40659

0.38567

0.44624

0. 21272

$-0.06687$

0.74132

0.67169

$-0.23956$

0.57899

1. 00000

0. 72378

0.78930
I5

0.72724

0.72534

0.52842

0.61762

1. 00000

$-0.19969$

$-0.20663$

$-0.16837$

$-0.19533$

$-0.06687$

$-0.30237$

$-0.22034$

$I 11$

0.23967

0.18814

0.31461

$-0.24399$

$-0.30237$

0.90269

0.87614

$-0.04954$

0.91376

0.72378

1. 00000

0.89517
I 6

0.30705

0. 28812

0.36891

$-0.11949$

$-0.19969$

1. 00000

0.91133

0.04627

0.88768

0.74132

0.90269

0.94945

$I 12$

0.26909

0.25562

0.27677

$-0.08503$

$-0.22034$

0.94945

0.84072

$-0.01785$

0.85501

0.78930

0.89517

1. 00000 


\section{APÊNDICE 2}

Resultados da análise fatorial utilizando dados para cada ano 
Tabela 2.1 Valores das raízes características em 1975

\begin{tabular}{lllll}
\hline \multicolumn{1}{c}{ Itens } & Fator 1 & Fator 2 & Fator 3 & Fator 4 \\
\hline Raiz característica & 6,7499 & $\mathbf{3 , 6 7 9 3}$ & 0,8585 & 0,3166 \\
Diferença & 3,0707 & 2,8207 & 0,5420 & 0,1397 \\
Proporção & 0,5625 & 0,3066 & 0,0715 & 0,0264 \\
Cumulativa & 0,5625 & $\mathbf{0 , 8 6 9 1}$ & 0,9406 & 0,9670 \\
\hline
\end{tabular}

Fonte: resultados da pesquisa

Tabela 2.2 Cargas fatoriais de 3 fatores e comunalidades na análise dos 12 indicadores relacionados à cultura de soja na Região Tradicional, na Região CentroOeste e Minas Gerais, e na Região Nordeste do Brasil, em 1975

\begin{tabular}{|c|c|c|c|c|}
\hline Variáveis & $\begin{array}{c}\text { Carga } \\
\text { Fatorial para } \\
\text { F1 }\end{array}$ & $\begin{array}{c}\text { Carga } \\
\text { Fatorial para } \\
\text { F2 }\end{array}$ & $\begin{array}{c}\text { Carga } \\
\text { fatorial para } \\
\text { F3 }\end{array}$ & Comunalidade \\
\hline 1. \% da área colhida de soja que utilizou adubação no estado & 0,24851 & 0,95862 & 0,11021 & 0,992854 \\
\hline 2 - \% da área colhida de soja que utilizou defensivos no estado & 0,30691 & 0,91291 & 0,13586 & 0,946052 \\
\hline 3 - Produtividade agrícola da soja no estado(kg/ha) & 0,50767 & 0,56037 & 0,53596 & 0,859000 \\
\hline 4 - Tamanho médio da lavoura de soja no estado & $-0,24289$ & 0,89506 & 0,01597 & 0,860389 \\
\hline $\begin{array}{l}5 \text { - \% da produção de soja no estado entregue à indústria } \\
\text { processadora }\end{array}$ & $-0,16216$ & 0,90706 & 0,24877 & 0,910932 \\
\hline $\begin{array}{l}6 \text { - \% do estado no total de financiamentos destinados ao } \\
\text { custeio da soja }\end{array}$ & 0,97002 & 0,06249 & 0,17257 & 0,974628 \\
\hline $\begin{array}{l}\text { 7-\% do estado no total de financiamentos destinados à } \\
\text { comercialização da soja }\end{array}$ & 0,93704 & 0,04214 & 0,26372 & 0,949375 \\
\hline $\begin{array}{l}8 \text { - Total dos financiamentos de custeio e comercialização da } \\
\text { soja no estado } \div \text { hectares de soja no estado }\end{array}$ & 0,21785 & 0,24107 & 0,93489 & 0,979594 \\
\hline $\begin{array}{l}9 \text { - \% do estado na capacidade instalada de processamento } \\
\text { industrial de soja no Brasil }\end{array}$ & $\mathbf{0 , 8 8 3 4 0}$ & 0,16736 & 0,32322 & 0,912874 \\
\hline $\begin{array}{l}10-\text { Total da área colhida com soja no estado } \div \text { total da área } \\
\text { plantada com lavouras temporárias e permanentes no estado }\end{array}$ & 0,97691 & 0,01692 & $-0,01655$ & 0,954923 \\
\hline $\begin{array}{l}11 \text { - Total da área colhida com soja no estado } \div \text { total da área } \\
\text { explorada no estado }\end{array}$ & 0,97984 & $-0,02874$ & 0,12853 & 0,977425 \\
\hline $\begin{array}{l}12 \text { - Total da área colhida com soja no estado } \div \text { total da área } \\
\text { colhida com soja no Brasil }\end{array}$ & 0,98398 & 0,02743 & 0,02789 & 0,969745 \\
\hline \% da variância & 50.24 & 31,53 & 12,29 & \\
\hline
\end{tabular}

Fonte: Resultados da pesquisa 
Tabela 2.3 Valores das raízes características em 1980

\begin{tabular}{lllll}
\hline \multicolumn{1}{c}{ Itens } & Fator 1 & Fator 2 & Fator 3 & Fator 4 \\
\hline Raiz característica & 6,1931 & $\mathbf{4 , 1 3 0 5}$ & 0,8238 & 0,4267 \\
Diferença & 2,0626 & 3,3067 & 0,3971 & 0,2141 \\
Proporção & 0,5161 & 0,3442 & 0,0687 & 0,0356 \\
Cumulativa & 0,5161 & $\mathbf{0 , 8 6 0 3}$ & 0,9289 & 0,9645 \\
\hline
\end{tabular}

Fonte: resultados da pesquisa

Tabela 2.4 Cargas fatoriais de 3 fatores e comunalidades na análise dos 12 indicadores relacionados à cultura de soja na Região Tradicional, na Região CentroOeste e Minas Gerais, e na Região Nordeste do Brasil, em 1980

\begin{tabular}{|c|c|c|c|c|}
\hline Variáveis & $\begin{array}{c}\text { Carga } \\
\text { Fatorial para } \\
\text { Fl }\end{array}$ & $\begin{array}{c}\text { Carga } \\
\text { Fatorial para } \\
\text { F2 }\end{array}$ & $\begin{array}{c}\text { Carga } \\
\text { fatorial para } \\
\text { F3 }\end{array}$ & Comunalidade \\
\hline I - \% da área colhida de soja que utilizou adubação no estado & 0.24978 & 0,91270 & $-0,29022$ & 0,979639 \\
\hline 2 - \% da área colhida de soja que utilizou defensivos no estado & 0,21841 & 0,93437 & $-0,21145$ & 0,965463 \\
\hline 3 - Produtividade agrícola da soja no estado(kg/ha) & 0,29236 & 0,86726 & 0,15111 & 0,860448 \\
\hline 4 - Tamanho médio da lavoura de soja no estado & $-0,45821$ & 0,73981 & $-0,24207$ & 0,815880 \\
\hline $\begin{array}{l}5 \text { - \% da produção de soja no estado entregue à indústria } \\
\text { processadora }\end{array}$ & $-0,37804$ & 0,87414 & $-0,13794$ & 0,926058 \\
\hline $\begin{array}{l}6 \text { - \% do estado no total de financiamentos destinados ao } \\
\text { custeio da soja }\end{array}$ & 0,97515 & 0,07969 & $-0,07278$ & 0,962569 \\
\hline $\begin{array}{l}\text { 7. \% do estado no total de financiamentos destinados à } \\
\text { comercialização da soja }\end{array}$ & 0,98795 & 0,09111 & 0,06036 & 0,987991 \\
\hline $\begin{array}{l}8 \text { - Total dos financiamentos de custeio e comercialização da } \\
\text { soja no estado } \div \text { hectares de soja no estado }\end{array}$ & -0.16124 & $-0,39545$ & 0,83049 & 0,872086 \\
\hline $\begin{array}{l}\text { 9-\% do estado na capacidade instalada de processamento } \\
\text { industrial de soja no Brasil }\end{array}$ & 0,96539 & 0,11979 & 0,12396 & 0,961691 \\
\hline $\begin{array}{l}10 \text { - Total da área colhida com soja no estado } \div \text { total da área } \\
\text { plantada com lavouras temporárias e permanentes no estado }\end{array}$ & 0,85483 & $-0,01405$ & 0,40204 & 0,892573 \\
\hline $\begin{array}{l}11 \text { - Total da área colhida com soja no estado } \div \text { total da área } \\
\text { explorada no estado }\end{array}$ & 0,97347 & $-0,03729$ & 0,11653 & 0,962619 \\
\hline $\begin{array}{l}12 \text { - Total da área colhida com soja no estado } \div \text { total da área } \\
\text { colhida com soja no Brasil }\end{array}$ & 0.96828 & 0,00632 & 0,15089 & 0,960364 \\
\hline \% da variância & 50,41 & 32,97 & 9,57 & \\
\hline
\end{tabular}

Fonte: Resultados da pesquisa 
Tabela 2.5 Valores das raízes características em 1985

\begin{tabular}{lcccc}
\hline \multicolumn{1}{c}{ Itens } & Fator 1 & Fator 2 & Fator 3 & Fator 4 \\
\hline Raiz característica & 5,8805 & 3,9131 & $\mathbf{1 , 1 2 4 5}$ & 0,8082 \\
Diferença & 1,9674 & 2,7887 & 0,3162 & 0,6959 \\
Proporção & 0,4900 & 0,3261 & 0,0937 & 0,0674 \\
Cumulativa & 0,4900 & 0,8161 & $\mathbf{0 , 9 0 9 8}$ & 0,9772 \\
\hline
\end{tabular}

Fonte: resultados da pesquisa

Tabela 2.6 Cargas fatoriais de 3 fatores e comunalidades na análise dos 12 indicadores relacionados à cultura de soja na Região Tradicional, na Região CentroOeste e Minas Gerais, e na Região Nordeste do Brasil, em 1985

\begin{tabular}{|c|c|c|c|c|}
\hline Variáveis & $\begin{array}{c}\text { Carga } \\
\text { Fatorial para } \\
\text { F1 }\end{array}$ & $\begin{array}{l}\text { Carga } \\
\text { Fatorial para } \\
\text { F2 }\end{array}$ & $\begin{array}{c}\text { Carga } \\
\text { fatorial para } \\
\text { F3 }\end{array}$ & Comunalidade \\
\hline 1 - \% da área colhida de soja que utilizou adubaçāo no estado & 0,34848 & 0,91407 & $-0,03019$ & 0,957873 \\
\hline 2-\% da área colhida de soja que utilizou defensivos no estado & 0,33212 & 0,92621 & $-0,00116$ & 0,968167 \\
\hline 3 - Produtividade agricola da soja no estado(kg/ha) & 0,22623 & 0,93870 & 0,14306 & 0,952811 \\
\hline 4 - Tamanho médio da lavoura de soja no estado & $-0,29896$ & 0,84905 & $-0,08840$ & 0,818074 \\
\hline $\begin{array}{l}5 \text { - \% da produção de soja no estado entregue à indústria } \\
\text { processadora }\end{array}$ & $-0,30275$ & $\mathbf{0 , 8 3 8 3 2}$ & 0,15265 & 0,817741 \\
\hline $\begin{array}{l}6 \text { - \% do estado no total de financiamentos destinados ao } \\
\text { custeio da soja }\end{array}$ & 0,89635 & 0,30355 & $-0,13250$ & 0,913139 \\
\hline $\begin{array}{l}7 \text { - \% do estado no total de financiamentos destinados à } \\
\text { comercialização da soja }\end{array}$ & 0,97267 & $-0,02570$ & 0,07635 & 0,952582 \\
\hline $\begin{array}{l}8 \text { - Total dos financiamentos de custeio e comercialização da } \\
\text { soja no estado } \div \text { hectares de soja no estado }\end{array}$ & $-0,06832$ & 0,17652 & 0,88671 & 0,822084 \\
\hline $\begin{array}{l}9 \text { - \% do estado na capacidade instalada de processamento } \\
\text { industrial de soja no Brasil }\end{array}$ & 0,96997 & $-0,07938$ & 0,13095 & 0,964300 \\
\hline $\begin{array}{l}10-\text { Total da área colhida com soja no estado } \div \text { total da área } \\
\text { plantada com lavouras temporárias e permanentes no estado }\end{array}$ & 0,63647 & 0,39566 & $-0,51602$ & 0,827917 \\
\hline $\begin{array}{l}11 \text { - Total da área colhida com soja no estado } \div \text { total da área } \\
\text { explorada no estado }\end{array}$ & 0,96995 & $-0,04438$ & $-0,17282$ & 0,972638 \\
\hline $\begin{array}{l}12 \text { - Total da área colhida com soja no estado } \div \text { total da área } \\
\text { colhida com soja no Brasil }\end{array}$ & 0,91817 & 0,12124 & $-0,30504$ & 0,950790 \\
\hline \% da variância & 44,57 & 35,85 & 10,57 & \\
\hline
\end{tabular}

Fonte: Resultados da pesquisa 
Tabela 2.7 Valores das raízes características em 1995

\begin{tabular}{lllll}
\hline \multicolumn{1}{c}{ Itens } & Fator 1 & Fator 2 & Fator 3 & Fator 4 \\
\hline Raiz característica & 6,3733 & 2,3779 & $\mathbf{1 , 5 4 4 9}$ & 0,8305 \\
Diferença & 3,9954 & 0,8330 & 0,7144 & 0,3312 \\
Proporção & 0,5311 & 0,1982 & 0,1287 & 0,0692 \\
Cumulativa & 0,5311 & 0,7293 & $\mathbf{0 , 8 5 8 0}$ & 0,9272 \\
\hline
\end{tabular}

Fonte: resultados da pesquisa

Tabela 2.8 Cargas fatoriais de 3 fatores e comunalidades na análise dos 12 indicadores relacionados à cultura de soja na Região Tradicional, na Região CentroOeste e Minas Gerais, e na Região Nordeste do Brasil em 1995

\begin{tabular}{|c|c|c|c|c|}
\hline Variáveis & $\begin{array}{c}\text { Carga } \\
\text { Fatorial para } \\
\text { F1 }\end{array}$ & $\begin{array}{c}\text { Carga } \\
\text { Fatorial para } \\
\text { F2 }\end{array}$ & $\begin{array}{c}\text { Carga } \\
\text { fatorial para } \\
\text { F3 }\end{array}$ & Comunalidade \\
\hline 1 - \% da área colhida de soja que uuilizou adubação no estado & $-0,01460$ & 0,35035 & 0,86885 & 0,877863 \\
\hline 2 - \% da área colhida de soja que utilizou defensivos no estado & -0.38997 & 0,80140 & 0,06929 & 0,799116 \\
\hline 3 - Produividade agrícola da soja no estado(kg/ha) & 0.34997 & $-0,12511$ & 0,79412 & 0,768753 \\
\hline 4 - Tamanho médio da lavoura de soja no estado & 0,21314 & 0,86437 & $-0,04359$ & 0,794459 \\
\hline $\begin{array}{l}\text { 5- \% da produção de soja no estado entregue à indústria } \\
\text { processadora }\end{array}$ & $-0,22778$ & 0,81921 & 0,18374 & 0,756745 \\
\hline $\begin{array}{l}6 \text { - \% do estado no total de financiamentos destinados ao } \\
\text { custeio da soja }\end{array}$ & 0,79652 & $-0,50697$ & 0,29338 & 0,977531 \\
\hline $\begin{array}{l}7 \text { - \% do estado no total de financiamentos destinados à } \\
\text { comercialização da soja }\end{array}$ & 0,77073 & $-0,20652$ & 0,46422 & 0,852181 \\
\hline $\begin{array}{l}8 \text { - Total dos financiamentos de custeio e comercialização da } \\
\text { soja no estado } \div \text { hectares de soja no estado }\end{array}$ & 0.16740 & $-0,68350$ & 0,67606 & 0,952262 \\
\hline $\begin{array}{l}9 \text { - \% do estado na capacidade instalada de processamento } \\
\text { industrial de soja no Brasil }\end{array}$ & 0,62759 & $-0,67953$ & 0,21331 & 0,901128 \\
\hline $\begin{array}{l}10-\text { Total da área colhida com soja no estado } \div \text { total da área } \\
\text { plantada com lavouras temporárias e permanentes no estado }\end{array}$ & 0,87695 & 0,12987 & 0,10803 & 0,797572 \\
\hline $\begin{array}{l}11 \text { - Total da área colhida com soja no estado } \div \text { total da área } \\
\text { explorada no estado }\end{array}$ & 0,70040 & $-0,65499$ & 0,12347 & 0,934816 \\
\hline $\begin{array}{l}12 \text { - Total da área colhida com soja no estado } \div \text { total da área } \\
\text { colhida com soja no Brasil }\end{array}$ & 0,92461 & $-0,16947$ & $-0,00771$ & 0,883689 \\
\hline \% da variância & 34,47 & 32,52 & 18,81 & \\
\hline
\end{tabular}

Fonte: Resultados da pesquisa 


\section{APÊNDICE 3}

Resultados da análise fatorial utilizando dados para cada ano com 96 variáveis e estimativas para os indicadores de adubação, defensivos e tamanho médio da lavoura para a Bahia em 1975 e para a Bahia e Maranhão em 1980 e 1985 
Tabela 3.1 Valores das raízes características em 1975

\begin{tabular}{lcccc}
\hline \multicolumn{1}{c}{ Itens } & Fator 1 & Fator 2 & Fator 3 & Fator 4 \\
\hline Raiz característica & 6,7139 & $\mathbf{3 , 0 4 7 2}$ & 0,8180 & 0,7416 \\
Diferença & 3,6667 & 2,2292 & 0,0764 & 0,3553 \\
Proporção & 0,5595 & 0,2539 & 0,0682 & 0,0618 \\
Cumulativa & 0,5595 & $\mathbf{0 , 8 1 3 4}$ & 0,8816 & 0,9434 \\
\hline
\end{tabular}

Fonte: resultados da pesquisa

Tabela 3.2 Cargas fatoriais de 3 fatores e comunalidades na análise dos 12 indicadores relacionados à cultura de soja na Região Tradicional, na Região CentroOeste e Minas Gerais, e na Região Nordeste do Brasil, em 1975

\begin{tabular}{|c|c|c|c|c|}
\hline Variáveis & $\begin{array}{l}\text { Carga } \\
\text { Fatorial para } \\
\quad \text { F1 }\end{array}$ & $\begin{array}{l}\text { Carga } \\
\text { Fatorial para } \\
\quad \text { F2 }\end{array}$ & $\begin{array}{l}\text { Carga } \\
\text { fatorial para } \\
\text { F3 }\end{array}$ & Comunalidade \\
\hline I - \% da área colhida de soja que utilizou adubação no estado & $-0,08075$ & 0,98441 & 0,08171 & 0,982261 \\
\hline 2 - \% da área colhida de soja que utilizou defensivos no estado & 0.04357 & 0,88688 & 0,18532 & 0,822808 \\
\hline 3 - Produtividade agrícola da soja no estado(kg/ha) & 0,62830 & 0,03426 & 0,54006 & 0,687598 \\
\hline 4 - Tamanho médio da lavoura de soja no estado & 0.49092 & 0,73488 & $-0,02862$ & 0,781873 \\
\hline $\begin{array}{l}5 \text { - \% da produção de soja no estado entregue à indústria } \\
\text { processadora }\end{array}$ & $-0,16839$ & 0,74284 & 0,08557 & 0,587491 \\
\hline $\begin{array}{l}6 \text { - \% do estado no total de financiamentos destinados ao } \\
\text { custeio da soja }\end{array}$ & 0,98106 & $-0,5555$ & 0,15629 & 0,989994 \\
\hline $\begin{array}{l}7 \text { - \% do estado no total de financiamentos destinados à } \\
\text { comercialização da soja }\end{array}$ & 0,93105 & $-0,11977$ & 0,30368 & 0,973423 \\
\hline $\begin{array}{l}8 \text { - Total dos financiamentos de custeio e comercialização da } \\
\text { soja no estado } \div \text { hectares de soja no estado }\end{array}$ & 0.12687 & 0,25958 & 0,88736 & 0,870879 \\
\hline $\begin{array}{l}9 \text { - \% do estado na capacidade instalada de processamento } \\
\text { industrial de soja no Brasil }\end{array}$ & 0,91020 & 0,02122 & 0,33126 & 0,938650 \\
\hline $\begin{array}{l}10 \text { - Total da área colhida com soja no estado } \div \text { total da área } \\
\text { plantada com lavouras temporárias e permanentes no estado }\end{array}$ & 0,92995 & $-0,32829$ & $-0,12532$ & 0,988296 \\
\hline $\begin{array}{l}11 \text { - Total da área colhida com soja no estado } \div \text { total da área } \\
\text { explorada no estado }\end{array}$ & 0,93235 & -0.31829 & 0,11161 & 0,983039 \\
\hline $\begin{array}{l}12-\text { Total da área colhida com soja no estado } \div \text { total da área } \\
\text { colhida com soja no Brasil }\end{array}$ & 0,97497 & $-0,13912$ & $-0,05409$ & 0,972857 \\
\hline \% da variância & 50.26 & 26,35 & 11,55 & \\
\hline
\end{tabular}

Fonte: Resultados da pesquisa 
Tabela 3.3 Valores das raízes características em 1980

\begin{tabular}{lllll}
\hline \multicolumn{1}{c}{ Itens } & Fator 1 & Fator 2 & Fator 3 & Fator 4 \\
\hline Raiz característica & 6,4781 & 2,8913 & $\mathbf{1 , 4 1 2 5}$ & 0,5524 \\
Diferença & 3,5868 & 1,4788 & 0,8601 & 0,2058 \\
Proporção & 0,5398 & 0,2409 & 0,1177 & 0,0460 \\
Cumulativa & 0,5398 & 0,7808 & $\mathbf{0 , 8 9 8 5}$ & 0,9445 \\
\hline
\end{tabular}

Fonte: resultados da pesquisa

Tabela 3.4 Cargas fatoriais de 3 fatores e comunalidades na análise dos 12 indicadores relacionados à cultura de soja na Região Tradicional, na Região CentroOeste e Minas Gerais, e na Região Nordeste do Brasil, em 1980

\begin{tabular}{|c|c|c|c|c|}
\hline Variáveis & $\begin{array}{c}\text { Carga } \\
\text { Fatorial para } \\
\text { F1 }\end{array}$ & $\begin{array}{c}\text { Carga } \\
\text { Fatorial para } \\
\text { F2 }\end{array}$ & $\begin{array}{c}\text { Carga } \\
\text { fatorial para } \\
\text { F3 }\end{array}$ & Comunalidade \\
\hline 1. \% da área colhida de soja que utilizou adubação no estado & $-0,03766$ & 0,97435 & $-0,09781$ & 0,960340 \\
\hline 2- \% da área colhida de soja que utilizou defensivos no estado & $-0,13906$ & 0,92753 & 0,16901 & 0,908216 \\
\hline 3 - Produtividade agrícola da soja no estado $(\mathrm{kg} / \mathrm{ha})$ & 0,31552 & 0,66067 & $-0,51616$ & 0,802465 \\
\hline 4 - Tamanho médio da lavoura de soja no estado & $-0,74049$ & 0,42886 & 0,18662 & 0,767075 \\
\hline $\begin{array}{l}5 \text { - \% da produção de soja no estado entregue à indústria } \\
\text { processadora }\end{array}$ & $-0,34662$ & 0,54246 & $-0,66433$ & 0,855752 \\
\hline $\begin{array}{l}6 \text { - \% do estado no total de financiamentos destinados ao } \\
\text { custeio da soja }\end{array}$ & 0,98212 & 0,08024 & $-0,00677$ & 0,971037 \\
\hline $\begin{array}{l}7 \text { - \% do estado no total de financiamentos destinados à } \\
\text { comercialização da soja }\end{array}$ & $\mathbf{0 , 9 8 7 7 9}$ & 0,06444 & 0,00200 & 0,979880 \\
\hline $\begin{array}{l}8 \text { - Total dos financiamentos de custeio e comercialização da } \\
\text { soja no estado } \div \text { hectares de soja no estado }\end{array}$ & $-0,19208$ & 0,12091 & 0,90705 & 0,874254 \\
\hline $\begin{array}{l}9 \text { - \% do estado na capacidade instalada de processamento } \\
\text { industrial de soja no Brasil }\end{array}$ & 0,96278 & 0,06199 & $-0,01655$ & 0,931066 \\
\hline $\begin{array}{l}10-\text { Total da área colhida com soja no estado } \div \text { total da área } \\
\text { plantada com lavouras temporárias e permanentes no estado }\end{array}$ & 0,86531 & $-0,17801$ & $-0,16366$ & 0,807233 \\
\hline $\begin{array}{l}11 \text { - Total da área colhida com soja no estado } \div \text { total da área } \\
\text { explorada no estado }\end{array}$ & 0,96880 & $-0,18189$ & 0,06653 & 0,976089 \\
\hline $\begin{array}{l}12 \text { - Total da área colhida com soja no estado } \div \text { total da área } \\
\text { colhida com soja no Brasil }\end{array}$ & 0,97351 & $-0,02381$ & $-0,01368$ & 0,948467 \\
\hline \% da variância & 52,73 & 23,49 & 13,63 & \\
\hline
\end{tabular}

Fonte: Resultados da pesquisa 
Tabela 3.5 Valores das raízes características em 1985

\begin{tabular}{lcccc}
\hline \multicolumn{1}{c}{ Itens } & Fator 1 & Fator 2 & Fator 3 & Fator 4 \\
\hline Raiz característica & 5,7755 & 3,1195 & $\mathbf{1 , 3 0 4 0}$ & 1,0900 \\
Diferença & 2,6560 & 1,8155 & 0,2140 & 0,5889 \\
Proporção & 0,4813 & 0,2600 & 0,1087 & 0,0908 \\
Cumulativa & 0,4813 & 0,7412 & $\mathbf{0 , 8 4 9 9}$ & 0,9407 \\
\hline
\end{tabular}

Fonte: resultados da pesquisa

Tabela 3.6 Cargas fatoriais de 3 fatores e comunalidades na análise dos 12 indicadores relacionados à cultura de soja na Região Tradicional, na Região CentroOeste e Minas Gerais, e na Região Nordeste do Brasil, em 1985

\begin{tabular}{|c|c|c|c|c|}
\hline Variáveis & $\begin{array}{c}\text { Carga } \\
\text { Fatorial para } \\
\text { Fl }\end{array}$ & $\begin{array}{c}\text { Carga } \\
\text { Fatorial para } \\
\text { F2 }\end{array}$ & $\begin{array}{c}\text { Carga } \\
\text { fatorial para } \\
\text { F3 }\end{array}$ & Comunalidade \\
\hline 1 - \% da área colhida de soja que utilizou adubação no estado & $-0,00681$ & 0,92383 & 0,30456 & 0,946261 \\
\hline 2 - \% da área colhida de soja que utilizou defensivos no estado & $-0,06795$ & 0,93963 & 0,15103 & 0,910336 \\
\hline 3 - Produtividade agrícola da soja no estado(kg/ha) & 0,34684 & 0,40914 & 0,82631 & 0,970477 \\
\hline 4 - Tamanho médio da lavoura de soja no estado & $-0,60830$ & 0,58438 & $-0,10610$ & 0,722794 \\
\hline $\begin{array}{l}5 \text { - \% da produção de soja no estado entregue à indústria } \\
\text { processadora }\end{array}$ & $-0,22167$ & 0,05713 & 0,94977 & 0,954469 \\
\hline $\begin{array}{l}6 \text { - \% do estado no total de financiamentos destinados ao } \\
\text { custeio da soja }\end{array}$ & 0,95494 & 0,18764 & 0,07834 & 0,953260 \\
\hline $\begin{array}{l}7 \text { - \% do estado no total de financiamentos destinados à } \\
\text { comercialização da soja }\end{array}$ & 0,93308 & $-0,15051$ & $-0,06133$ & 0,897049 \\
\hline $\begin{array}{l}8 \text { - Total dos financiamentos de custeio e comercialização da } \\
\text { soja no estado } \div \text { hectares de soja no estado }\end{array}$ & $-0,10079$ & 0,66985 & 0,00686 & 0,458900 \\
\hline $\begin{array}{l}\text { 9. \% do estado na capacidade instalada de processamento } \\
\text { industrial de soja no Brasil }\end{array}$ & 0,91937 & $-0,12179$ & $-0,12402$ & 0,875452 \\
\hline $\begin{array}{l}10 \text { - Total da área colhida com soja no estado } \div \text { total da área } \\
\text { plantada com lavouras temporárias e permanentes no estado }\end{array}$ & 0,74256 & $-0,05831$ & 0,20980 & 0,598805 \\
\hline $\begin{array}{l}11 \text { - Total da área colhida com soja no estado } \div \text { total da área } \\
\text { explorada no estado }\end{array}$ & 0,95340 & $-0,26135$ & $-0,11241$ & 0,989914 \\
\hline $\begin{array}{l}12 \text { - Total da área colhida com soja no estado } \div \text { total da área } \\
\text { colhida com soja no Brasil }\end{array}$ & 0,95805 & $-0,05467$ & $-0,01956$ & 0,921226 \\
\hline \% da variância & 46,34 & 23.71 & 14.95 & \\
\hline
\end{tabular}

Fonte: Resultados da pesquisa 
Tabela 3.7 Valores das raízes características em 1995

\begin{tabular}{lllll}
\hline \multicolumn{1}{c}{ Itens } & Fator 1 & Fator 2 & Fator 3 & Fator 4 \\
\hline Raiz característica & 6,3718 & 2,3737 & $\mathbf{1 , 5 4 4 7}$ & 0,8356 \\
Diferença & 3,9981 & 0,8290 & 0,7091 & 0,3361 \\
Proporção & 0,5310 & 0,1978 & 0,1287 & 0,0696 \\
Cumulativa & 0,5310 & 0,7288 & $\mathbf{0 , 8 5 7 5}$ & 0,9271 \\
\hline
\end{tabular}

Fonte: resultados da pesquisa

Tabela 3.8 Cargas fatoriais de 3 fatores e comunalidades na análise dos 12 indicadores relacionados à cultura de soja na Região Tradicional, na Região CentroOeste e Minas Gerais, e na Região Nordeste do Brasil em 1995

\begin{tabular}{|c|c|c|c|c|}
\hline Variáveis & $\begin{array}{c}\text { Carga } \\
\text { Fatorial para } \\
\text { F1 }\end{array}$ & $\begin{array}{c}\text { Carga } \\
\text { Fatorial para } \\
\text { F2 }\end{array}$ & $\begin{array}{c}\text { Carga } \\
\text { fatorial para } \\
\text { F3 }\end{array}$ & Comunalidade \\
\hline 1 - \% da área colhida de soja que utilizou adubação no estado & $-0,01553$ & 0,35074 & 0,86834 & 0,877275 \\
\hline 2 - \% da área colhida de soja que utilizou defensivos no estado & $-0,39272$ & 0,79986 & 0,07294 & 0,799335 \\
\hline 3 - Produtividade agrícola da soja no estado(kg/ha) & 0,35279 & $-0,12427$ & 0,79033 & 0,764532 \\
\hline 4- Tamanho médio da lavoura de soja no estado & 0,21328 & 0,86461 & $-0,04701$ & 0,795244 \\
\hline $\begin{array}{l}5 \text { - \% da produção de soja no estado entregue à indústria } \\
\text { processadora }\end{array}$ & $-0,22737$ & 0,81910 & 0,18531 & 0,756961 \\
\hline $\begin{array}{l}6 \text { - \% do estado no total de financiamentos destinados ao } \\
\text { custeio da soja }\end{array}$ & 0,79750 & $-0,50582$ & 0,29276 & 0,977568 \\
\hline $\begin{array}{l}7 \text { - \% do estado no total de financiamentos destinados à } \\
\text { comercialização da soja }\end{array}$ & $\mathbf{0 , 7 7 2 3 3}$ & $-0,20634$ & 0,46084 & 0,851449 \\
\hline $\begin{array}{l}8 \text { - Total dos financiamentos de custeio e comercializaçăo da } \\
\text { soja no estado } \div \text { hectares de soja no estado }\end{array}$ & 0,16914 & $-0,68225$ & 0,67752 & 0,953100 \\
\hline $\begin{array}{l}\text { 9. \% do estado na capacidade instalada de processamento } \\
\text { industrial de soja no Brasil }\end{array}$ & 0,62799 & $-0,67847$ & 0,21480 & 0,900832 \\
\hline $\begin{array}{l}10-\text { Total da área colhida com soja no estado } \div \text { total da área } \\
\text { plantada com lavouras temporárias e permanentes no estado }\end{array}$ & 0,87655 & 0,13052 & 0,10673 & 0,796773 \\
\hline $\begin{array}{l}11 \text { - Total da área colhida com soja no estado } \div \text { total da área } \\
\text { explorada no estado }\end{array}$ & 0,70104 & $-0,65423$ & 0,12336 & 0,934688 \\
\hline $\begin{array}{l}12 \text { - Total da área colhida com soja no estado } \div \text { total da área } \\
\text { colhida com soja no Brasil }\end{array}$ & 0,92403 & $-0,16867$ & $-0,00775$ & 0,882347 \\
\hline \% da variância & 34,54 & 32,45 & 18,75 & \\
\hline
\end{tabular}

Fonte: Resultados da pesquisa 


\section{APÊNDICE 4}

Resultados da análise fatorial utilizando 456 observações e estimativas para os indicadores de adubação, defensivos e tamanho médio da lavoura para a Bahia em 1975 e para a Bahia e Maranhão em 1980 e 1985 
Tabela 4.1 Matriz de dados para a Análise Fatorial, utilizando estimativas para alguns indicadores

\begin{tabular}{|c|c|c|c|c|c|c|c|c|c|c|c|}
\hline \multirow{3}{*}{$\begin{array}{c}\text { Variá } \\
\text { vel }\end{array}$} & \multirow[t]{3}{*}{ Ano } & \multicolumn{10}{|c|}{ Regiōes } \\
\hline & & \multicolumn{4}{|c|}{ Região Tradicional } & \multicolumn{4}{|c|}{ Região Centro-Oeste e Minas Gerais } & \multicolumn{2}{|c|}{ Região Nordeste } \\
\hline & & RS & $\mathrm{SC}$ & PR & $\mathrm{SP}$ & MT & MS & GO & MG & $\mathrm{BA}$ & MA \\
\hline 1 & 75 & 72,8 & 34,3 & 72,7 & 98.6 & - & 75,7 & 98,3 & 96,5 & 80,0 & - \\
\hline I & 80 & 86,7 & 57,1 & 93,5 & 99,4 & 99,0 & 96,4 & 99,8 & 99,3 & 85,0 & $\mathbf{8 0 , 0}$ \\
\hline 1 & 85 & 84,1 & 61,0 & 94,8 & 98,9 & 98,6 & 96,0 & 99.4 & 98,7 & 95,0 & 85,0 \\
\hline I & 95 & 92,0 & 95,7 & 97,3 & 99,4 & 98,6 & 97,7 & 99,7 & 97,9 & 98,4 & 88,5 \\
\hline 2 & 75 & 72,7 & 24,7 & 78,2 & 95,9 & - & 88,2 & 83,3 & 86,6 & 80,0 & - \\
\hline 2 & 80 & 70,0 & 40,5 & 92.1 & 96,9 & 83,0 & 97,1 & 94,3 & 94,8 & 90,0 & 80,0 \\
\hline 2 & 85 & 74,5 & 46,8 & 92,9 & 94,4 & 92,2 & 94,4 & 95,8 & 93,4 & 95,0 & 85,0 \\
\hline 2 & 95 & 86,0 & 91,4 & 72,2 & 96,2 & 95,9 & 96,9 & 97,2 & 92,3 & 98,7 & 85,7 \\
\hline 3 & 75 & 1506.0 & 1292,0 & 2221,0 & 1733,0 & $\overline{-}$ & 1403.0 & 1320.0 & 1153,0 & 937,0 & - \\
\hline 3 & 80 & 1439,0 & 1381,0 & 2240,0 & 1960,0 & 1664,0 & 1639,0 & 1852,0 & 1783,0 & 1167,0 & 1200,0 \\
\hline 3 & 85 & 1570,0 & 1342,0 & 2009.0 & 1926.0 & 2082,0 & 1957,0 & 1847,0 & 1974,0 & 1200,0 & 1109,0 \\
\hline 3 & 95 & {$[945,0$} & 2177,0 & 2581,0 & 2237,0 & 2364,0 & 2188.0 & 1914,0 & 1997,0 & 2280,0 & 1852,0 \\
\hline 4 & 75 & 11,9 & 4,7 & 11.0 & 61,0 & - & 16,9 & 96,4 & 59,6 & 60,0 & - \\
\hline 4 & 80 & 15.0 & 7.2 & 21,2 & 63.7 & 209,3 & 93,3 & 138,5 & 107,6 & 151,3 & 100,0 \\
\hline 4 & 85 & 14,5 & 6,8 & 24,3 & 63.5 & 270,7 & 142,9 & 173,3 & 116,7 & 186,9 & 220,0 \\
\hline 4 & 95 & 16,9 & 16.8 & 32.4 & 64,7 & 633,6 & 176,9 & 248,0 & 172,9 & 475,4 & 338,7 \\
\hline 5 & 75 & 7,2 & 7,7 & 12,4 & 42,6 & - & 14,6 & 25,3 & 39,3 & 0,0 & $\cdot$ \\
\hline 5 & 80 & 12,4 & 20.1 & 12,7 & 56.1 & 58,5 & 31,2 & 60,8 & 53,7 & 0,0 & 0.0 \\
\hline 5 & 85 & 5,7 & 23.9 & 12.0 & 43,2 & 33,4 & 25,3 & 38,4 & 49,9 & 0,0 & 0,0 \\
\hline 5 & 95 & 19,8 & 16,8 & 15.6 & 34,9 & 40,2 & 34,7 & 50,9 & 47,1 & 71,1 & 28,6 \\
\hline 6 & 75 & 47.2 & 1.3 & 36,7 & 11,0 & - & 1,9 & 0,5 & 1,3 & 0,0 & - \\
\hline 6 & 80 & 42,5 & 2,8 & 28,8 & 10,3 & 1,2 & 9,2 & 3,1 & 1,9 & 0,0 & 0.0 \\
\hline 6 & 85 & 26,9 & 1.5 & 24,6 & 6.3 & 14,3 & 12,1 & 9,1 & 3,8 & 1,1 & 0,1 \\
\hline 6 & 95 & 20.3 & 1,8 & 34,4 & 6,7 & 14.7 & 7,0 & 8,2 & 4,5 & 1,9 & 0,4 \\
\hline 7 & 75 & 39,4 & 4,0 & 44,0 & 10.7 & . & 0,5 & 0,5 & 0,8 & 0,0 & - \\
\hline 7 & 80 & 39,0 & 5.7 & 35.6 & 13,8 & 0.4 & 3,6 & 1,0 & 0.7 & 0,2 & 0,0 \\
\hline 7 & 85 & 29,6 & 10,1 & 34,3 & 12,3 & 1,2 & 4,0 & 3,2 & 4,0 & 0,1 & 0,0 \\
\hline 7 & 95 & 4,6 & 0,3 & 45,3 & 0,4 & 29,6 & 11,2 & 7,0 & 1,3 & 0,2 & 0,0 \\
\hline 8 & 75 & 594,2 & 326,3 & 1067,0 & 1187,9 & - & 261,6 & 407,9 & 591,4 & 1074,8 & - \\
\hline 8 & 80 & 526,0 & 385,3 & 666,7 & 1064,1 & 630,8 & 440,9 & 467,1 & 459,5 & 2496,0 & 696,1 \\
\hline 8 & 85 & 292,6 & 310,2 & 470,3 & 585,8 & 560,8 & 307,2 & 414,1 & 334,6 & 568,8 & 301,1 \\
\hline 8 & 95 & 37,9 & 48,5 & 91,7 & 70,7 & 38,3 & 39,8 & 42,0 & 41,7 & 22,1 & 22,3 \\
\hline 9 & 75 & 38,6 & 5,2 & 29,8 & 24,9 & - & 0,0 & 0,0 & 1,4 & 0,0 & - \\
\hline 9 & 80 & 36,8 & 7,6 & 34.0 & 19.4 & 0.0 & 0,7 & 0.6 & 0,9 & 0,0 & 0,0 \\
\hline 9 & 85 & 36,0 & 8,6 & 35,8 & 17,1 & 0,0 & 1,0 & 0,8 & 0.7 & 0,0 & 0,0 \\
\hline 9 & 95 & 24,9 & 4,4 & 30,4 & 11,7 & 7,2 & 6,0 & 7,7 & 3,7 & 2,1 & 0,0 \\
\hline 10 & 75 & 53,9 & 18,4 & 28,7 & 6,7 & $\cdot$ & 9,6 & 2,4 & 1,2 & 0 & . \\
\hline 10 & 80 & 56,3 & 23,7 & 34,1 & 8,2 & 3,6 & 37 & 6,6 & 3,1 & 0,1 & 0 \\
\hline 10 & 85 & 54,8 & 21,6 & 34,3 & 7.2 & 38,6 & 50,4 & 20,5 & 6,8 & 1,5 & 0,6 \\
\hline 10 & 95 & 42,7 & 10,7 & 44,3 & 7,5 & 59,1 & 53,9 & 39,7 & 10,6 & 9,1 & 7,6 \\
\hline 11 & 75 & 14,8 & 4,8 & 12.5 & 1.8 & - & 0,5 & 0,2 & 0,1 & 0,0 & - \\
\hline 11 & 80 & 17,1 & 7,0 & 14,6 & 2,6 & 0,2 & 2,2 & 0,5 & 0,4 & 0,0 & 0,0 \\
\hline 11 & 85 & 16,6 & 6.5 & 14,0 & 2,5 & 2,5 & 3,4 & 2,2 & 0,9 & 0,2 & 0,1 \\
\hline 11 & 95 & 12,1 & 2,9 & 15.5 & 2,4 & 3,8 & 2,6 & 3,4 & 1,2 & 1,4 & 0,7 \\
\hline 12 & 75 & 53,5 & 6,2 & 28,0 & 6,7 & - & 3,3 & 1,0 & 1,3 & 0,0 & - \\
\hline 12 & 80 & 45,4 & 5,9 & 27,5 & 6,4 & 0,8 & 9,2 & 2,8 & 1,9 & 0,0 & 0,0 \\
\hline 12 & 85 & 35,8 & 4,1 & 21,6 & 4,9 & 7,8 & 12,9 & 7,2 & 4,4 & 0,6 & 0,1 \\
\hline 12 & 95 & 25,8 & 1,7 & 18,9 & 4,5 & 19,9 & 8,9 & 9,6 & 5,1 & 4,0 & 0,8 \\
\hline
\end{tabular}

Fonte: Ver Quadro 1

Nota: os números que estão em negrito, indicadores de adubação(1), de defensivos (2) e de tamanho médio da lavoura (4) em 1975, 1980 e 1985 para a Bahia e em 1980 e 1985 para o Maranhão correspondem as estimativas concedidas pela Embrapa Soja - Área de Economia Rural 
Tabela 4.2 Valores das raízes características

\begin{tabular}{lcccc}
\hline \multicolumn{1}{c}{ Itens } & Fator 1 & Fator 2 & Fator 3 & Fator 4 \\
\hline Raiz característica & 5,5263 & 2,9618 & $\mathbf{1 , 2 8 9 1}$ & 0,7396 \\
Diferença & 2,5645 & 1,6727 & 0,5495 & 0,1862 \\
Proporção & 0,4605 & 0,2468 & 0,1074 & 0,0616 \\
Cumulativa & 0,4605 & 0,7073 & $\mathbf{0 , 8 1 4 8}$ & 0,8764 \\
\hline
\end{tabular}

Fonte: resultados da pesquisa

Tabela 4.3 Cargas fatoriais de 3 fatores e comunalidades na análise dos 12 indicadores relacionados à cultura de soja na Região Tradicional, na Região CentroOeste e Minas Gerais, e na Região Nordeste do Brasil - anos selecionados

\begin{tabular}{|c|c|c|c|c|}
\hline Variáveis & $\begin{array}{c}\text { Carga } \\
\text { Fatorial para } \\
\text { FI }\end{array}$ & $\begin{array}{c}\text { Carga } \\
\text { Fatorial para } \\
\text { F2 }\end{array}$ & $\begin{array}{c}\text { Carga } \\
\text { fatorial para } \\
\text { F3 }\end{array}$ & Comunalidade \\
\hline 1 - \% da área colhida de soja que utilizou adubação no estado & $-0,02798$ & 0,94442 & $-0,01639$ & 0,892982 \\
\hline 2 - \% da área colhida de soja que utilizou defensivos no estado & $-0,09793$ & 0,93366 & 0,10194 & 0,891712 \\
\hline 3 - Produtividade agrícola da soja no estado(kg/ha) & 0,40423 & 0,58621 & $-0,48617$ & 0,743400 \\
\hline 4- Tamanho médio da lavoura de soja no estado & $-0,28492$ & 0,46102 & $-0,47824$ & 0,522432 \\
\hline $\begin{array}{l}5 \text { - \% da produção de soja no estado entregue à indústria } \\
\text { processadora }\end{array}$ & $-0,26362$ & 0,61413 & $-0,40112$ & 0,607550 \\
\hline $\begin{array}{l}\text { 6- \% do estado no total de financiamentos destinados ao } \\
\text { custeio da soja }\end{array}$ & 0,97496 & 0,00564 & 0,05837 & 0,953991 \\
\hline $\begin{array}{l}\text { 7- \% do estado no total de financiamentos destinados à } \\
\text { comercialização da soja }\end{array}$ & 0,93371 & $-0,03335$ & 0,03976 & 0,874504 \\
\hline $\begin{array}{l}8 \text { - Total dos financiamentos de custeio e comercialização da } \\
\text { soja no estado } \div \text { hectares de soja no estado }\end{array}$ & $-0,05422$ & 0,01128 & 0,88623 & 0,788471 \\
\hline $\begin{array}{l}9 \text { - \% do estado na capacidade instalada de processamento } \\
\text { industrial de soja no Brasil }\end{array}$ & 0,92934 & $-0,05231$ & 0,16652 & 0,894145 \\
\hline $\begin{array}{l}10 \text { - Total da área colhida com soja no estado } \div \text { total da área } \\
\text { plantada com lavouras temporárias e permanentes no estado }\end{array}$ & 0,77773 & $-0,03361$ & $-0,39485$ & 0,761898 \\
\hline $\begin{array}{l}11 \text { - Total da área colhida com soja no estado } \div \text { total da área } \\
\text { explorada no estado }\end{array}$ & 0,94473 & $-0,23976$ & $-0,01839$ & 0,950343 \\
\hline $\begin{array}{l}\text { 12- Total da área colhida com soja no estado } \div \text { total da área } \\
\text { colhida com soja no Brasil }\end{array}$ & 0,94058 & $-0,10389$ & $-0,01530$ & 0,895718 \\
\hline \% da variância & 44,96 & 23,08 & 13,42 & \\
\hline
\end{tabular}

Fonte: Resultados da pesquisa 